\title{
ARTICLES
}

\section{ENVIRONMENTAL PROTECTION IN THE INFORMATION AGE}

\author{
DANIEL C. EstY*
}

\begin{abstract}
Information gaps and uncertainties lie at the heart of many persistent pollution and natural resource management problems. This article develops a taxonomy of these gaps and argues that the emerging technologies of the Information Age will create new gap-filling options and thus expand the range of environmental protection strategies. Remote sensing technologies, modern telecommunications systems, the Internet, and computers all promise to make it much easier to identify harms, track pollution flows and resource consumption, and measure the resulting impacts. These developments will make possible a new structure of institutional responses to environmental problems including a more robust market in environmental property rights, expanded use of economic incentives and market-based regulatory strategies, improved command-and-control regulation, and redefined social norms of environmental stewardship. Likewise, the degree to which policies are designed to promote information generation will determine whether and how quickly new institutional approaches emerge. While some potential downsides to Information Age environmental protection remain, the promise of a more refined, individually tailored, and precise approach to pollution control and natural resource management looks to be significant.
\end{abstract}

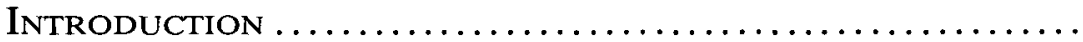

I. Defining the Role of Information in the ENVIRONMENTAL REALM .........................

A. Information Issues in the Environmental

Literature ................................

B. A Deeper Theory of Information ............. 130

1. The Shadow of the Property Versus Liability Rules Debate........................... 130

2. Beneath the Cathedral.................... 131

II. InFORMATION GAP FILLING ................... 140

A. Gap Filling and Institutional Design ........... 141

* Copyright (C) 2004 by Daniel C. Esty. Professor of Environmental Law and Policy, Yale School of Forestry and Environmental Studies and Yale Law School; former Deputy Chief of Staff and Deputy Assistant Administrator for Policy at the U.S. Environmental Protection Agency. Thanks to Farrin Anello, Mark Barnett, Noah Chesnin, Bessie Dewar, Katy Fischer, Brian Fletcher, Phil Fortino, Diane Haar, Gretchen Hoff, Dean Kawamoto, Julia Peck, and Meryl Raymar for research assistance. Thanks to Bishop Grewell, David Victor, Nicole Vickey, Thiru Vignarajah, David Roe, Dennis Hirsch, and Rob Klee, as well as the participants in the Yale Law School faculty seminar, the Yale Environment School faculty seminar, and INSEAD's environmental seminar for comments on prior drafts. Special thanks to Marge Camera. 
B. Rethinking Ends as Well as Means .............. 148

1. Corrective Justice.......................... 150

2. Beyond Externalities ..................... 154

III. The Coming Revolution ..................... 155

A. The Environmental Promise of the Information

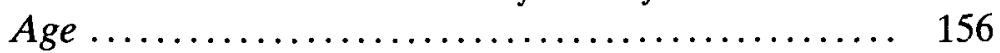

1. Data Collection .......................... 156

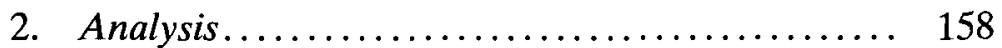

3. Dissemination.......................... 160

B. A Reshaped Environmental Decisionmaking

Context .................................... 162

1. Visibility of Harms ...................... 162

2. Modeling and Prediction ................... 164

3. Quantification........................... 164

4. Transparency and Democracy............... 167

C. New Challenges and Old Problems ............. 171

IV. Institutional Redesign-From Markets to

Hierarchies ................................ 175

A. Revitalizing the Environmental Property Rights

Market................................... 175

1. Search Costs ........................... 175

2. Delineation of Environmental Rights......... 176

3. Valuation and Strategic Behavior............. 178

4. Decollectivization ......................... 179

5. Contracting Beyond Small Numbers .......... 180

B. Court Protected Entitlements .................. 181

C. Command-and-Control Regulation .............. 182

1. Technical Deficiencies.................... 182

2. Cognitive Shortcomings .................. 183

3. Structural or Jurisdictional Mismatches......... 183

4. Public Choice Distortions ................... 184

5. Administrative Inefficiency ................. 186

D. Market-Based Regulation ...................... 187

E. Social Context............................... 189

F. The End of "Do Nothing" ................... 192

1. No Visible Harm Means No Harm ............ 192

2. Limited Resource Pressure ................ 193

3. Assumption of Rough Reciprocity ("Live and Let Live") ................................. 195

4. Small Equals Zero ....................... 196

V. Motivating Information Production ............ 197

A. Driving Environmental Information into the

Decisionmaking Realm. 
B. Critical Environmental Information Does Not

Exist .................................... 198

1. Cost Barriers............................. 198

2. Market Failures .......................... 201

3. Legal and Institutional Failures ............ 203

C. Information Withheld ..................... 207

1. Antagonism Toward Government ........... 207

2. Competitive Positioning .................. 208

CONCLUSION ......................................... 209

\section{INTRODUCTION}

Information issues are central to the challenge of environmental protection. Inadequate information and related transaction costs make Coasean contractual exchanges of environmental rights infeasible in many circumstances. ${ }^{1}$ Information issues are also at the heart of the debate over whether entitlements, including environmental rights, are best protected by property rules or liability rules. ${ }^{2}$ Even as a generation of legal scholars debated the optimal form of tort law over the last fifty years, mounting frustration with the information demands of a tort-based environmental regime ${ }^{3}$ precipitated a shift toward a structure based on statutes and regulations, which incorporated various techniques to "short circuit" the information requirements for environmental decisionmaking. ${ }^{4}$ In recent years, however,

1 See R. H. Coase, The Problem of Social Cost, 3 J.L. \& Econ. 1, 10 (1960) (arguing that, in absence of transaction costs, efficient level of emissions can be negotiated). See generally COASEAN ECONOMICS: LAW AND ECONOMICS AND THE NEW INSTITUTIONAL Economics (Steven G. Medema ed., 1998); Guido Calabresi, The Pointlessness of Pareto: Carrying Coase Further, 100 Y ALE L.J. 1211 (1991) (discussing how transaction costs complicate bargaining); Robert C. Ellickson, The Case for Coase and Against "Coaseanism", 99 YALE L.J. 611 (1989) (noting that Coase recognized effect of transaction costs on exchanges).

2 See Guido Calabresi \& A. Douglas Melamed, Property Rules, Liability Rules, and Inalienability: One View of the Cathedral, 85 HaRv. L. REv. 1089 (1972) (exploring when entitlements should be granted and under what circumstances property, liability, or inalienability rules should be applied). For an overview of the broader Cathedral literature, see infra note 55 .

3 See, e.g., James E. Krier \& Stewart J. Schwab, Property Rules and Liability Rules: The Cathedral in Another Light, 70 N.Y.U. L. Rev. 440, 453-57 (1995) (noting that problems in obtaining and processing information may impede efficient damage calculations by courts).

4 See Robert V. Percival et al., Environmental Regulation: Law, Science, AND Policy 85-95 (4th ed. 2003) (providing comprehensive structural overview of emergence and eventual dominance of statutory environmental law); Richard B. Stewart, $A$ New Generation of Environmental Regulation?, 29 CAP. U. L. REv. 21 (2001) (chronicling and criticizing rise of environmental regulation model). The logic for "short circuiting" information requirements is provided by Diver and others who have contributed to the "optimal specificity" of regulation literature. See infra note 49. 
disappointment has arisen over regulatory failures-often traceable to information gaps-that remain pervasive despite numerous regulatory reform initiatives. ${ }^{5}$

Uncertainty seems to be the hallmark of the environmental domain. Disagreements over how best to cope with information deficits have translated into bitterly partisan and divisive environmental politics and limited progress in recent years in pollution control and natural resource stewardship. Perhaps this picture represents the inescapable reality of the environmental realm.

But imagine instead another world, one where pollution or natural resource use ${ }^{6}$ easily could be traced at low cost. What if each increment of $\mathrm{SO}_{\mathrm{x}}$ or $\mathrm{NO}_{\mathrm{x}}$ emitted from a smokestack could be tracked to where it landed downwind? And what if the "fate and transport" (as an ecological scientist would put it) of nitrogen and phosphorus in runoff from farm fields or suburban lawns easily could be determined? Would things not be different if automobile emissions of volatile organic compounds (VOCs), particulates, and other pollutants could be "tagged" and traced as they flowed from tailpipes to the "receptors" that absorb them? And what if the impacts on the receptors (including people, crops, lakes, and forests) were better understood as a result of advances in epidemiology, risk analysis, and various ecological sciences? Better data on the scope, spread, and effects of environmental harms would not eliminate all of the information gaps that plague environmental policymaking, but such information would open significant new policy options and would alter the framework within which we think about environmental problems.

Such a vision is not so farfetched. Computers, wireless communications, remote sensing, and other technological breakthroughs are reshaping every facet of modern life by vastly increasing our capacity to collect, disseminate, and utilize information. The emergence of these powerful new digital technologies is now broadly evident, and their spread across the economy and society appears inexorable. ${ }^{7}$

5 Criticism of statutory environmental law is legion. For a representative sampling, see generally J. Clarence Davies \& Jan Mazurek, Pollution Control in the United States: Evaluating the System (1998); Economic Analyses at EPA: Assessing Regulatory IMPACT (Richard D. Morgenstern ed., 1997); MARC K. LANDY ET AL., THE Environmental Protection Agency: Asking the Wrong Questions (1990).

6 The environmental realm encompasses a broad array of pollution and natural resource management issues. This Article primarily focuses on pollution control, but its arguments are applicable to the full range of environmental challenges.

7 See Peter Schwartz et al., The Long Boom 26 (1999) (discussing "inevitable" economic and social developments being driven by spread of computers and other Information Age technologies). For additional perspectives, see generally Thomas $\mathrm{H}$. DAVENPORT, INFORMATION ECOLOGY: MASTERING THE INFORMATION AND KNOWLEDGE Environment (1997); Digital Futures: Living in a Dot-Com World (James Wilsdon 
Because information gaps and uncertainties lie at the heart of many persistent pollution and natural resource management problems, technological breakthroughs offer special promise in the environmental domain. As data become easier to analyze and disseminate, and dramatically less costly to acquire and use,$^{8}$ our capacity to identify and solve environmental problems will increase substantially.

While information issues long have played a part in the academic debate over how to refine environmental law, recent scholarship has focused on other matters such as the need for economic incentivebased regulation, public choice failures, cognitive limitations that affect decisionmaking, and questions of federalism and the realignment of environmental regulatory responsibility. ${ }^{9}$

In this Article, I seek to refocus scholarly attention on information failures as a central concern for environmental law and policy. My effort is both descriptive and normative. As a positive matter, environmental decisionmaking critically depends on data and analysis. How we respond to information gaps, in turn, shapes our choices of institutional design for environmental protection. I argue that, as the Information Age changes the context of these choices, important opportunities for improved environmental results are emerging.

Indeed, we stand on the verge of an environmental revolution perhaps as important as that which launched the modern environmental movement four decades ago, ${ }^{10}$ The technological advances of the Information Age provide an opportunity to make environmental protection more data-driven, empirical, and analytically rigorous. The core argument of this Article is that as information gaps become less pervasive, institutional design options for addressing environmental

ed., 2001); The Ecology of the New Economy: Sustainable Transformation of Global Information, Communications and Electronics Industries (Jacob Park \& Nigel Roome eds., 2002) [hereinafter Ecology of THE NEw Economy]; Nigel Roome \& Jacob Park, Global Sustainability and Information Economy: Old Challenges, New Perspectives, 32 GRENNER MGMT. INT'L 24, 25-27 (2000).

8 Cf. William J. Mitchell, E-Topia: "Urban Life, Jim-But Not As We Know IT" 13 (1999) ("Information has become dematerialized and disembodied; it is now whizzing round the world at warp speed, and in cortex-crackling quantities . . . ."); Ira S. Nathenson, Internet Infoglut and Invisible Ink: Spamdexing Search Engines with Meta Tags, 12 HARV. J.L. \& TECH. 43, 43-54 (1998) (describing explosion of information accessible through free online search engines).

9 See infra notes $17-22$.

10 On the rise of the environmental movement of the 1960s and 1970s, see generally Richard N.L. Andrews, Managing the Environment, Managing Ourselves: A History of American Environmental Policy (1999); Philip Shabecoff, A Fierce Green Fire: The American Environmental Movement (1993). For a perspective on the movement's accomplishments and future challenges, see generally JAMES GuSTAVE Speth, Red Sky at Morning: America and the Crisis of the Global Environment (2004). 
problems will expand and we will be able to rethink our regulatory choices. While refined regulatory strategies and structures likely will improve environmental protection broadly, it is important to note that institutional design choices themselves also affect the incentives for data generation. Thus, policies should be constructed to optimize information generation and to ensure that new technologies are deployed and harnessed quickly in the environmental realm.

I unfold the logic and implications of this coming revolution in several stages. Part I surveys the existing "information and environment" literature and concludes that it consistently has underappreciated the wide range of ways that data gaps and knowledge deficiencies affect our strategies for addressing environmental harms. In mapping this terrain, I develop a taxonomy of information needs for environmental decisionmaking. I further suggest that addressing information gaps represents a key-if not the key-to environmental progress.

In Part II, I trace out how pervasive information gaps determine the structure and functioning of the institutions that support pollution control and natural resource management. I argue that the need for gap filling defines the ends as well as the means of environmental law. In particular, I try to explain why corrective justice has disappeared as a central goal in the environmental realm. I also note that the current legal framework, which focuses on internalizing externalities in a least-social-cost fashion, tends to mishandle environmental problems that arise from ignorance or mistake rather than externalities.

In Part III, I explore how improved data collection, analysis, and dissemination are poised to fill critical information gaps and thus change the context of environmental decisionmaking. Problems will become easier to spot, and trends will become more visible. Policymakers will be better positioned to model the flow of harms, predict impacts, and measure effects. A more data-intensive world will facilitate quantitative performance measurement, comparative analysis, and the benchmarking of results. Easier data access and broader dissemination of critical facts and figures will make for a more transparent policy process, engage new actors, and democratize decisionmaking. Alongside the opportunities created by the Information Age, I highlight a set of new challenges-some a function of the changed information context and others that reflect longstanding pathologies that plague environmental decisionmaking today.

In Part IV, I survey our current approaches to environmental protection and analyze how a more information-intensive world could affect our institutional design and regulatory strategies. I suggest that information technologies will improve the functioning of all our pre- 
sent approaches to pollution control and natural resource management-and make inaction appropriate in a shrinking number of circumstances. Most importantly, I argue that the optimal mix of environmental policies and strategies is likely to evolve as more complete information changes the relative costs and benefits of various institutional approaches to solving environmental problems.

Although the gains from a more information-rich world will penetrate the environmental regime on their own over time, Part V explores how this process might be accelerated. I note that not only does our capacity to fill information gaps affect our choice of institutional structures and regulatory tools, but also that our institutional choices simultaneously affect the flow of data and information that is available to support environmental decisionmaking. I thus identify a set of options to restructure the incentives for data production and analysis with a focus on the "least-cost information providers" in order to bring information more effectively into the environmental policy space. ${ }^{11}$

While the coming era of information-based environmental protection holds tremendous opportunities for progress and more refined institutional design, it is important to note that the precise pace and path of policy reform is hard to predict. The revolution in environmental protection that this Article envisions will emerge not in a linear fashion but rather in a more uneven two-steps-forward-onestep-back way. Harnessing the power of information technology will require a nuanced understanding of the relationship between environmental information and institutional design. This Article represents a first step.

\section{I \\ DeFining the Role of INFORMATION IN THE ENVIRONMENTAL REALM}

The importance of good data and reliable information for sound environmental decisionmaking seems obvious: Without basic data, externalities cannot be identified and internalized, ${ }^{12}$ and those who

11 An emphasis on identifying the least-cost information provider can be traced to pathbreaking work in the 1970 s, applying economic analysis to nuisance law. See, e.g., Robert C. Ellickson, Alternatives to Zoning: Covenants, Nuisance Rules, and Fines as Land Use Controls, 40 U. CHI. L. REv. 681, 719-61 (1973); Edward Rabin, Nuisance Law: Rethinking Fundamental Assumptions, 63 VA. L. REv. 1299, 1335-41 (1977); see also Jeff L. Lewin, Compensated Injunctions and the Evolution of Nuisance Law, 71 IOWA L. REv. $775,809-10$ (1986) (highlighting fact-finding costs as critical variable).

12 The "economics of information" and "search costs" have been a critical point of analysis in the economic realm. See Joseph E. Stiglitz, The Contributions of the Economics of Information to Twentieth Century Economics, 115 Q.J. ECON. 1441 (2000) (discussing 
bear the costs of pollution cannot be made whole. ${ }^{13}$ It thus has long been understood that information gaps lead to market failures, ${ }^{14}$ legal system breakdowns, ${ }^{15}$ and regulatory difficulties. ${ }^{16}$

But much of the academic literature on how to improve environmental outcomes has touched on information issues only indirectly or in passing. Significant scholarly work in the environmental field has addressed particular sources of regulatory failure, including publicchoice distortions in policymaking, ${ }^{17}$ federalism and questions con-

information asymmetries and costs and their implications for markets); see also George A. Akerlof, The Market for "Lemons": Qualitative Uncertainty and the Market Mechanism, 84 Q.J. EcoN. 488 (1970) (explaining how asymmetric information prevents market efficiency and leads to undercreation of social goods); Steve Salop, Information and Monopolistic Competition, 66 AM. ECON. REv. 240 (1976) (discussing how information costs may reinforce monopolistic competition); George J. Stigler, The Economics of Information, $69 \mathrm{~J}$. Pol. ECON. 213 (1961) (identifying information and search costs as key determinants of prices and price dispersion); John Joseph Wallis \& Douglass C. North, Measuring the Transaction Sector in the American Economy, 1870-1970, in LONG TERM FACTORS IN American Economic Growth 95 (Stanley L. Engerman \& Robert E. Gallman eds., 1986) (proposing framework for quantifying transaction costs).

13 Making victims whole has been a goal of law in this context for centuries. See RESTATEMENT (SECOND) OF TORTS $§ 901$ (1979) (stating that damages in tort liability are allocated to "give compensation, indemnity or restitution for harms"); see also Aldred's Case, 77 Eng. Rep. 816 (1611) (articulating principle that one should use his own property in such manner as not to injure that of another). This goal, however, is frequently elusive. See Peter H. Schuck, The Limits of Law: Essays on Democratic Governance $438-40(2000)$ (arguing that court system is overwhelmed by need to synthesize multiple sources of information).

14 William J. Baumol \& Wallace E. Oates, The Theory of Environmental PoLICY 18 (1988) (explaining role of information in environmental externalities).

15 For example, nuisance proves to be an awkward way to address environmental problems as harms become more complex, diverse, and diffuse, and as the numbers of harm causers and victims grow. See A. Mitchell Polinsky, Resolving Nuisance Disputes: The Simple Economics of Injunctive and Damage Remedies, 32 Stan. L. Rev. 1075, 1100-09 (1980) (discussing difficulties courts face in resolving nuisance cases when information is incomplete or multiple parties are involved); see also ScHUcK, supra note 13, 438-40 (identifying information overload in court system); Krier \& Schwab, supra note 3, at 479-80 (highlighting failures in tort regime). Indeed, the information challenges inherent in the tort system hastened the rise of state and federal regulatory solutions. See supra note 3.

16 See Davies \& Mazurek, supra note 5, at 269 (concluding that "the fragmented [regulatory] system is seriously broken"); NeIl K. KoMESAR, IMPERfECT Alternatives: Choosing Institutions in Law, Economics, and Public Policy 102-03, 117-21 (1994) (arguing that high information costs deter public participation and enable control by rentseeking minorities); LANDY ET AL., supra note 5, at 6-7 ("The history of environmental policy abounds with examples of the price to be paid for ignoring the [feasibility, effectiveness, and efficiency of proposed remedies]"); ANTHONY I. OGUS, Regulation: LEGAL FORM AND ECONOMIC THEORY 204-10 (1994) (explaining how information gaps imperil effective environmental regulation).

17 See, e.g., Richard L. Revesz, Federalism and Environmental Regulation: A Public Choice Analysis, 115 HaRv. L. Rev. 553 (2001) (rejecting public choice arguments as basis for federalizing environmental law). See generally Jerry L. Mashaw, Greed, Chaos, and Governance: Using Public Choice to Improve Public Law (1997) (examining 


\section{cerning which level of government should undertake environmental} responsibilities, ${ }^{18}$ and risk-perception problems. $^{19}$ Additional emphasis has been placed on regulatory inefficiency and strategies for addressing bureaucratic shortcomings-such as economic incentives, ${ }^{20}$ "regulatory competition," 21 and improved cost-benefit analysis. ${ }^{22}$

public choice interpretations of legislative and administrative agency behavior); Matthew D. McCubbins et al., Administrative Procedures as Instruments of Political Control, 3 J.L. ECON. \& ORG. 243 (1987) (advocating use of administrative procedures as tool for controlling regulatory process).

18 See generally Henry N. Butler \& Jonathan R. Macey, Externalities and the Matching Principle: The Case for Reallocating Environmental Regulatory Authority, 14 YALE L. \& POL'Y REV. 23 (1996) (arguing that jurisdiction for pollution control should correspond to size of area affected by particular pollution source); Richard B. Stewart, Madison's Nightmare, 57 U. CHI. L. REv. 335 (1990) (discussing problems of interest group influence and command-and-control rigidity in federal regulatory approaches); Richard B. Stewart, Pyramids of Sacrifice? Problems of Federalism in Mandating State Implementation of National Environmental Policy, 86 Y ALE L.J. 1196 (1977) (evaluating appropriateness of federal government compelling state action on environmental issues).

19 See generally Stephen Breyer, Breaking the Vicious Circle: Toward Effective Risk Regulation 33-39 (1993); Paul Slovic, The Perception of Risk (Ragnar E. Löfstedt, ed., 2000); John D. Graham \& Jonathan B. Wiener, Confronting Risk Tradeoffs, in Risk Versus Risk: Tradeoffs in Protecting Health and the Environment 1 (John D. Graham \& Jonathan B. Wiener eds., 1995) (explaining how countervailing risks undercut risk reduction strategies); Timur Kuran \& Cass R. Sunstein, Availability Cascades and Risk Regulation, 51 STAN. L. REv. 683, 705-12 (1999) (arguing that heuristic devices and social pressures distort risk perceptions, generating inappropriate regulatory outcomes); Jeffrey J. Rachlinski \& Cynthia R. Farina, Cognitive Psychology and Optimal Government Design, 87 CORNELL L. Rev. 549 (2002) (surveying cognitive sources of regulatory failure); Cass R. Sunstein, Probability Neglect: Emotions, Worst Cases, and the Law, 112 YALE L.J. 61, 61-63 (2002) (explaining human inability to comprehend probability differentials).

20 See generally Bruce A. Ackerman \& Richard B. Stewart, Reforming Environmental Law: The Democratic Case for Market Incentives, 13 Colum. J. EnvTl. L. 171 (1988) (explaining administrative and institutional advantages of market-based systems); Robert W. Hahn \& Robert N. Stavins, Incentive-Based Environmental Regulation: A New Era from an Old Idea?, 18 EcOLOGY L.Q. 1 (1991) (identifying factors that have contributed to and inhibited use of market-based mechanisms); Project 88-Harnessing Market Forces to Protect The Environment: Initiatives for the New President, A Public Policy Study Sponsored by Sen. Timothy E. Wirth and Sen. John Heinz (Robert N. Stavins ed., 1988), available at $\mathrm{http} / / / \mathrm{www}$.heinz.org/files/Project88.PDF.

21 Compare Daniel C. Esty, Revitalizing Environmental Federalism, 95 MICH. L. Rev. 570 (1996) (arguing that centralized programs of environmental regulation will yield better outcomes than decentralized systems of "regulatory competition"), with Richard L. Revesz, Rehabilitating Interstate Competition: Rethinking the "Race-to-the-Bottom" Rationale for Federal Environmental Regulation, 67 N.Y.U. L. REv. 1210 (1992) (arguing that competition among states may yield innovative regulatory policies). See generally REGUlatory Competition and Economic Integration: Comparative Perspectives (Daniel C. Esty \& Damien Geradin eds., 2001).

22 See BREYER, supra note 19, at 59-68 (advocating science-based regulatory body to improve risk/benefit calculations); ECONOMIC ANALYSES AT EPA, supra note 5 (highlighting potential regulatory applications of, and gains to be had from, better cost-benefit analysis); W. Kip Viscusi, Fatal Tradeoffs: Public and Private Responsibilities FOR RISK (1992) (proposing ways for risk analyses to reflect costs and societal tradeoffs); 
While data gaps sometimes are mentioned as an issue, pervasive uncertainties are simply assumed by most scholars to be part of the framework within which environmental law must operate. ${ }^{23}$ This Part, after surveying the existing literature, identifies and categorizes the relevant information gaps. The resulting taxonomy serves as the foundation for later analysis.

\section{A. Information Issues in the Environmental Literature}

Perhaps the most theoretically significant examination of the role of information in environmental law is the work of James Krier in the 1970s. Building on the economic analyses of Demsetz and Coase and the "law and economics" work of Calabresi and others, Krier dissects the information-cost implications of various institutional approaches to environmental protection. ${ }^{24}$ Krier and coauthor W. David Montgomery argue that a regime of private property rights may reduce transaction costs in information, ${ }^{25}$ but they note that a private property system entails administrative costs that may not be justified when the externalities are small. ${ }^{26}$ Describing regulation as the polar opposite of a private property rights regime, Krier and Montgomery observe that, in some cases, government intervention will minimize information burdens and thus the cost of achieving a more efficient resource allocation. Specifically, where the costs of understanding a problem, communicating knowledge about the problem, or policing are high, a regulatory approach may be superior to a regime of private property rights. ${ }^{27}$ In such cases, regulation rather than negotiation

Graham \& Wiener, supra note 19 , at $29-41$ (advocating risk balancing formula to make policy determinations).

23 See, e.g., Percival ET AL., supra note 4, at 343-45 (discussing prevalence of high level of uncertainty in regulation of toxics); Daniel A. Farber, Probabilities Behaving Badly: Complexity Theory and Environmental Uncertainty, 37 U.C. DAvis L. REv, 145, 148-52 (2003) (reviewing uncertainties in environmental law); Bradley C. Karkkainen, Information As Environmental Regulation: TRI and Performance Benchmarking, Precursor to a New Paradigm?, 89 GEO. L.J. 257, 283-86 (2001) (emphasizing that environmental regulation is characterized by uncertainty and data gaps).

24 See James E. Krier \& W. David Montgomery, Resource Allocation, Information Cost and the Form of Government Intervention, 13 NAT. ResourCES J. 89 (1973) (arguing that pricing system of pollution regulation will economize on information costs while achieving greater allocative efficiency than traditional standard-based regulations); see also JAMEs E. Krier, Environmental Law and Policy: Readings, Materials and Notes on Air Pollution and Related Problems 293-468 (1971); James E. Krier \& Edmund Ursin, Pollution and Policy: A Case Essay on California and Federal Experience with Motor Vehicle Air Pollution 1940-1975 (1977) (evaluating institutional approaches to combating motor vehicle air pollution); Krier \& Schwab, supra note 3, at 453-57 (highlighting burden of transaction and "assessment" costs).

25 Krier \& Montgomery, supra note 24 , at $93-94$.

26 Id . at 94-95.

27 Id. at $94-95,96$. 
economizes on the particularized information required for an efficient outcome.

Krier and Montgomery identify two intermediate institutional options that lie between a private property approach and full-scale government regulation: subsidization and pricing. ${ }^{28}$ These approaches tend to lower administrative costs, overcome the inherent inefficiency of uniform standards, and permit emission limitations to vary with the marginal cost of control for each source. ${ }^{29}$ In particular, pricing, which we now call "market-based" regulation, creates incentives that draw out decentralized information from market participants in ways that lower costs and improve efficiency. Krier's work, identifying the incentives for information generation as the crux of the institutional environmental protection design challenge, provides an important starting point for this Article.

A small number of legal scholars recently have begun to look at the fundamental role of information in environmental problemsolving. ${ }^{30}$ In a thoughtful article analyzing the shift in the U.S. economy from manufacturing to services, James Salzman briefly explores the potential impacts of the information revolution on the environment. ${ }^{31}$

Most of the recent "information" scholarship that has emerged in the environmental law arena, however, has had a rather narrow focus. Considerable attention has been paid to the potential for "information regulation." 32 Much of this analysis focuses on the EPA's Toxics

28 Id. at 97 .

29 J.H. Dales, Pollution, Property, and Prices 81-84 (1968) (spelling out economic logic of marginal costs emissions pricing), reprinted in KRIER, supra note 24 , at 294-97.

30 E.g., Gail Charnley \& E. Donald Elliot, Risk Versus Precaution: Environmental Law and Public Health Protection, 32 ENVTL. L. ReP. 10,363 (2002) (discussing primacy of quantitative risk assessment in regulatory decisionmaking and arguing that effective risk policy must change as new information emerges); Dennis D. Hirsch, Globalization, Information Technology, and Environmental Regulation: An Initial Inquiry, 20 VA. ENVTL. L.J. 57 (2001) (predicting that globalization and advances in information technology will improve environmental regulation).

31 Although he finds positive environmental feedback loops among key recent trendsdeindustrialization, information technology gains, economic consolidation, and globalization-Salzman concludes that the decline in manufacturing has been overstated and that the potential for environmental improvements from the "New Economy" still lie in the future. James Salzman, Beyond the Smokestack: Environmental Protection in the Service Economy, 47 UCLA L. REv. 411, 415-18 (1999); see also Bruce Guile \& Jared Cohon, Sorting Out a Service-Based Economy, in Thinking Ecologically: The Next Generation of Environmental Policy 76 (Marian R. Chertow \& Daniel C. Esty eds., 1997) [hereinafter THINKING ECOLOGICALLY] (highlighting need to restructure environmental policy and law to address shift in economy from manufacturing to services).

32 See, e.g., Ogus, supra note 16, at 121-49 (explaining concept and providing examples of information regulation); David W. Case, The Law and Economics of Environmental 
Release Inventory (TRI) Program ${ }^{33}$ and the disclosure of environmental information as a means for changing corporate behaviorthrough "regulation by revelation," 34 public outcry, 35 or betterinformed consumer choice. ${ }^{36}$ Whether aiming to encourage polluters to behave better, to inspire regulators, or to engage consumers, those writing in this vein all seek to improve policy outcomes through revised information flows. A related line of scholarship focuses on the possibility that more information, systematic analysis of data, and better environmental management systems will make corporations more "reflexive" and thus more attentive to the demands of environmental stewardship. ${ }^{37}$

Information as Regulation, 31 ENVTL. L. REP. 10,773, 10,776-81 (2001) (summarizing economic analyses of information regulation); Paul R. Kleindorfer \& Eric W. Orts, Informational Regulation of Environmental Risks, 18 RISK ANALYsis 155 (1998); Cass R. Sunstein, Informational Regulation and Informational Standing: Akins and Beyond, 147 U. PA. L. REV. 613, 626 (1999) (proposing information disclosure as regulatory tool that triggers political rather than market safeguards).

33 See James T. Hamilton, Pollution Is News: Media and Stockmarket Reactions to the Toxics Release Inventory Data, 28 J. ENvTL. Econ. \& MGMT. 98 (1995) (examining connection between TRI data and corporate stock prices); Karkkainen, supra note 23, at 286-360 (evaluating effectiveness of TRI program); Madhu Khanna et al., Toxics Release Information: A Policy Tool for Environmental Protection, 36 J. ENvTL. Econ. \& MGMT. 243 (1998) (examining investor reactions to disclosures through TRI); Shameek Konar \& Mark Cohen, Information as Regulation: The Effect of Community Right to Know Laws on Toxic Emissions, 32 J. ENVTL. ECON. \& MGMT. 109 (1997) (providing further examination of relationship between TRI releases and stock prices); Tom Tietenberg, Disclosure Strategies for Pollution Control, 11 EnvTl. \& Resource Econ. 587 (1998) (evaluating effectiveness of various information disclosure programs). But see Mark A. Cohen, Information as a Policy Instrument in Protecting the Environment: What Have We Learned?, 31 ENVTL. L. REP. 10,425, 10,425-26 (2001) (success of TRI may not justify information regulation more broadly); Jan Mazurek, How Fabulous Fableness? Environmental Challenges of Economic Restructuring in the Semiconductor Industry, 32 GREENER MGMT. INT'L 57 (2000) (arguing that TRI fails to account for environmental effects of globalization in U.S. semiconductor industry).

34 See Ann Florini, The Coming Democracy: New Rules for Running a New WORLD 188-90 (2003) (discussing disclosure and transparency as emerging centerpiece for regulation); Archon Fung et al., The Political Economy of Transparency: What Makes Disclosure Policies Sustainable? 23 (2002), at http://www.innovations.harvard.edu/research/ papers/FGW.pdf.

35 See William F. Pedersen, Regulation and Information Disclosure: Parallel Universes and Beyond, 25 HARv. ENvTL. L. Rev. 151, 160-61 (2001) (arguing that disclosure programs may deliberately provoke public outcry that will result in new regulation).

36 See Stephen Breyer, Analyzing Regulatory Failure: Mismatches, Less Restrictive Alternatives, and Reform, 92 HARV. L. REv. 547, 556 (1979) (noting that competitive markets require well-informed consumers); Peter S. Menell, Structuring a Market-Oriented Federal Eco-Information Policy, 54 MD. L. REv. 1435, 1437-42 (1995) (evaluating ecolabels and other programs aimed at informing consumers); James Salzman, Informing the Green Consumer: The Debate Over the Use and Abuse of Environmental Labels, 1 J. IND. ECOL. 11 (1997) (discussing eco-labels).

37 Eric W. Orts, Reflexive Environmental Law, 89 Nw. U. L. REv. 1227, 1252-67 (1995) (developing theory of reflexive environmental law); Stewart, supra note 4, at 127-51 (dis- 
Others have looked at the role of information in specific regulated communities. Mary Lyndon, for instance, argues that laws addressing chemical exposures should be recrafted to encourage production and dissemination of toxicity information. ${ }^{38}$ Wagner sees similar gains in restructuring the incentives for information generation related to toxic products. ${ }^{39}$ McGarity and Shapiro suggest that public disclosure of test results involving pesticides could enhance environmental safety. 40

Those who seek to reorient environmental protection around property rights and a common law legal strategy for protecting those rights sometimes have examined the role of information. ${ }^{41}$ Bruce Yandle, for instance, talks about the need for technologies and institutions to generate information that can help to make property rights definable, defendable, and divestible. ${ }^{42}$ But again, writing in the property rights vein often has been rather narrow. ${ }^{43}$

Some attention to information questions has emerged in the environmental policy literature, especially under the rubric of "industrial ecology." 44 Closed loop production processes, "dematerialization," and more careful "design for the environment"-central concepts in

cussing information regulation as way to drive more reflexive approach to environmental law).

38 Mary L. Lyndon, Information Economics and Chemical Toxicity: Designing Laws to Produce and Use Data, 87 Mich. L. Rev. 1795, 1797-98 (1989).

39 Wendy E. Wagner, Choosing Ignorance in the Manufacture of Toxic Products, 82 Cornell L. Rev. 773, 833-41 (1997).

40 Thomas O. McGarity \& Sidney A. Shapiro, The Trade Secret Status of Health and Safety Testing Information: Reforming Agency Disclosure Policies, 93 HARV. L. REv. 837, 839-40 (1980).

41 See generally Terry L. Anderson \& Donald R. Leal, Free Market Environmentalism (rev. ed. 2001); Bruce Yandle, Common Sense and Common Law for the Environment: Creating Wealth in Hummingbird Economies (1997).

42 Bruce Yandle, Legal Foundations for Evolving Property Rights Technologies, in THE Technology of Property Rights 1, 1-3 (Terry L. Anderson \& Peter J. Hill eds., 2001).

43 In their zeal to promote environmental protection through property rights, many advocates for "common law" environmentalism do not sufficiently acknowledge the causes of market failures. See, e.g., Terry L. Anderson, Viewing Wildlife Through Coase-Colored Glasses, in Who Owns The Environment? 259 (Peter J. Hill \& Roger E. Meiners eds., 1998) (advancing call for contract-based protection of wildlife with limited focus on risk of market failure); Todd J. Zywicki, Environmental Externalities and Political Externalities: The Political Economy of Environmental Regulation and Reform, 73 TUL. L. REV. 845, 868-73 (1999) (explaining persistence of current environmental regulatory regime by public choice model, and suggesting that new view of political dynamics implies new avenues for reform).

44 See, e.g., Robert J. Klee, Note, Enabling Environmental Sustainability in the United States: The Case for Material Flow Inventory, 23 STAN. ENVTL. L.J. (forthcoming 2004) (arguing that compiling comprehensive information on society's use of materials and energy is key first step towards ultimate environmental sustainability). For an introduction to the industrial ecology literature, see generally T.E. Graedel, On the Concept of Industrial Ecology, 21 AnN. Rev. Energy \& ENV'T. 69 (1996). 
industrial ecology - all rely on information production as a way to help reduce emissions and improve efficiency. ${ }^{45}$ Industrial ecologists also have started to explore the implications of improved data management for achieving efficiency up and down the chain of production, ${ }^{46}$ and have engaged in some broader analysis of the "ecology" of the Information Age economy. ${ }^{47}$

Information gaps have been a major focus of attention in economics-indeed, Joseph Stiglitz recently won the Nobel Prize in economics for his work on information asymmetries. ${ }^{48}$ But, in environmental economics, information problems have often been addressed only in passing. ${ }^{49}$ Chichilnisky asserts, for instance, that environmental knowledge is a privately-produced public good that is

45 See Braden R. Allenby, The Information Revolution and Sustainability: Mutually Reinforcing Dimensions of the Human Future, in Information Systems and THE ENviRONMENT 15, 19 (Deanna J. Richards et al. eds., 2001) (demonstrating "fundamental coevolution of the Information Revolution and sustainability"); Thomas E. Graedel \& Robert J. Klee, Industrial and Anthroposystem Metabolism, in 3 ENCYCLOPEDIA OF Global Environmental Change 73 (T. Munn ed., 2001) (discussing how industrial metabolism studies of flow of materials and energy are important diagnostic tools for environmental improvement).

46 See Daniel C. Esty \& Michael E. Porter, Industrial Ecology and Competitiveness, 2 J. IND. ECOL. 35, 37-40 (1998) (discussing how improved information flows may translate into greater resource productivity); Paul R. Kleindorfer \& Eli M. Snir, Environmental Information in Supply-Chain Design and Coordination, in INFORMATION SySTEMS AND THE ENVIRONMENT, supra note 45, at 115, 127-30 (demonstrating how better information can improve environmental performance through minimization of use of raw materials, transportation optimization, reduced emissions, better logistics, and other means).

47 See, e.g., Lester R. Brown, Eco-Economy: Building an ECONOMy for the EARTH 4 (2001) (arguing that environmentally sustainable economy "requires that the principles of ecology establish the framework for the formulation of economic policy"); Digital Futures: Living iN A Dot-COM World, supra note 7 (examining social and environmental opportunities presented by e-commerce); ECOLOGY OF THE NEw Economy, supra note 7; Jan MazUrek, Making Microchips: Policy, Globalization, ANd EConomic Restructuring in the Semiconductor Industry (1999) (assessing environmental impact of economic changes that have shaped semiconductor industry); Technological Change and the Environment (Arnulf Grübler et al. eds., 2002) (highlighting environmental effects from technological advances).

48 Stiglitz, supra note 12 (discussing how examination of information asymmetries and costs has informed understanding of markets).

49 Kip Viscusi has addressed information as a regulatory issue with some reference to environmental issues. See, e.g., Wesley A. Magat \& W. Kip Viscusi, Informational APPROACHES to REgULATION (1992) (assessing impact of hazard warning regulations); W. Kip Viscusi, Rational RisK Policy (1998) (examining government's role in providing risk information to consumers). Lawyer-economists such as Steven Shavell have, of course, contributed significantly to the Cathedral debate, discussed infra note 55. Others, such as Polinsky, see infra note 57, and, more recently Pfaff and Sanchirico, see infra note 303 , have explored the incentives created by disclosure rules. But little of this work looks at information as a central regulatory failure. 
nonrival in consumption. ${ }^{50}$ But she overlooks the fact that a great deal of environmental data and information is publicly generated.51 Moreover, a good bit of privately generated environmental knowledge is not shared publicly but instead guarded for commercial advantage. This work, moreover, seems to miss the institutional dimension of information production.

Finally, a number of legal scholars have explored information issues in a broader regulatory context. Peter Schuck discusses the information demands of legal systems, markets, and social norms and develops a theory of the "economy of information." 52 In a series of articles, Cass Sunstein explores the connections between information and efficient regulation. ${ }^{53}$ Colin Diver, Richard Posner, and others address the question of the optimal specificity of regulation and legal rules. ${ }^{54}$ This Article seeks to build on these lines of scholarship, honing in on the role of information in the environmental domain.

50 Graciela Chichilnisky, Knowledge and the Environment: Markets with Privately Produced Public Goods, in Environmental Markets: Equity and EfFiciency 242, 242-43 (Graciela Chichilnisky \& Geoffrey Heal eds., 2000).

51 Dozens of reports are put out each year by the U.S. Environmental Protection Agency (EPA), the Department of the Interior, and other government agencies. Environmental knowledge also emanates from public research centers such as EPA laboratories, the National Academy of Sciences, and the National Institutes of Health. Governmentsupported research, such as work funded by the National Science Foundation at academic institutions, produces a vast store of additional data and analysis. Nonprofit think tanks and private research centers also generate significant data, information, and learning with a degree of public funding. It is therefore a significant oversimplification to see environmental knowledge as privately produced. See generally Joseph E. Stiglitz, Knowledge as a Global Public Good, in Global Public Goods: International Cooperation in the 21st CENTURy 308, 311 (Inge Kaul et al. eds., 1999) (arguing that state plays role in producing knowledge through intellectual property regimes).

52 SCHUCK, supra note 13 , at $438-40$.

53 Cass R. Sunstein, Free Markets and Social Justice 327-28 (1997); Kuran \& Sunstein, supra note 19 (cautioning against regulatory decisions rooted in false information); Richard H. Pildes \& Cass R. Sunstein, Reinventing the Regulatory State, 62 U. CHI. L. Rev. 1 (1995) (advocating for increased emphasis on information generation and disclosure in federal regulations); Sunstein, supra note 32 (proposing information disclosure as regulatory tool that triggers political rather than market safeguards); Cass R. Sunstein, Informing America: Risk, Disclosure and the First Amendment, 20 FLA. ST. U. L. REv. 653, 655-61 (1993) [hereinafter Sunstein, Risk] (discussing importance of information in effective risk regulation and stressing government's fundamental role in providing it).

54 Colin S. Diver, The Optimal Precision of Administrative Rules, 93 Y ALE L.J. 65 (1983) (providing model for determining appropriate degree of regulatory precision); Isaac Ehrlich \& Richard A. Posner, An Economic Analysis of Rulemaking, 3 J. LEGAL STUD. 257, 261-77 (1974) (exploring "optimum precision of legal obligation"); see also RICHARD A. Posner, Economic Analysis of Law 367-70 (4th ed. 1992) (arguing that key question is whether benefits of particularization outweigh costs). Compare RICHARD A. EPSTEIN, SimPle Rules FOR A COMPLEX WORLD 30-36 (1995) (arguing for simpler rules to achieve higher overall productivity), with Louis Kaplow, $A$ Model of the Optimal Complexity of Legal Rules, 11 J.L. ECON. \& ORG. 150, 161 (1995) (arguing that complexity arises because precisely tailored rules provide benefits). 


\section{B. A Deeper Theory of Information}

In the Section that follows, I explore the breadth and depth of the information failures that plague environmental protection efforts. Mapping this terrain is a critical first step toward understanding the potential for environmental gains from Information Age technologies and the value of designing institutions to promote information generation.

The debate over whether property rules or liability rules are the best way to protect entitlements (and especially Calabresi and Melamed's seminal Cathedral analysis) illuminates some of the ways information needs come into play in the context of environmental problems. But this line of analysis has also cast a long shadow across the academic literature and narrowed the thinking on where the critical information gaps lie. In seeking to reframe the scholarly debate, I highlight an array of foundational data and information issues that are essential to good environmental decisionmaking-but which lie "beneath" the Cathedral discussion.

\section{The Shadow of the Property Versus Liability Rules Debate}

Calabresi and Melamed powerfully demonstrated that the choice of legal rules to protect entitlements affects efficiency. The Cathedral article and its progeny have sharpened the focus of a generation of legal scholars on the ways in which property and liability rules can (1) be utilized, refined, and combined to generate information on the value of harms (and the burdens of abatement); (2) limit strategic bargaining; and (3) reduce the inefficiency created by holdouts. ${ }^{55}$

55 See Calabresi \& Melamed, supra note 2; see also Ian Ayres \& Eric Talley, Distinguishing Between Consensual and Nonconsensual Advantages of Liability Rules, 105 Y ALE L.J. 235, 252 (1995) (arguing that "liability rules may induce more efficient postbargaining outcomes even when no nonconsensual advantage exists"); Ian Ayres \& Eric Talley, Solomonic Bargaining: Dividing a Legal Entitlement to Facilitate Coasean Trade, 104 Y ALE L.J. 1027, 1083-90 (1995) (spelling out bargaining obstacles); Ian Ayres \& J.M. Balkin, Legal Entitlements as Auctions: Property Rules, Liability Rules, and Beyond, 106 Y ALE L.J. 703, 706-07 (1997) (distinguishing between higher-order liability rules and first-order liability principles); Richard R.W. Brooks, The Relative Burden of Determining Property Rules \& Liability Rules: Broken Elevators in the Cathedral, 97 Nw. U. L. Rev. 267 (2002) (discussing valuation burdens courts face); Louis Kaplow \& Steven Shavell, Property Rules Versus Liability Rules: An Economic Analysis, 109 Harv. L. Rev. 713 (1996) (explaining why liability rules may be superior to property rules); Carol M. Rose, The Shadow of The Cathedral, 106 YALE L.J. 2175, 2193-94 (1997) (suggesting that liability rules require courts to do more than determine average damages from pollution); Steven Shavell, Liability for Harm Versus Regulation of Safety, 13 J. LEGAL STUD. 357, 359 (1984) (arguing for liability rules rather than regulation where private parties are in better position to assess risks than government). 
The framework of legal rules does, undoubtedly, shape the incentives for information production. But as Carol Rose argues, the conclusions drawn from various contributions to the Cathedral debate are a function of the examples put forward.56 The structure of the hypotheticals chosen defines the analysis, assumes away certain issues, and focuses the reader on others..$^{57}$ Rose notes that the "shadow examples" affect not only the choice of rules, but also the content of the entitlements. ${ }^{58}$

I contend that the shadow of the Cathedral is even more overwhelming, distracting the scholarly community from the broader set of information issues at play in the environmental domain. In fact, while Calabresi and Melamed use environmental nuisance to illuminate their argument, they really have in mind the law of accidents. They ignore the underlying issue of whether there was an accident in the first place. ${ }^{59}$ More importantly, the Cathedral examples-and a focus on nuisance cases more generally-stylize the environmental problem in a way that oversimplifies the information issues, highlighting a few concerns (e.g., the challenge of assessing damages and preventing holdouts) to the exclusion of others. In the pollution context, the existence, contours, sources, movement, and impact of the harm in question cannot be taken for granted.

\section{Beneath the Cathedral}

People affected by pollution often do not know what potential environmental injuries they face, where particular harms are coming from, how much those harms affect them, what value to place on the injuries or effects they suffer, nor whether they have a right to be free of the harm. Under these circumstances, a Calabresian bargaining breakdown is the least of their problems. While some of these information failures arise from the incentives created by legal rules, other

56 Rose, supra note 55, at 2177-97 (discussing "shadow examples"). Rose further notes that contract law is the shadow example in the work of Ayres and Talley and that Kaplow and Shavell again work from the shadow of the law of accidents. Id. at 2176 .

57 Polinsky, for instance, assumes the government has "full information about the externality problem." A. Mitchell Polinsky, Controlling Externalities and Protecting Entitlements: Property Right, Liability Rule, and Tax-Subsidy Approaches, 8 J. LeGAL STud. 1, 2 (1979).

58 Rose, supra note 55 , at 2179.

59 Calabresi's work on accidents in the late 1960s furthermore came against the backdrop of a major policy debate about "no-fault" auto insurance, designed to overcome bargaining breakdowns over how to tally damages in the context of car accidents. See, e.g., Robert E. Keeton \& Jeffrey O'Connell, Basic Protection for the Traffic Victim: A Blueprint for Reforming Automobile Insurance 180-81 (1965). Calabresi's work-and thus his examples-also predate the rise of a statutory approach to pollution control. 
gaps are more a function of science or values, and thus require a quite different line of attack to fix. ${ }^{60}$

Modern day pollution control problems are rarely of the simple " $A$ causes harm to $B$ " type that the property-versus-liability-rules debate explores. Under an even slightly more complex model-with multiple polluters (or harm causers) $P, P^{\prime}$, and $P^{\prime \prime}$; multiple "pollutees" (or victims) $V, V^{\prime}$, and $V^{\prime \prime}$; and multiple pollutants (or emissions) $E, E^{\prime}$, and $E^{\prime \prime}$ causing harm $X$-a much broader array of information failures can be identified.

\section{(a) Problem Identification}

In the environmental domain there is often a great deal of uncertainty about whether a problem even exists. In Calabresi's world, $V$ knows he has been harmed by $P$. In the case of an accident, $V$ knows that $P$ 's car has hit him causing harm $X$. Calabresi and other Cathedral commentators also use nuisance examples in which $V$ is assumed to be aware of $P$ 's harm to him. In the broader pollution context, however, $V$ may not see the emissions from $P$ 's factory smokestack. In fact, $V$ may not even see $P$ 's factory, which may be many miles away. Even if $V$ sees the smoke in the air or emissions going into the water, he may not be able to tell if this pollution is harmful. To establish the existence of a harm, several basic questions must be answered:

- Is $P$ emitting $E$ ?

- Does $E$ cause harm?

To complicate this set of "existence" issues, many environmental harms are not identified until many years after they have been generated. Chlorofluorocarbons (CFCs) were considered miracle chemicals in the 1950s with uses that ranged from cleaning semiconductors to refrigeration. Only in the 1970 s and 1980 s was it recognized that CFCs were depleting the ozone layer. ${ }^{61}$ The inability to see many problems arises from the fact that modern-day pollutants are often, quite literally, invisible. Other harms are spatially or temporally diffused. Problems may not emerge until an ecosystem's assimilative capacity is overwhelmed or other critical thresholds are crossed. The

60 Some of the problems may also be "beyond science" and related to disputes over values. On the role of values and culture more generally, see Dan M. Kahan \& Donald Braman, More Statistics, Less Persuasion: A Cultural Theory of Gun-Risk Perceptions, 151 U. PA. L. Rev. 1291 (2003) (arguing that what people accept as fact depends on personal values and culture). See also Wendy E. Wagner, The Science Charade in Toxic Risk Regulation, 95 Colum. L. Rev. 1613, 1619-22 (1995) (separating problems science can address from "trans-science" issues that require political judgment).

61 See Richard Elliot Benedick, Ozone Diplomacy: New Directions in SafeGUARDING THE PLANET 9-22 (1998) (summarizing development of scientific knowledge regarding CFCs and depletion of ozone layer). 
invisible buildup of carbon dioxide and other greenhouse gases in the atmosphere-potentially causing climate change over a period of decades or centuries-is the paradigmatic example of the hidden harm spilling across space and time. To the harm identification taxonomy, we must therefore add:

- Can $V$ (or $V^{\prime}$ or $\left.V^{\prime \prime}\right)$ perceive $E$ ?

\section{(b) Causal Specification}

Even if the existence of a potential harm is clear, important questions may remain about its actual impact and thus its potential for damage to people or the natural environment. In the ecological sciences, these issues are studied as matters of the "fate and transport" of pollutants. ${ }^{62}$ In the law, these questions are analyzed as a matter of causation. We need information to establish a link from particular emissions to specific receptors or pollutees:

- Does $P$ 's $E$ affect $V$ ?

In reality, the information issues and uncertainties surrounding causal linkages are even more complex. Notably, $V$ may be affected by emissions from sources other than $P$. Are the particulates $V$ is breathing from the power plant next door $(P)$ ? The factory across town $\left(P^{\prime}\right)$ ? The cars miles upwind $\left(P^{\prime \prime}\right)$ ? Moreover, $P$ 's emissions and those of $P^{\prime}$ and $P^{\prime \prime}$ may well affect not only $V$, but also $V^{\prime}$ and $V^{\prime \prime}$.

It may be, furthermore, that we cannot trace a problem back to its source until multiple victims with similar harms emerge. This makes information exchange across victims and the aggregation of claims important. We therefore have several additional issues to address:

- Do the emissions from $P^{\prime}$ and $P^{\prime \prime}$ affect $V$ ?

- Does $P$ 's $E$ affect $V^{\prime}$ and $V^{\prime \prime}$ ?

- Do $V, V^{\prime}$ and $V^{\prime \prime}$ recognize themselves to be victims of a problemin-common?

\section{(c) Impact Evaluation: Epidemiological and Ecological Effects}

Even when we can trace emissions of $E$ from $P$ to $V$, uncertainties about how the pollution affects the pollutee may persist. In the

62 See, e.g., Jerald L. Schnoor, Environmental Modeling, Fate and Transport of Pollutants in Water, Air and SoIl (1996) (proposing mathematical model of environmental pollutants to gain better understanding of fate and transport of chemicals); Richard J. Watts, Hazardous Wastes: Sources, Pathways, Receptors 405-37 (1998) (employing mathematical models to describe transportation of contaminants). 
policy domain these issues loom large. Does smog hurt people?63 Do radionuclides in drinking water lead to cancer? ${ }^{64}$ Mere physical contact does not necessarily create a need for redress or intervention. A fundamental starting point for environmental policymaking is that only actual damage or the real risk of injury requires action. Information about the epidemiological and ecological impacts of $E$ must therefore be developed, analyzed, and disseminated. To our catalogue of information needs, we must add:

- Does $E$ harm $V$ ?

- How does $E$ harm $V$ ?

- What dose of $E$ affects $V$ ?

The issue of epidemiological and ecological effects may be further complicated by a number of factors. First, the impacts on $V$ may not occur immediately. As noted above, threshold effects may emerge only after a particular level of exposure or intensity of impact has been realized. A single car in Los Angeles is not a problem, but five million vehicles overwhelm the assimilative capacity of the airshed. In other circumstances, harms accrue over time and only become visible after a certain degree of accumulation.

Second, $V$ 's injuries might be a result of exposure to other pollutants beyond $E$. Is respiratory distress a function of smog? Or rather particulates? Or airborne toxics? This multidimensionality means we must ask:

- Do $V$ 's symptoms come from exposure to $E^{\prime}$ or $E^{\prime \prime}$ as well as to $E$ ?

Third, a further set of information needs emerges at the intersection of harms and causal uncertainties. Particularly vulnerable subgroups of the population-children, older people, or those with compromised immune systems, for example, may all need to be analyzed separately. Moreover, some injuries may be a function of the interaction of one pollutant with another or with other risk factors. Exposure to radionuclides is, for example, much riskier for smokers than nonsmokers. The potential for interactive effects means we must inquire:

- Do $V$ 's symptoms come from the interaction of $E$ with $E^{\prime}$ and $E^{\prime \prime}$ ?

63 See U.S. Envtl. Prot. Agency, Smog-Who Does It Hurt?: What You Need To Know ABout Ozone AND Your HeAlth 3-4 (1999), available at http://www.epa.gov/ airnow/health/smog.pdf.

64 See Nat'l Ground Water Ass'n, Radionuclides: What You Need to Know (2000), available at http://www.ngwa.org/pdf/Radionuclides.pdf (highlighting risks and uncertainties posed by these naturally occurring radioactive contaminants). 
- Are there other factors that aggravate or mitigate $E$ 's impact on $V ?^{65}$

\section{(d) Harm Valuation}

Even if we are able to ascertain the precise physical effects of an identified source of pollution on a pollutee, we face the additional problem of calculating the dollar value of the injuries inflicted. It is at this point that the Cathedral literature picks up. Consistent and appropriate valuation of harms is critical-and subject to real uncertainty. ${ }^{66}$ The valuation calculus raises a number of questions:

- Who should undertake the valuation?

- Is technical expertise required?

- Whose values and valuations should be used? Those of the pollutee? Of society?

- Should we fully compensate victims who are unusually susceptible to harm (e.g., those with weak respiratory or immune systems)?

- Should we fully compensate those whose own behavior (e.g., smoking) creates the risk of injury or worsens the damage?

- How do we discipline exaggeration or other strategic behavior?

The multiperson, multielement model again reveals additional complexities that add to our information needs and burdens. Specifically, if $V$ is affected by $E$ from $P^{\prime}$ and $P^{\prime \prime}$ as well as $P$, how do we determine for what share or for which units of harm $P$ is responsible? This issue is particularly important in circumstances in which the marginal cost of the harm is not steady, but rising or falling. ${ }^{67}$ The damage assessment questions highlighted by the Cathedral debate are thus significant but cannot be addressed without reference to the broader set of underlying information needs that arise in any environmental decisionmaking context.

65 Age, weight, sex, and other factors such as demographic groups with unusual dietary patterns (e.g., Native Americans who eat a great deal more fish than the rest of the population) may all be relevant variables to examine. See generally JoHn WARgo, OUR CHILdren's Toxic Legacy: How Science and Law Fail to Protect Us from Pesticides (1996) (spelling out how and why some subgroups of population may be more sensitive to certain harms).

66 Polinsky observes that difficulties in calculating damages could be more important than strategic behavior as a source of breakdown in the Calabresi-Melamed model. Polinsky, supra note 15, at 1110-11. Krier and Schwab similarly note that judicial efforts to place a value on harms under liability rules often entail substantial "assessment costs." Krier \& Schwab, supra note 3 , at 453.

67 Rose, supra note 55, at 2195-96 (arguing that average cost is not meaningful with respect to allocating costs of pollution to specific actors, and therefore, polluters will not fully internalize costs of their activities). 


\section{(e) Rights Delineation}

Coasean analysis focuses on what happens after an entitlement has been allocated. The Cathedral debate similarly presumes that there has been an allocation of entitlements prior to deciding whether property or liability rules should be deployed. But in the environmental realm, the delineation of property rights is often a contentious issue, ${ }^{68}$ requiring us to ask:

- Have the relevant property rights been established?

- Are the parties aware of who holds the rights?

- Are the boundaries clear?

Where the rights have been allocated, the inquiry turns to a second set of questions:

- Has there been an encroachment on these rights?

- Can the rightsholder tell that an encroachment has occurred?

- Are the rights easily vindicated?

While Calabresi implicitly (and other contributors to the Cathedral literature more explicitly ${ }^{69}$ ) assumes that the ownership, scope, and boundaries of the relevant property rights are clear, in the real world of environmental decisionmaking they often are not. Considerable effort often goes into ascertaining who holds the relevant rights and whether an externality exists that interferes with those rights. ${ }^{70}$ What constitutes an externality is also a function of values and community norms, which makes the scope of rights fluid and subject to further uncertainties. ${ }^{71}$

68 One dimension of this issue centers on the fairness of the initial allocation of rights. This Article elides such distributive justice issues. As others have noted, without diminishing the seriousness of equity concerns, other more direct policy approaches (e.g., progressive taxation) likely are better to achieve any desired distributive outcome. See, e.g., Kaplow \& Shavell, supra note 55, at 744.

69 See, e.g., Polinsky, supra note 15 , at 1086-88.

70 See Polinsky, supra note 15, at 1100; Paul R. Portney, EPA and the Evolution of Federal Regulation, in Public Policies for Environmental Protection 7, 11-12 (Paul R. Portney et al. eds., 1990) (arguing that nonregulatory approaches are insufficient due to difficulties in defining rights, prohibitive transaction costs, and market imperfections); Carolyn Woj, Property Rights Disputes: Current Fallacies and a New Approach, $14 \mathrm{~J}$. LEGAL STUD. 411, 412 (1985) (arguing that current economic approach overlooks importance of relative value of entitlement as factor in determining value-maximizing exchange).

71 See Robert C. Ellickson, Alternatives to Zoning: Covenants, Nuisance Rules, and Fines as Land Use Controls, 40 U. CHI. L. Rev. 681, 728-29 (1973) (noting that evaluative terms such as "beneficial" and "harmful" often are made with reference to communitydetermined standards of conduct); Robert C. Ellickson, Suburban Growth Controls: An Economic and Legal Analysis, 86 YALE L.J. 385, 429, 475-89 (1977) (noting uncertainty and inconsistency resulting from fact that legality of municipality's exactions and special assessments levied on new developers will turn in part on community's own past taxation and funding practices). 


\section{(f) Policy Intervention}

Once an environmental harm has been identified and deemed worthy of attention, two other sets of questions emerge, centered on: (1) abatement options and costs, and (2) who should take action. In many circumstances, an array of pollution control alternatives needs to be considered: restructured processes, redesigned products, pollution prevention options, "end of pipe" treatment, and so on. Information on these choices and on the costs and benefits of the various alternative actions is critical. Optimizing incentives for creativity and cost minimization in both information generation and intervention is similarly important. ${ }^{72}$

Finally, we need to figure out who should formulate and implement policy. Determining whether $P$ or $V$ is better positioned to reduce the harm provides a useful starting point, but not an endpoint, for this effort. Identifying the least-cost information provider is also important. Given the scientific and technical complexity of many modern-day environmental problems, neither $P$ nor $V$ really may be in a position even to understand the options for abatement of $E$. These added dimensions of uncertainty create new information burdens:

- How do we best reduce the effects of $E$ ?

- What are our policy choices?

- What can be done to motivate innovation in information production and pollution control?

- Who is best positioned to act to reduce $E$ ?

- How do we minimize overall system costs?

\section{(g) Implementation}

Once an optimal abatement strategy has been identified, somebody must act to implement the chosen intervention. In general, these "action" costs will be borne by a private party. But in the regulatory model, a government agency may share action responsibilities. Thus, an additional set of issues arises around how to minimize the costs of administering the intervention strategy:

- Is the selected intervention implemented effectively and efficiently?

- How can administrative costs be minimized?

72 Cf. Michael E. Porter, America's Green Strategy, ScI. AM., Apr. 1991, at 168 (arguing that performance standards rather than technology mandates are key to innovation). 


\section{(h) Monitoring and Enforcement}

Even after responsibility for reducing a pollution harm has been assigned, there remain important questions about whether the responsible party carries out the designated tasks. Courts must ascertain whether their orders are obeyed-and intervene where parties do not comply. Likewise, environmental agencies expend a great deal of time and energy tracking the compliance of polluters. These monitoring and enforcement issues mean that we must add to our list of potential areas for information failure questions such as:

- Did those assigned to reduce harm $X$ do what they were supposed to do?

- How do we best track compliance with our program of $E$ control?

\section{(i) Updating and Refinement}

Given the dynamic nature of environmental problems and the fast pace at which knowledge evolves in the ecological sciences, each element of the foregoing analysis must be constantly reexamined and refined. Changes in circumstances-increased population density, greater scarcity of resources, shifts in the underlying scientific knowledge base, or technological breakthroughs-often will change the answers to questions somewhere along the information track that has just been laid out. To the taxonomy of potential information failures, we must therefore add the following set of issues:

- Is the current approach to $X$ effective?

- Has anyone come up with a better way to deal with harm $X$ ?

- Has new information, knowledge, or technology emerged that might change our assumptions about:

o the existence of $X$ ?

o the fate and transport of $E$ causing $X$ ?

o epidemiological or ecological effects of $E$ ?

o the valuation to be placed on $X$ ?

o who holds the relevant property rights?

o intervention options for dealing with $X$ ?

o how best to monitor compliance with $E$ abatement efforts?

Table 1 summarizes the above taxonomy of pollution control "information needs." 


\section{Table 1: Taxonomy of Environmental Decisionmaking INFORMATION NEEDS}

\begin{tabular}{|c|c|}
\hline Problem Identification: & $\begin{array}{l}\text { - Is } P \text { emitting } E \text { ? } \\
\text { - Does } E \text { cause harm? } \\
\text { - Can } V \text { (or } V^{\prime} \text { or } V^{\prime \prime} \text { ) perceive } E \text { ? }\end{array}$ \\
\hline Causal Specification: & $\begin{array}{l}\text { - Does } P \text { 's } E \text { affect } V \text { ? } \\
\text { Do the emissions from } P^{\prime} \text { and } P^{\prime \prime} \text { affect } V \text { ? } \\
\text { - Does } P \text { 's } E \text { affect } V^{\prime} \text { and } V^{\prime \prime} \text { ? } \\
\text { Do } V, V^{\prime} \text {, and } V^{\prime \prime} \text { recognize themselves to be victims of a problem-in- } \\
\text { common? }\end{array}$ \\
\hline Impact Evaluation: & $\begin{array}{l}\text { - Does } E \text { harm } V \text { ? } \\
\text { - How does } E \text { harm } V \text { ? } \\
\text { - What dose of } E \text { affects } V \text { ? }\end{array}$ \\
\hline $\begin{array}{l}\text { Epidemiological and } \\
\text { Ecological Effects: }\end{array}$ & $\begin{array}{l}\text { Do } V \text { 's symptoms come from exposure to } E^{\prime} \text { or } E^{\prime \prime} \text { as well as } E \text { ? } \\
\text { Do } V \text { 's symptoms come from the interaction of } E \text { with } E^{\prime} \text { and } E^{\prime \prime} \text { ? } \\
\text { - Are there other factors that aggravate or mitigate } E^{\prime} \text { s impact on } V \text { ? }\end{array}$ \\
\hline Harm Valuations: & $\begin{array}{l}\text { Who should undertake the valuation? } \\
\text { - Is technical expertise required? } \\
\text { - Whose values and valuations should be used? Those of the pollutee? } \\
\text { Of society? } \\
\text { - Should we fully compensate victims who are unusually susceptible to } \\
\text { harm (e.g., those with weak respiratory or immune systems)? } \\
\text { - Should we fully compensate those whose own behavior (e.g., smoking) } \\
\text { creates the risk of injury or worsens the damage? } \\
\text { How do we discipline exaggeration or other strategic behavior? }\end{array}$ \\
\hline Rights Delineation: & $\begin{array}{l}\text { - Have the relevant property rights been established? } \\
\text { Are the parties aware of who holds the rights? } \\
\text { - Are the boundaries clear? } \\
\text { - Has there been an encroachment on these rights? } \\
\text { - Are the rightsholder tell that an encroachment has occurred? } \\
\text { - rights easily vindicated? }\end{array}$ \\
\hline Policy Intervention: & $\begin{array}{l}\text { - How do we best reduce the effects of } E \text { ? } \\
\text { - What are our policy choices? } \\
\text { - What can be done to motivate innovation in information production } \\
\text { - Who is best positioned to act to reduce } E \text { ? } \\
\text { - How do we minimize overall system costs? }\end{array}$ \\
\hline Implementation: & $\begin{array}{l}\text { - Is the selected intervention implemented effectively and efficiently? } \\
\text { - How can administrative costs be minimized? }\end{array}$ \\
\hline $\begin{array}{l}\text { Monitoring and } \\
\text { Enforcement: }\end{array}$ & $\begin{array}{l}\text { - Did those assigned to reduce harm } X \text { do what they were supposed to } \\
\text { do? } \\
\text { - How do we best track compliance with our program of } E \text { control? }\end{array}$ \\
\hline $\begin{array}{l}\text { Updating and } \\
\text { Refinement: }\end{array}$ & $\begin{array}{l}\text { - Is the current approach to } X \text { effective? } \\
\text { Has anyone come up with a better way to deal with the harm? } \\
\text { Has new information, knowledge, or technology emerged that might } \\
\text { change our assumptions about: } \\
\text { o the existence of } X \text { ? } \\
\text { o the fate and transport of } E \text { causing } X \text { ? } \\
\text { o epidemiological or ecological effects of } E \text { ? } \\
\text { o the valuation to be placed on } X \text { ? } \\
\text { o who holds the relevant property rights? } \\
\text { o intervention options for dealing with } X \text { ? } \\
\text { o how best to monitor compliance with } E \text { abatement efforts? }\end{array}$ \\
\hline \multicolumn{2}{|c|}{$\begin{array}{l}\text { Where: } \\
\text { Harm }=X \\
\text { Polluters }=P, P^{\prime} \text {, and } P^{\prime \prime} \\
\text { Pollutees }=V, V^{\prime}, \text { and } V^{\prime \prime} \\
\text { Pollutants }=E, E^{\prime}, \text { and } E^{\prime \prime}\end{array}$} \\
\hline
\end{tabular}


The spectrum of potential information failures threatening to disrupt efficient cost internalization is broader than the existing environmental law literature in general, or the Cathedral debate in particular, might lead one to believe. The range of issues may seem daunting. It certainly argues for much more scholarly attention (and policy focus) on categorizing and addressing various information gaps. The multitude of information gaps that are often present in environmental decisionmaking argues for having an array of institutional mechanisms for producing information and for more emphasis on improving the information underpinnings for decisionmaking across the spectrum of environmental harms and responses.

\section{II \\ INFORMATION GAP FILLING}

Information gaps plague environmental decisionmaking from the household level ${ }^{73}$ to the global scale. ${ }^{74}$ The U.S. Environmental Protection Agency (EPA) repeatedly has acknowledged significant shortcomings in the core data sets on which regulatory decisions depend. ${ }^{75}$ The White House Council on Environmental Quality similarly has struggled with the issue of how to fill information gaps in the regulatory realm. ${ }^{76}$ Although scholars have tended to accept uncertainties as a defining feature of the environmental sphere, ${ }^{77}$ observers of the policymaking process have stressed that information problems

73 See Magat \& Viscusi, supra note 49, at 47-65 (highlighting risk detection problems facing consumers); Christine Jolls et al., A Behavioral Approach to Law and Economics, in Behavioral Law and Economics 13, 42-45, 47-48 (Cass R. Sunstein ed., 2000) (noting consumer difficulties in getting and processing risk information).

74 See Intergovernmental Panel on Climate Change, Climate Change 2001: Impacts, Adaptation, AND VUlnerability - Summary FOr Policymakers 14-17 (James J. McCarthy et al. eds., 2001) (identifying high priority areas for narrowing gaps between current knowledge and policymaking needs); Daniel Bodansky, The United Nations Framework Convention on Climate Change: $A$ Commentary, 18 YALE J. INT'L L. $451,454-57,475-76$ (1993) (giving overview of information issues related to global warming).

75 See, e.g., Office of Water, Envtl. Prot. Agency, National Water Quality INVENTORY: 1996 RePORT TO CONGREss 2, 29 (revealing serious water data limitations), available at http://www.epa.gov/305b/96report/index.html; SCIENCE AdvisORY BD., ENVTL. Prot. Agency, Reducing Risk: Setting Priorities and Strategies For Environmental Protection 6-8, 10, 15, 18 (1990) [hereinafter Science Advisory Bd, REDUCING RISK] (identifying numerous data gaps).

76 See Farber, supra note 23, at 164-66 (discussing Council on Environmental Quality's efforts to deal with scientific uncertainty).

77 E.g., Percival Et Al., supra note 4, at 343-405; Karkkainen, supra note 23, at 283-86 ("The world of environmental regulation is characterized by pervasive uncertainty, an overall scarcity of high-quality information, [and] unevenness in its availability and reliability ....); Calabresi, supra note 1, at 1218-19 (noting that information gaps are pervasive and thus "a given degree of friction is a reality of life"). 
represent a fundamental issue holding society back from better results in pollution control and natural resource management. ${ }^{78}$ But the context of environmental protection is changing. The emergence of new information management and communications technologies promise to make data collection, analysis, and dissemination much cheaper, faster, and easier. ${ }^{79}$ This Part argues that institutional design plays a key role in filling information gaps and that, in a like manner, the presence or absence of information gaps significantly influences our choices of both the means and ends of environmental policy.

\section{A. Gap Filling and Institutional Design}

The pioneering work on transaction costs in the context of information and institutional design was done in the late 1970s by Oliver Williamson. Working within the framework of corporate organization and expressly putting aside the Coasean fiction of frictionless transactions, ${ }^{80}$ Williamson observed that most contracts are to some degree incomplete-some issues remain unaddressed or some information remains unspecified. ${ }^{81}$ "Gap filling" to overcome limited information becomes essential to complete the transaction. How voids are filled and whether the institutions used to generate the needed information minimize transaction costs are thus central determinants of economic efficiency. This work has significant implications in the environmental realm: The strategies selected to overcome uncertainties emerge as critical determinants of regulatory efficiency. When crucial informa-

78 E.g., Breyer, supra note 19, at 42-50; Gen. AcCounting Office, GAO-01-257, Major Management Challenges and Program Risks: Environmental Protection Agency 13-21 (Jan. 2001); Gen. Accounting Office, GAO-01-97T, Environ. mental Information: EPA NeEds Better Information to Manage Risks and Measure Results (Oct. 3, 2000); Karl Hausker, Reinventing Environmental Regulation: The Only Path to a Sustainable Future, 29 EnvTL. L. ReP. 10,148, 10,152-53 (1999).

79 Even if the legal issues posed are not entirely new, technological innovation can change the policy framework in important ways. See Jack M. Balkin, Digital Speech and Democratic Culture, 79 N.Y.U. L. REv. (forthcoming 2004) (citing Joseph H. Sommer, Against Cyberlaw, 15 Berkeley TeCH. L.J. 1145, 1148 (2000) ("[F]ew of the legal issues posed by the new information are novel.")).

80 Coase himself stressed the importance of tapping into unexploited information resources and acknowledged the distance between the real world and the theoretical Coasean world. See Ronald H. Coase, The Institutional Structure of Production, 82 AMER. ECON. Rev. 713, 713-19 (1992); see also Ellickson, supra note 1, at 611-12 (pointing out that Coase did not believe that we lived in "Coasean world").

81 Oliver E. Williamson, Markets and Hierarchies: Analysis and Antitrust Implications 141-43, 253-54 (1975) [hereinafter Williamson, MaRkets and HieraRCHIEs]; Oliver E. Williamson, Transaction Cost Economics, in 1 HandBoOK OF INDUSTRIAL ORGANIZATION 135-78 (Richard Schmalensee \& Robert E. Willy eds., 1989); Oliver E. Williamson, Transaction Cost Economics: The Governance of Contractual Relations, 22 J.L. \& ECON. 233, 237 (1979). 
tion gaps go unfilled or are filled in haphazard ways, regulatory efficacy suffers and costs go up.

Following Williamson's work on firms, an array of institutional options for environmental policymaking exist-ranging from a pure "market" (i.e., negotiated exchange of property rights) to a pure "hierarchy" (i.e., command-and-control regulation). ${ }^{82}$ Various intermediate options also can be specified. If the property rights over environmental resources are defined clearly and the transaction costs associated with their purchase and sale are negligible, private party "Coasean" bargaining can reallocate entitlements so as to generate an economically efficient outcome that internalizes externalities. ${ }^{83}$ As we shift, however, from frictionless two-person models to a multiperson reality, information gaps like those identified in Table 1 often become too numerrus and complicated for the parties to bridge on their own. ${ }^{84}$

The relevant question becomes: Which institutional structure will deliver the most efficient information gap filling and environmental harm reduction? This inquiry-and the institutional design issue more broadly-requires a focus on minimizing the sum of "action" costs (the expense of pollution control), "inaction" costs (the burdens of unabated pollution or failure costs), and "transaction" costs (including, most notably, the administrative costs of gap filling across the full array of activities outlined in Table 1). The least-social-cost calculus is spelled out in Table 2 below. ${ }^{85}$

Under a least-social-cost metric, high transaction costs $(T)$-particularly information gap filling costs-can overwhelm the benefits of pollution control (reduced $I$ ). In some circumstances, the costs of intervention to address environmental harms - both action costs $(A)$

82 Because Williamson's analysis centers on corporate organization, his transactioncost-based categorization of institutional structures requires some translation to make sense in the environmental realm. The relevant "transaction" is not that of a firm but the effort to protect (or exchange) environmental property rights. But Williamson's analysis highlights the central thrust of this Article: An inquiry into what institutional structure best fills information gaps, minimizes transaction costs, and provides a least social cost approach to environmental protection. See Williamson, Markets and Hierarchies, supra note 81 , at $136-253$.

83 See Coase, supra note 1 , at 1-8.

84 See Williamson, Markets and Hierarchies, supra note 81, at 136-253; see also Calabresi, supra note 1 , at 1234 \& n.70 (identifying and categorizing barriers to full efficiency).

85 This taxonomy of costs builds on Carol M. Rose, Rethinking Environmental Controls: Management Strategies for Common Resources, 1991 DukE L.J. 1, 12-14. 
Table 2: Least Social Cost Environmental Protection

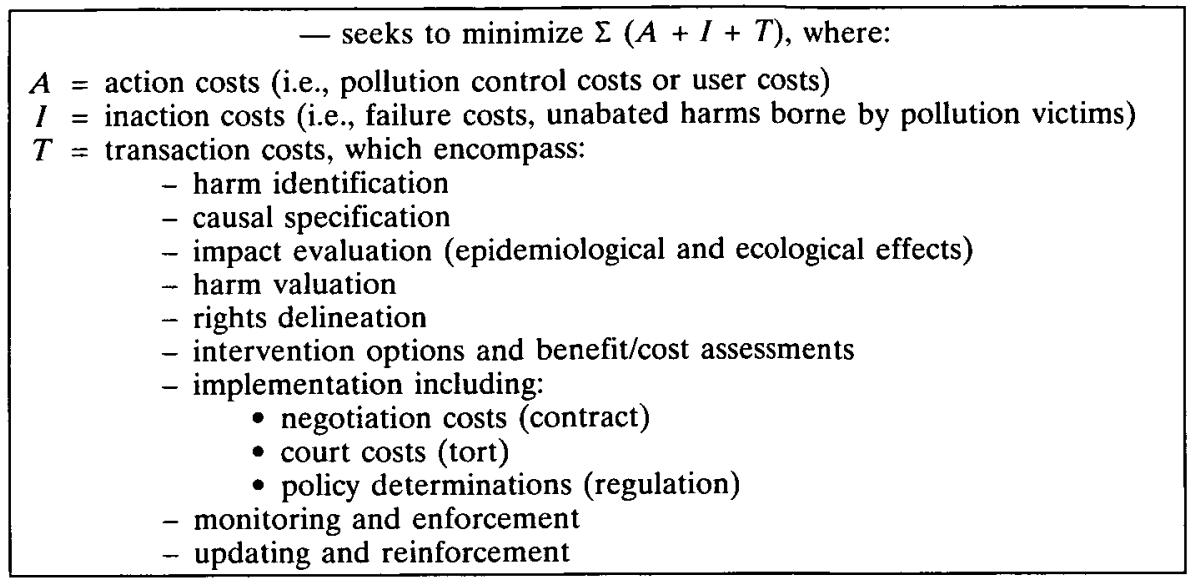

and transaction costs $(T)$-are too high relative to the expected gains (reduced $I$ ) to justify taking any action. ${ }^{86}$

If the gaps to be filled are relatively narrow-turning largely on who holds the relevant rights, how to assess damages, or certain other "legal" issues-tort law (supported by a court system) might be able to fill the breach. ${ }^{87}$ Where the gaps are broader and involve scientific or technical issues, other institutions, notably regulatory bodies, may emerge as a more effective way to answer fundamental information questions upon which the parties cannot agree. The need for some sort of external decisionmaking mechanism or "hierarchy" will be especially salient where the number of gaps, their complexity, or the divergence of values around them is great.

Tort law and courts might, therefore, be seen as a way to reinforce a market regime and to protect property rights, or as a first step toward an environmental regime based on "hierarchy." Liability rules, in particular, "collectivize" the damage assessment process and thereby reduce transaction costs and improve efficiency. Such an entitlement-protection regime changes the information dynamic, applying court-determined damages in place of negotiation between the parties. When a court fills the information gap that separates the parties,

86 Rose has demonstrated that a decision to "do nothing" may be the optimal response to some environmental harms. Id. at 9,17-18. This Article addresses the "do nothing" option in infra Part IV.F.

87 But note that courts have trouble making such assessments as well. See Krier \& Schwab, supra note 3 , at 453-55. 
it overcomes by fiat the potential negotiating breakdown over valuation of the harm in question. ${ }^{88}$

Just as the shift from property rules to liability rules achieves efficiency gains in some circumstances by replacing individual damage claims with court-determined awards, moving to command-and-control regulation further "collectivizes" the environmental decisionmaking process. In particular, responsibility for filling the full spectrum of information gaps falls to the government.

Centralizing the job of gap filling offers potential efficiency gains in several respects. Centralized data collection and analysis may generate economies of scale in the identification of pollution sources, the assessment of impact, and the valuation of harm. Because governments have an overarching perspective spanning a wide array of individual problems, they may be positioned to spot harms that individuals cannot see, recognize trends that might not be visible at a decentralized level, and make judgments about which interventions are most effective, on the basis of this broad experience. In addition, a governmental decisionmaking model economizes on information costs through repetition and learning. When regulators address similar problems again and again, they learn from experience, build a base of knowledge, and acquire some efficiency in overcoming uncertainties and filling information gaps.

Regulatory decisionmaking also changes the scale of environmental analysis by substituting average emission exposures and generalized cost-benefit calculations for individualized evaluation of exposures, impacts, and harm valuation. As a matter of institutional design, regulation implies that the optimal specificity of analysis is not on a case-by-case basis, but rather on a more generic, communitywide scale. Obviously, this shift in scale implies a tradeoff. In return for lower administrative costs, society accepts a loss of individual focus and fine-grained intervention to right specific environmental wrongs. In effect, the regulatory model accepts the judgment that the transaction costs involved in case-by-case evaluations of environmental harms are not justified by the benefits of individualized decisionmaking, and that we do better to internalize externalities broadly.

Agencies nevertheless must consume significant resources tracking, analyzing, and responding to environmental harms. They either must undertake quite detailed studies, which allow them to

88 Analogous to Calabresi and Melamed's structuring of rules to impose liability on the "cheapest cost avoider," I argue that environmental law and regulation should be structured to impose data and information-generation burdens on the "least-cost information provider." See Calabresi \& Melamed, supra note 2, at 1119; see also supra notes 55-56, 65, and infra note 234 and accompanying text. 
reduce the "failure costs" of over- or under-regulation, or they must employ information gap filling shortcuts, which reduce administrative costs but inflict inefficiencies on society in the form of misspecified environmental standards. ${ }^{89}$ A statutory approach to environmental problemsolving often authorizes regulators to look for generalized patterns of emission and harm, and to assert a causal nexus between pollution and injuries where the particularized facts might have been too limited to support a legal claim under the law of tort.90 The greater the heterogeneity of the regulated community and the problem set, the larger will be the likely policy errors from regulatory shortcuts. ${ }^{91}$ Precision is sacrificed for administrative convenience. ${ }^{92}$

The desire for improved precision has led to the development of hybrid institutional structures or "market-based" regulatory mechanisms. These approaches blend some elements of hierarchical gap filling with efforts to decentralize the information generation process and to harness market forces to draw out information from private parties. In essence, hybrid institutional designs shift some parts of the gap-filling process back onto the regulated community, recognizing that government may not be the least-cost information provider. Market mechanisms such as environmental taxes, pollution allowance trading systems, and deposit-refund schemes also reflect a judgment that the shift from a particularized scale of analysis to a generalized one may not always be welfare-enhancing.

An even broader shift of information-gathering and decisionmaking responsibility occurs when environmental protection is done on a "voluntary" basis. ${ }^{93}$ Where harm-causers act on their own to

89 By misspecified standards, I mean that the marginal costs and benefits of intervention are not optimally calibrated.

90 See John Copeland Nagle, CERCLA, Causation, and Responsibility, 78 MinN. L. REv. 1493 (1994) (discussing "uneasy coexistence" between CERCLA and causation).

91 See Robert Mendelsohn, Regulating Heterogeneous Emissions, 13 J. ENVTL. ECon. \& MGMT. 301 (1986) (demonstrating that greater heterogeneity leads to higher welfare losses from standardized policies).

92 See Diver, supra note 54, at 66-71 (demonstrating that increased regulatory specification comes at cost of reduced congruence or accessibility of rule).

93 See World Res. Inst., Beyond Compliance: A New Industry View of the ENvironment (Bruce Smart ed., 1992) (detailing reasons behind and results of voluntary environmental efforts of twenty-four companies); Jody Freeman, Collaborative Governance in the Administrative State, 45 UCLA L. REv. 1 (1997) (examining collaborative approaches to environmental protection). It is important to note that not all "voluntary" actions are truly voluntary. Some such actions are taken in response to consumer demands and should be seen, therefore, as an institutional offshoot of the marketplace. Others represent efforts to forestall regulation, such as the EPA's $33 / 50$ "voluntary" toxics reduction initiative. See Thomas P. Lyon \& John W. Maxwell, "Voluntary" Approaches to Environmental Regulation: A Survey, in ECONOMIC Institutions AND ENVIRONMENTAI Policy (Maurizio Franzini \& Antonio Nicita eds., 2002) (describing 33/50 program); see 
internalize externalities without Coasean bargaining or orders from courts or regulatory agencies, an array of gap-filling costs can be reduced or eliminated. As Ellickson and others have noted, community pressures, prevailing norms, and social context motivate some potential harm causers to control their emissions or limit their consumption of shared natural resources, reducing the need for contractual negotiations or external regulatory hierarchies. ${ }^{94}$ The potential savings to governments make reliance on the pressures of social context and polluter accountability a major policy trend.

The EPA's 33/50 toxic emissions reduction challenge represents a successful effort to induce voluntary environmental improvements. ${ }^{95}$ The success of recycling campaigns all across America offers another example of how the social context of environmental stewardship changes behavior. ${ }^{96}$ But how far society can go in relying on social context is a matter of debate; reliance on voluntary programs means that the government gives up the ability to specify performance standards. ${ }^{97}$ Moreover, the strength of the social pressure to control pollution varies across industry groups, geographic locales, political climates, and over time. ${ }^{98}$

generally Virginia Haufler, A Public Role for the Private Sector: Industry Self-Regulation in a Global Economy 31-51 (2001) (explaining logic of corporate self-regulation with regard to environmental issues); Seema Arora \& Timothy N. Cason, An Experiment in Voluntary Environmental Regulation: Participation in EPA's 33/50 Program, 28 J. EnVTL. ECON. \& Mgmt. 271, 273-75 (1995).

94 Robert C. Ellickson, Order Without Law: How Neighbors Settle Disputes (1991) (demonstrating that norms may be widespread and powerful even without force of law); see also Elinor Ostrom, Governing THE Commons 88-91, 205-07 (1990) (noting that individual members of homogenous communities are likely to conform their behavior to narrowly defined norms of propriety held by community); ERIC A. POSNER, LAW AND Social Norms (2000) (proposing methodology for systematic analysis of relationship between legal and nonlegal mechanisms of cooperation).

95 See Office of Pollution Prevention and Toxics, U.S. Envtl. Prot. Agency, Pub. No. EPA-745-R-99-04, 33/50 Program: The Final Record (1999) (finding that 33/ 50 program achieved its goal of fifty percent reduction in releases and transfers of seventeen targeted chemicals one year ahead of schedule).

96 See Office of Solid Waste and Emergency Response, U.S. Envtl. Prot. Agency, Pub. No. EPA-530-R-02-001, Municipal Solid Waste in the United States: 2000 FACTS AND FIGURES 123-25 (2002) (reporting growth in recycling), available at http:// msw.cecs.ucf.edu/MSW\%202000.pdf (last visited Feb. 23, 2004); see also WorLDWATCH Inst., Paper 121, The Next Efficiency Revolution (John E. Young \& Aaron Sachs eds., 1994) (reviewing recycling efforts).

97 See Andrew J. Hoffman, Institutional Evolution and Change: Environmentalism and the U.S. Chemical Industry, 42 ACAD. MGMT. J. 351 (1999) [hereinafter Hoffman, Institutional Evolution]; Andrew J. Hoffman, Trends in Corporate Environmentalism: The Chemical and Petroleum Industries, 1960-1993, 9 Soc'y \& NAT. Resources 47 (1996) [hereinafter Hoffman, Trends in Corporate Environmentalism].

98 The second Bush Administration seems to have created a particularly strong downdraft in this regard. See Robert Perks \& Gregory Wetstone, Rewriting the Rules, Year End Report 2002: The Bush Administration's Assault on the Environment 
Between fully voluntary programs and market-based regulation are "command-and-covenant" approaches to environmental protection. ${ }^{99}$ Popular in parts of Europe, a covenant strategy results in governments and regulated entities "contracting" for a certain degree of environmental protection, defined either by effort or outcome. ${ }^{100}$ Both sides in the negotiation have an incentive to pursue cost-effective interventions. ${ }^{101}$ As with market mechanisms, "command-andcovenant" approaches allow for some of the information burden to be shifted off the government and for a greater degree of case-specific data to be brought to bear.

The set of core institutional options for addressing environmental problems therefore includes:

(1) contractual exchange;

(2) tort liability;

(3) regulation -

(a) command-and-control mandates;

(b) market-based mechanisms;

(c) command-and-covenant procedures; and

(4) social context.

Given the diversity of pollution control and natural resource management challenges and the concomitant array of action, inaction, and transaction costs, it is unlikely that any single institutional strategy will produce optimal results. Mixed strategies and a mix of institu-

(2003) (finding "diverse and far-reaching Bush administration regulatory initiatives to cripple key environmental programs"). But see Andrew Goldstein \& Matthew Cooper, How Green is the White House?, TIME, Apr. 29, 2002, at 30 (arguing that the Administration is "greener than the environmentalists admit. But it still rolls out the red carpet for corporations.").

99 See E. Donald Elliott, Toward Ecological Law and Policy, in THINKING EcologiCALLY, supra note 31, at 170, 183-85 (explaining how "command-and-covenant" approach allows flexible compliance with existing benchmark standards).

100 See Environmental Contracts and Covenants: New Instruments for a Realistic Environmental Policy? 1-3, 5-12 (Jan M. Van Dunne ed., 1993); Jan W. Biekart, Environmental Covenants Between Government and Industry: A Dutch NGO's Experience, 4 Rev. Eur. Community \& INT'L ENvTL. L. 141 (1995) (reviewing covenants in Netherlands from perspective of NGO and discussing whether covenants can serve public interest in environmental protection); Eric W. Orts \& Kurt Deketelaere, Introduction: Environmental Contracts and Regulatory Innovations, in ENVIRONMENTAL CONtracts: Comparative Approaches to Regulatory Innovation in the United States And Europe 1, 5-11 (Eric W. Orts \& Kurt Deketelaere eds., 2001) (summarizing origin and practice of environmental contracting in European countries).

101 E. Donald Elliott \& Gail Charnley, Toward Bigger Bubbles: Why Interpollutant and Interrisk Trading are Good Ideas and How We Get There from Here, F. APPLIED Res. \& Pub. POL'y, Winter 1998, at 48, 50-52 (arguing that, even where it is difficult to measure risks exactly, "bubbles" still can reduce harm more effectively than command-and-control regulation). 
tions likely will be required. ${ }^{102}$ Indeed, a good bit of recent "regulatory reform" can be seen as an effort to find the optimal mix of institutions and strategies to minimize misspecification costs, reduce transaction costs, and otherwise optimize the $A+I+T$ calculus spelled out above. ${ }^{103}$

As the discussion above makes clear, the choice of institutional design can shift the burden of information production. Table 3 highlights the information generation responsibilities that emerge under various institutional options.

Coasean contracting requires the parties-polluters and victims-to generate much of the information that is required in order to negotiate successful outcomes. Tort law shifts a small part of this burden to the courts, notably with regard to rights delineation and damages assessment. Command-and-control regulation places virtually the entire information burden on the government. Market-based regulatory approaches draw the harm-causers back into the process at the stage of evaluating intervention options and implementing pollution controls. Command-and-covenant strategies create incentives to further lure the polluter into the information generation process. And voluntary programs can be seen as a nearly complete shift of information responsibility onto polluters.

Any regulatory reform and institutional design effort should therefore focus in part on identifying systematically the least-cost information generator for each potential gap spelled out in Table 1. Too many recent efforts seem to have been aimed narrowly at deregulation or simply reducing reliance on government information production. Future reform initiatives should be more attentive to who bears information-generating responsibilities, and whether they are positioned optimally to generate the data and analysis required to achieve least-social-cost outcomes.

\section{B. Rethinking Ends as Well as Means}

Information requirements not only determine our institutional design choices, but they also define the possible ends of environmental law. Indeed, the panoply of information gaps that must be confronted to address industrial-scale pollution has led to a narrowing

102 See Neil Gunninghan et al., Smart Regulation: Designing Environmental Policy 15-16 (1998) (arguing for mix of policy instruments).

103 See, e.g., DAviES \& MAZUREK, supra note 5, at 287-98 (arguing that "[t]he future system should be results-oriented, integrated, efficient, participatory, and informationrich"); Landy et al., supra note 5; Nat'l ACad. of Pub. Admin., Setting Priorities, Getting Results: A New Direction for the Environmental Protection Agency 1-5 (1995). 


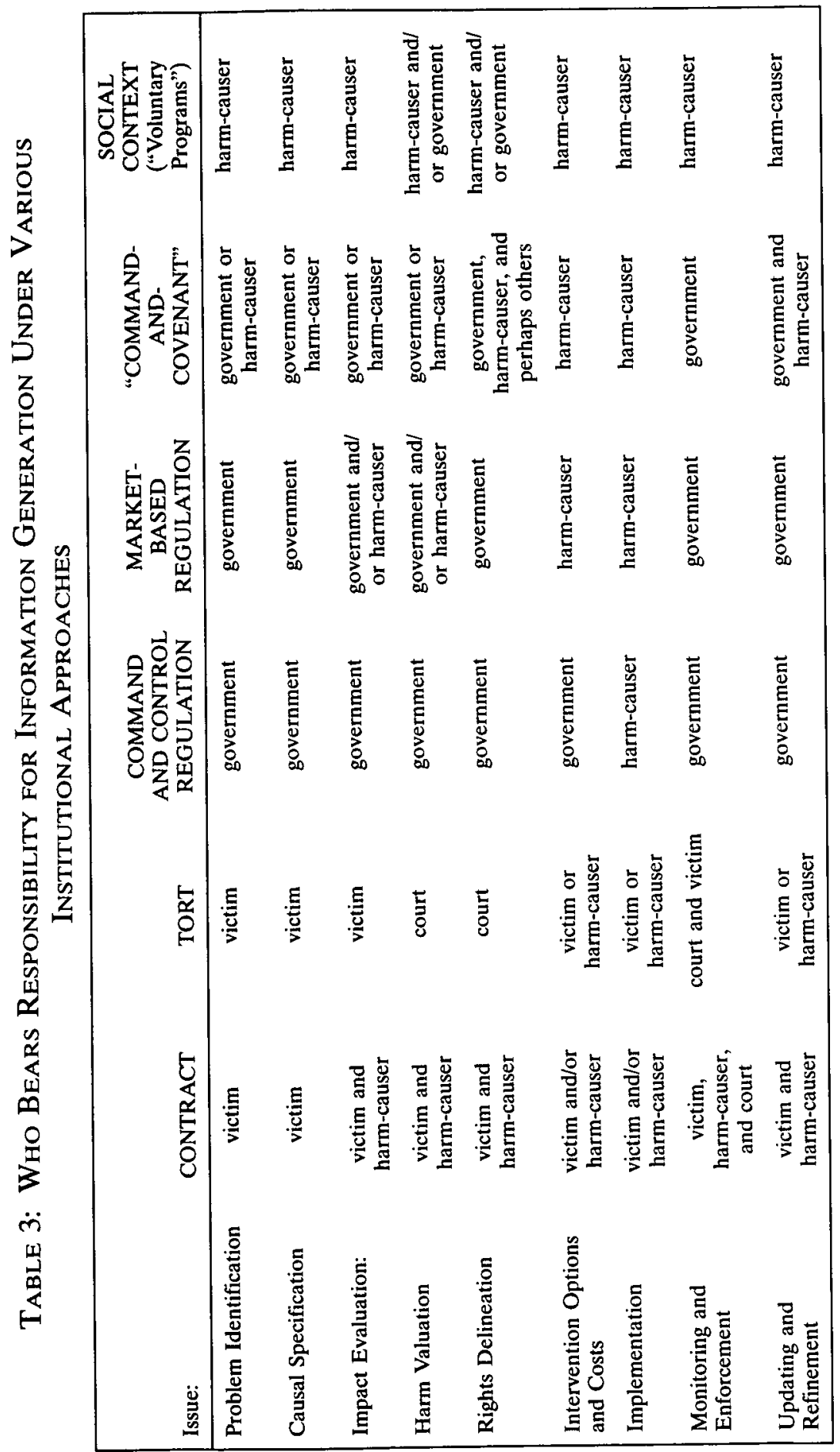


of our environmental vision. The present environmental regime seeks to internalize externalities in a least-social-cost manner, but ignores (1) the traditional (tort law) goal of making victims whole and (2) the reality that some pollution problems are understood better as inefficiencies or mistakes, not as externalities.

\section{Corrective Justice}

If pollution harms and the economic gains from the activities that generate them were distributed evenly across all citizens, pollution could be conceptualized as a tax on economic activity paid in terms of public health and ecological effects. Under this conception, it would be rational to apply a strict cost-benefit test to all regulation and to argue against intervention to address emissions whenever the economic benefits of the polluting activities exceed the gains from pollution abatement. But if the harms fall disproportionately on a subset of citizens, the pollution burden appears less like a tax and more like a taking, where some individuals have their property-in this case their "environmental" rights to breathe fresh air and drink clean waterseized to fund a community benefit. Conceived this way, social welfare still may be maximized by letting harms fall as they may, but this optimization comes at the expense of private property rights and individual justice.

Perhaps because the transaction costs of making victims whole are perceived to be too high, environmental decisionmaking in an information-constrained world tends to deemphasize corrective justice in favor of a focus on least-social-cost outcomes and efficiency. ${ }^{104}$ An emphasis on efficiency rather than protection of individual property rights comes through especially strongly in "law and economics" scholarship. ${ }^{105}$ But if information costs are reduced significantly, this tradeoff ought to be reexamined.

104 Even Rose, who argues that property is the "keystone" right, takes for granted that least-social-cost efficiency is the fundamental goal in the environmental realm. See Carol M. Rose, Property as the Keystone Right, 71 Notre Dame L. Rev. 329 (1996); Rose, supra note 85 , at $12-14$.

105 In elevating efficiency above other goals, "law and economics" scholarship often under-attends to the protection of property rights and the need to make victims whole. An emphasis on internalizing externalities in a least-social-cost manner translates into a utilitarian approach to policymaking that tends to crowd out corrective justice as a policy goal. Calabresi and Melamed, for example, relegate justice concerns either to an element of efficiency based on protecting expectations, or to a distributional issue that should be separately addressed. Calabresi \& Melamed, supra note 2, at 1105,1123 . Calabresi recognizes this point but still is known better for his emphasis on efficiency. See Calabresi, supra note 1, at 1224-28 (noting that distributional analysis becomes inevitable and hence essential); cf. Jules L. Coleman, Markets, Morals and the Law 184-201 (1988) (advancing a "theory of torts based on the principle of corrective justice"); Frank I. Michelman, Pollu- 
Consider, for example, a town with 1000 residents and a polluting factory where each resident suffers a pollution harm valued at $\$ 1$. Two distinct goals of governmental intervention can be identified. First, from the perspective of resource optimization, we want the polluter to face the costs of the factory emissions. Otherwise, the factory's production will be inefficient. Thus, for the sake of allocative efficiency, we would like to internalize the pollution externality by making the factory pay for the $\$ 1000$ worth of harm it is causing. Second, for the sake of corrective justice, we would like to make the pollution victims whole by giving them each $\$ 1$.

Under command-and-control regulation, these two goals seem to be in conflict. The factory faces government requirements (either technology mandates or performance standards) to reduce emissions by some amount. Rational regulators, operating in a fashion that promotes least-social-cost outcomes, will push to reduce emissions to the point where the marginal costs of further regulation would exceed the marginal benefits. But this standard likely leaves emissions above zero, imposing residual pollution harms on the residents. Although regulatory efficiency has been achieved, full cost internalization has not because some uncompensated harms continue to be borne by the residents. This means that neither the goal of allocative efficiency nor the goal of corrective justice has been met.

Alternatively, under a market-based pollution control regime, the regulators might charge the company for its emissions. By carefully setting pollution fees, they could induce the company to reduce its emissions to the point where the marginal cost of additional controls would exceed the marginal benefit in reduced fees. The company would then pay for its residual emissions and the harm they cause. This would fully internalize the pollution externality and produce an allocatively efficient outcome. If the town collects the fees, and thereby offsets taxes the residents would have borne, the victims would also be made whole. Under current practice, however, the pollution fees would be kept by state or federal authorities so the local victims-who actually bear the harms-would not be fully compensated. ${ }^{106}$

tion as a Tort: A Non-Accidental Perspective on Calabresi's Costs, 80 YALE L.J. 647, 649, 666-83 (1971) (book review) (critiquing Calabresi's approach). A full discussion about "taking environmental rights seriously" will have to be deferred to another day and another article. But note that a cramped conception of justice seems inconsistent with an insistence that liability rules must not be applied to crimes against property or bodily integrity. See Calabresi \& Melamed, supra note 2, at 1124-27. Why don't pollution "assaults" fall into this category?

106 If the fees are shared across all citizens in the regulating jurisdictions, the town's residents would get only a tiny offset against taxes. 
This scenario is complicated further in the real world because not every citizen, even within the town, is similarly situated. A more realistic scenario would entail ten citizens (perhaps next-door neighbors) facing harms of $\$ 20$ each, a second tier of one-hundred citizens (nearby neighbors) facing $\$ 3$ each in harms, and the rest of the community suffering damages of just $50 \varnothing$ each. In this case, the $\$ 1000$ in pollution fees, even if absorbed by the local government as a tax offset, dramatically undercompensates the next-door neighbors who receive $\$ 1$ (in reduced taxes) but suffer harms of $\$ 20$, somewhat undercompensates the nearby neighbors who face harms of $\$ 3$ but receive just $\$ 1$, and overcompensates everyone else, as they receive $\$ 1$ but face harms worth only 50\%. Thus, under a scenario in which the harms are not spread equally, even a locally controlled, allocatively efficient pollution control regime fails to meet the corrective justice goal of making victims whole. It is this sort of scenario-e.g., underprivileged neighborhoods living in the shadow of chemical facilities in Louisiana's "cancer alley"-that raises real-world questions about "environmental justice."107

Why is the corrective justice dimension of environmental law and policy so often neglected despite the frequency with which environmental policy fails actually to compensate victims? Several reasons can be identified. First, distributional considerations may, at times, cut against a strict "polluter pays" principle. If those who bear disproportionate environmental damages (the next-door neighbors) are the most affluent members of the community, then a result that holds the pollution fee revenue as an offset against taxes will, in effect, improve distributional equity. But as an empirical matter, the equity argument generally goes the other way: Those who are undercompensated for pollution harms turn out to be poorer than the average. ${ }^{108}$

Alternatively, the disregard for individualized pollution harms may reflect a policy choice to promote industrialization and economic

107 For background on the concept of environmental justice, see generally CLIFFORD Rechtschaffen \& Eileen Gauna, Environmental Justice: Law, Policy, and Regulation (2002); Edwardo Lao Rhodes, EnVironmental Justice in America: A New Paradigm (2003); K.S. Shrader-Frechette, Environmental Justice: Creating Equality, Reclaiming Democracy (2002); Richard J. Lazarus, Pursuing "Environmental Justice": The Distributional Effects of Environmental Protection, 87 Nw. U. L. REv. 787 (1993).

108 See Vicki Been, Locally Undesirable Land Uses in Minority Neighborhoods: Disproportionate Siting or Market Dynamics?, 103 Y ALE L.J. 1383, 1384-85 (1994) (explaining that in addition to unfair siting, market forces cause environmental harms to fall disproportionately on poorer people); William Bowen, An Analytic Review of Environmental Justice Research: What Do We Really Know?, 29 ENVTL. MGMT. 3 (2002) (surveying numerous studies connecting poverty to disproportionate environmental harms). 
growth. ${ }^{109}$ Some scholars argue that neglect of pollution victims can be traced to the power of the nineteenth-century industrialist class, which constructed a legal regime that favored their economic interests. ${ }^{110}$ Still others conclude that justice considerations dropped out of the environmental equation as a result of utilitarian legal analysis ${ }^{111}$ or a judicial desire to promote wealth maximization. ${ }^{112}$

While all of these arguments are plausible and each represents part of the explanation for the minimal role corrective justice plays in our present day pollution control regime, I think another reason must be considered: the historically high cost of protecting environmental property rights on an individualized basis. Sorting out who has been harmed and how much each should be compensated has been considered too information-intensive. In my example, if the residual harm were $\$ 1$ per resident, but the transaction costs (largely information costs related to computing the harm, identifying the affected residents, and paying out compensation) were greater than $\$ 1000$, there would seem to be no point in going forward. The costs of intervention would exceed the benefits. This decision must be understood, however, as a choice to elevate welfare maximization over the protection of individual property rights and corrective justice.

Now consider how the picture changes if transaction costs decline dramatically. Assume that new pollution tracking technologies lower the expense of measuring the harm and delivering compensation from more than $\$ 1000$ to $\$ 1$. The cost-benefit logic flips in favor of intervention, and the option of paying out compensation to the victims becomes feasible. And what if we were able to determine precisely which residents were harmed and by how much, and could thus tailor the compensation payments to the precise level of harm each pollutee suffered? Would we not then want to provide collective justice tailored to individual damages alongside efficiency? To the extent that

109 See Morton J. Horwitz, The Transformation of American Law 1780-1860, at 97-108 (1977) (discussing how "triumph of negligence" acted as subsidy to industrialization); Herbert Hovenkamp, The Economics of Legal History, 67 MinN. L. Rev. 645, 670-78 (1983) (discussing "utilitarian" principles of nineteenth-century jurists).

110 E.g., Paul H. Rubin, Business Firms and the Common Law: The Evolution of Efficient Rules 27-30 (1983); Christine Rosen, Differing Perceptions of the Value of Pollution Abatement Across Time and Place: Balancing Doctrine in Pollution Nuisance Law, 1840-1906, 11 L. \& Hist. ReV. 303, 354-78 (1993).

111 Rosen, supra note 110, at 315-22 (arguing that utilitarian analysis has resulted in underattention to pollution).

112 See Richard A. Posner, A Theory of Negligence, 1 J. Legal Stud. 29, 32-36 (1972) (arguing that judges pursued efficiency goals even before economic logic of this posture was fully understood); Richard A. Posner, Wealth Maximization and Judicial DecisionMaking, 4 INT'L REV. L. \& ECON. 131, 133 (1984) (arguing that wealth maximization is only value that courts can do much to promote). 
the cost of compensation falls in the Information Age, this change in relative prices may revive interest in corrective justice by softening the apparent trade-off with economic efficiency.

\section{Beyond Externalities}

In the classic pollution situation, $B$ benefits from externalizing environmental harms onto his neighbor $A$ or the community at large. Benton saves money in his pig farming operation if he can dodge the burden of addressing the effluent and odors that emanate from his sty. ${ }^{113}$ The prevailing regulatory designs, therefore, focus on internalizing externalities. ${ }^{114}$ There are, however, a set of environmental problems that do not fit this model, where the harm arises from production or consumption inefficiencies or mistakes, not externalities per se. ${ }^{115}$

Think, for example, of cases where $B$ 's factory equipment is outdated and inefficient and, incidentally, highly polluting. If the plant were modernized, we might assume that efficiency benefits would flow to the factory's bottom line. $B$ does not need to be forced by law or regulations to internalize his externalities: $\mathrm{He}$ has an incentive to fix the problem regardless of the impact on $A$ or others. Those downwind of the polluting production process would incidentally benefit as increased resource productivity translates into reduced emissions. Why would $B$ fail to make the improvements? In some circumstances, $B$ fails to act because he believes he has better ways to deploy limited investment capital. In many other cases, however, $B$ 's inaction derives from inertia or ignorance-a basic lack of information about the better environmental options.

Such circumstances differ from the usual externality case because self-interest, at least over time, should drive $B$ to correct his mistake and adopt the environmentally preferable technology, product, or production process. ${ }^{116}$ Environmental policy in this context should center on addressing the information failure and providing guidance

113 Aldred's Case, 77 Eng. Rep. 816 (1611).

114 See Baumol \& OATES, supra note 14, at 7-35 (examining types of externalities and approaches for forcing internalization).

115 See Michael E. Porter \& Claas van der Linde, Toward a New Conception of the Environment-Competitiveness Relationship, 9 J. ECON. PERSP. 97, 106 (1995) (describing how improvements in "resource productivity" will align environmental improvement and competitiveness interests).

116 See Esty \& Porter, supra note 46, at 36-40 (discussing resource productivity opportunities available to companies). 
about better practices and potential efficiency gains rather than narrowly focusing on internalizing externalities. ${ }^{117}$

A great deal of attention in recent years has been paid to opportunities for such "win-win" environmental gains. ${ }^{118}$ A vigorous debate rages over how often polluters obtain net benefits from changing their own behavior. ${ }^{119}$ The truth is that investments in pollution control sometimes, but by no means always, pay off economically. Nonetheless, the mistake and inefficiency category of environmental problems deserves particular attention in the Information Age context because the cost of overcoming ignorance goes down. Easier and cheaper dissemination of information about the existence of better technologies and production practices promises to squeeze out inefficiencies and eliminate mistakes more quickly.

III

The Coming Revolution

The economic and social transformation being wrought by advances in information technology has been the subject of a vast amount of writing, both popular and scholarly. ${ }^{120}$ But little of this

117 Progress is likely only "over time" because of the need to depreciate existing capital investments and the "lumpiness" of investments in a new plant and equipment. To speed up the transition process, the government might highlight the better options and available efficiency gains. To ensure an optimal degree of investment in pollution control, $B$ 's decision process should be structured to reflect externalized pollution harms. But a pure "cost internalization" strategy will not highlight the potential gains within the enterprise from higher-efficiency, less-polluting equipment, and will systematically result in less new capital investment.

118 E.g., Al Gore, Earth in the Balance: Ecology and the Human Spirit 342 (1992) (pointing out existence of win-win opportunities such as 3M's "Pollution Prevention Pays" program); ERnst Ulrich Von Weizsäcker et al., Factor Four: Doubling Wealth - Halving Resource Use xxi-xxii (1997) (arguing that there are numerous opportunities in advanced resource efficiency that are both feasible and cost-effective).

119 Compare Porter, supra note 72 (advancing "Porter Hypothesis," which suggests that environmental investments may result in competitiveness gains), and Michael E. Porter \& Claas van der Linde, Green and Competitive: Ending the Stalemate, Harv. Bus. Rev., Sept.-Oct. 1995, at 120 (discussing how environmental rigor can generate innovation benefits), with Noah Walley \& Bradley Whitehead, It's Not Easy Being Green, HaRv. Bus. REV., May-June 1994, at 46 (suggesting that win-win gains are very limited in real world).

120 For a sampling, see generally Stanley H. Davis \& Christopher Meyer, Blur: The Speed of Change in the Connected Economy (1998); Michael L. Dertouzos, What Will Be: How the New World of Information Will Change Our Lives (1997); Kevin Kelly, Out of Control: The New Biology of Machines, Social System and the Economic World (1994); Lawrence Lessig, Code and Other Laws of Cyberspace (1999); Lawrence Lessig, The Future of Ideas: The Fate of the Commons in a Connected World (2001) [hereinafter Lessig, Future of Ideas]; Steven R. Salbu, Who Should Govern the Internet?: Monitoring and Supporting a New Frontier, 11 HARv. J.L. \& TECH. 429, 431 (1998) (discussing how technological growth is outpacing law's ability to respond); Spencer Reiss, Power to the People, WIRED, Dec. 1996, 
literature addresses the domain of pollution control and natural resource management. This Part seeks to provide an initial survey of how Information Age technologies might be deployed in the environmental realm and what impact they might have on our ability to fill the information gaps identified in Part II.

\section{A. The Environmental Promise of the Information Age}

Technological advances in data collection, analysis, and dissemination have the potential to revolutionize our response to environmental problems.

\section{Data Collection}

Environmental databases historically have been patchy, unreliable, and woefully inadequate to the needs of efficient decisionmaking. ${ }^{121}$ Breakthroughs in nanotechnologies and small-scale sensors, however, have begun to provide a vastly improved ability to detect and measure pollutants at a fine-grained level. ${ }^{122}$ Similarly, remote sensing from satellites in space ${ }^{123}$ and other new macroscale sensor technologies appear poised to provide on-the-ground monitoring of environmental conditions from anywhere, at any time, at

at 184, available at http://www.wired.com/wired/4.12/esgage.html (last visited Feb. 23, 2004).

121 See Davies \& MAzureK, supra note 5, at 269 ("There is a systematic underinvestment, in some cases a disinvestment, in the information-gathering efforts necessary to run an intelligent pollution control program."); LANDY ET AL., supra note 5, at 282-83 (arguing that EPA's data collection is marked by oversimplifications and arbitrary categorizations); MORGENSTERN, supra note 5, at 463-66 (discussing inadequacies in risk assessment models due to data limitation); see also World Econ. Forum, 2001 Environmental Sus. tainability Index: AN INITIATIVE of THE Global Leaders of Tomorrow ENviron. MENT TASK FORCE 17-22 (2001) (decrying lack of usable environmental data), available at http://www.ciesin.org/indicators/ESI/ESI_01a.pdf.

122 Some observers even forecast a time when humans could be outfitted with a "digital skin" that allows a precise record of pollution impacts to be generated. See H. Scott Matthews, Environmental Impacts and Policy Implications of the Growth of the Information and Communications Technology Sector 27-28 (unpublished manuscript, presented Mar. 16, 2001 at Org. for Econ. Co-Operation and Dev., Environment Directorate Workshop, Paris; on file with New York University Law Review).

123 See Anthony Vodacek, Environmental Applications of Remote Sensing, INFORMATIK/ INFORMATIQUE, Aug. 2000, at 21 (outlining various environmental uses for remote sensors); see also Fred Hansen, Three Emerging Issues, Three Needed Changes, EnvTL. F., May/June 2000, at 45, 46 (noting that remote satellite sensing will enable "identification with pinpoint accuracy of all emission discharges"); Alex de Sherbinin et al., Remote Sensing Data: Valuable Support for Environmental Treaties, 44 ENV'T 20, 22-25 (2002); Paul F. Uhlir, Applications of Remote Sensing Information in Law: An Overview, in Earth Observation Systems: Legal Considerations for the '90s 8, 16-17 (1990) (describing how remote sensing systems will lead to better ecological understanding and management). 
increasingly low cost. ${ }^{124}$ We thus are approaching the day when virtually all emissions will be susceptible to tagging, tracking, and measurement at relatively low cost. ${ }^{125}$

Air emissions already are being tracked with a degree of sophistication that was unimaginable just a few years ago. Gaussian plume analysis now permits regulators to plot the drift of air pollutants with increasing precision. ${ }^{126}$ Advances in meteorological modeling have further enhanced our ability to understand the sources and "receptors" of air pollution. Similar gains are being made in tracing pollutants as they flow through watersheds and hydrological systems. ${ }^{127}$

These advances in measuring and monitoring translate into muchimproved comprehension of exposure pathways, impacts, and doseresponse relationships. It may not be long before emissions sources will be nearly completely mapped, if not fully understood.128 As a leading toxicologist observes:

Admittedly, there are a large number of factors to consider when estimating exposure, and it is a complicated procedure to understand the transport and distribution of a chemical that has been released into the environment. Nonetheless, the available data indi-

124 The scientific literature is rich with examples of breakthroughs in sensors and monitoring technologies. See, e.g., Eric J. Hinsta et al., SPADE $\mathrm{H}_{2} \mathrm{O}$ Measurements and the Seasonal Cycle of Stratospheric Water Vapor, 21 GeOPHYSICAL Res. LETTERs 2559 (1994) (discussing new methods for measuring lower stratospheric water vapor); Christopher $\mathbf{R}$. Webster et al., Quantum-Cascade Laser Measurements of Stratospheric Methane and Nitrous Oxide, 40 ApPLIED Optics 321 (2001) (highlighting advances in laser technology allowing for first atmospheric gas measurements).

125 See Braden R. Allenby et al., Information Systems and the Environment: Overview and Perspectives, in Information Systems AND THE ENVIRONMENT, supra note 45, at 1 (noting pollution tracking potential of "information and communications revolution").

126 Such modeling has transformed the debate over the sources of air pollution in the northeastern United States. For an example of ozone modeling, see EnvTL. Prot. Agency, Final Report, Ozone Transport Assessment Group (OTAG) Technical SUPPORTING Document, http://www.epa.gov/ttn/naaqs/ozone/rto/otag/finalrpt (last visited Feb. 25, 2004).

127 Kurt Stephenson et al., Watershed-Based Effluent Trading: The Nonpoint Source Challenge, 16 CONTEMP. ECON. POL'Y 412, 415-18 (1998) (describing several programs successfully measuring movement of nonpoint source pollutants).

128 See Dennis J. Paustenbach, The Practice of Exposure Assessment: A State-of-the-Art Review, 3 J. Toxicology \& Envtl. Health 179 (2000) (chronicling extraordinary recent gains in understanding environmental risk exposures); see also Carl B. Meyer, The Environmental Fate of Toxic Wastes, The Certainty of Harm, Toxic Torts, and Toxic Regulation, 19 ENVTL. L. 321, 323-24 (1989) ("Toxic wastes can be fingerprinted; emission sources can be linked with the toxic residues found in the bodies of environmental injury victims; the extent of the accumulation of toxics in the environment can be predicted; and the body burden of toxic exposure victims can be measured with a high degree of scientific certainty." (citations omitted)); Jennifer Brown, Comment, Pediatric Environmental Health Hazards and the Role of Government in Adopting Standards to Protect Children, 16 PACE ENVTL. L. REV. 189, 197-202 (1998) (describing new national initiatives and research into effects of pediatric exposure to pollutants). 
cate that scientists can do an adequate job of quantifying the concentration of the chemicals in the various media and the resulting uptake by exposed persons . . . . 129

In combination with extraordinary new data production and collection in genomics ${ }^{130}$ and medicine, ${ }^{131}$ we stand on the verge of more scientifically robust answers to questions about how much harm pollutants cause to particular individuals.

\section{Analysis}

Environmental problemsolving long has been defined by the need to simplify issues to a level that humans can absorb and manage. ${ }^{132}$ The sheer computational power available today, however, changes this policy dynamic. ${ }^{133}$ Data is not just being collected more easily; it is being refined and processed in ways that generate firmer analytic foundations for environmental decisionmaking. ${ }^{134}$ Simply put, these gains in data management, analysis, and retrieval make possible a more empirical and quantitative approach to environmental protection.

Where sheer numerical quantity might once have overwhelmed analysts, computers now permit "data mining"-quick and efficient sifting of raw data. ${ }^{135}$ Useful information can be extracted even under

129 Paustenbach, supra note 128, at 264.

130 See generally Juan Enriquez, As the Future Catches You: How Genomics \& Other Forces are Changing Your Life, Work, Health \& Wealth (2001); Matt Ridley, Genome: The Autobiography of a Species in 23 Chapters (1999).

131 See, e.g., Solana Pyne, Small Particles Add Up To Big Disease Risk, 295 Scr. 1994 (2002) (analyzing mounting evidence of harms of air pollution to human health).

132 See Sunstein, Risk, supra note 53, at 667-70 (finding that informational strategies can be ineffectual if people "have limited ability to process information" or if "information is not provided in a clear and usable form"); see also Graham \& Wiener, supra note 19 (discussing lack of coherent system for measuring levels and trends of environmental risks, and pervasiveness of "risk tradeoffs").

133 See Bradley Efron, The Jackknife, the Bootstrap, and Other Resampling Plans 2-3 (2002) (highlighting gains made possible by expanded computing power and nonparametric methods for assessing errors in statistical estimation).

134 See Dashboard of Sustainability: Sustainable Development Indicators for the WSSD, at http://esl.jrc.it/envind/dashbrds.htm (last visited Feb. 23, 2004) (describing software that allows presentation of complex relationships between economic, social, and environmental issues); Org. Econ. Co-Operation \& Dev., Towards Sustainable DEVElopment: ENVIRONMENTAL InDICATORS (1998) (proposing uniform set of environmental indicators for OECD countries); Mathis Wackernagel \& William E. Rees, Our Ecological Footprint: Reducing Human Impact on the Earth (1996) (introducing "econological Footprint" analysis which accounts for flows of energy and matter to and from any defined economy and converts them into corresponding land/water area required to support these flows); see also World Econ. Forum, 2002 ENvironmental SUSTAINABILITY INDEX (2002), available at http://www.ciesin.columbia.edu/indicators/esi/.

135 Recent computational advances have vastly increased the power of many statistical techniques. See, for example, the websites of the IEEE Neural Network Society, http:// 
conditions that present very high noise-to-signal ratios. ${ }^{136}$ Advanced statistical techniques, such as neural nets, ${ }^{137}$ facilitate sophisticated pattern recognition and issue analysis. ${ }^{138}$

Without eliminating all of the uncertainties, computers make it possible to fill data gaps in a systematic and sophisticated manner and to respond better to problems that involve multiple variables. As it becomes ever faster, easier, and cheaper to sort, store, and analyze data, the boundaries of learning are being pushed out at an accelerating rate. ${ }^{139}$ The sweeping potential for improved causal specification derives not only from new analytic tools developed in the environmental field, but also from the computer-enabled knowledge revolution occurring within other disciplines, including public health, epidemiology, hydrology, statistical modeling, and risk-benefit analysis. ${ }^{140}$

Perhaps most importantly, enhanced tools for data analysis make it easier to manage complexity. Cumulative impacts and synergistic effects of emissions become easier to disentangle. Likewise, the interactions that underlie natural resource management become easier to disaggregate. Ecologists, for example, are learning how timbering

ieee-nns.org/research/nnpubs.html, and the International Neural Network Society Journal, http://www.inns.org/nnjournal.asp, for a sampling of the literature on the latest computeraided advances in neural networking and its widely expanded commercial applications. See also Envtl. Prot. Agency, Statistical Primer, at http://www.epa.gov/ bioindicators/primer/index.html (last updated Aug. 2, 2002) (detailing EPA's efforts to apply regression analysis and other recent advances in statistical modeling techniques to aquatic resources and biodiversity management).

136 See Trevor Hastie et al., The Elements of Statistical Learning: Data Mining, InfEREnCE, AND Prediction (2001) (describing application of modern statistical techniques for sorting data); Michael Goebel \& Le Gruenwald, A Survey of Data Mining and Knowledge Discovery Software Tools, 1 SIGKDD EXPLORATIONS: NEWSLETTER OF The ACM Special Interest Group on Knowledge Discovery and Data Mining 20 , 23 (1999) (describing certain "noise tolerant" data mining methodology), available at http://www.acm.org/sigkdd/explorations/issue1-1/survey.pdf.

137 Simon Haykin, Neural Networks: A Comprehensive Foundation 1-6 (1999) (explaining advanced statistical technique of pattern recognition); Ian R. Kerr, Spirits in a Material World: Intelligent Agents as Intermediaries in Electronic Commerce, 22 DALHOUSIE L.J. 190, 208 (2001) (describing how neural nets work).

138 See Sergios Theodoridis \& Konstantinos Koutroumbas, Pattern RecogniTION (1999) (explaining neural networks, rule learning systems, and statistical analysis).

139 See generally Nicholas Negroponte, Being Digital (1995) (reviewing Digital Age breakthroughs).

140 Researchers at the Harvard School of Public Health, for example, are using advanced computer modeling to assess better the health impacts of air pollution. See Study Details Impact of Pollution on Public Health from Nine Older Fossil Fuel Power Plants in Illinois, at http://www.hsph.harvard.edu/press/releases/press01032001.html (last visited Feb. 23, 2004); see also Deborah Schoen, A Renaissance for Genotoxicity Testing?, 32 EnvTL. SCIENCE \& TECH. 498A (1998) (discussing techniques to investigate effects of various toxics on humans and other organisms). 
practices, such as clear-cutting, affect levels of sunlight on wetlands, which in turn affect habitat productivity and thus species diversity. ${ }^{141}$ As a general matter, while the complexity of the environmental realm will not diminish, our ability to make sense of what is going on and to tailor policy responses to particularized circumstances appears likely to increase rapidly, improving our capacity to fill information gaps in problem identification, causal specification, impact evaluation, and policy intervention. ${ }^{142}$

\section{Dissemination}

As a number of observers have noted, wireless communications and the Internet portend the "end of distance" and the "collapse of time." 143 Connection speeds are increasing at a dramatic pace while the cost of communications is falling rapidly. ${ }^{144}$ Links to virtually anyone on the planet, or to data sets anywhere in the world, are now available at any time at very low cost. These communications breakthroughs represent another dimension of the Information Age with potentially important environmental applications.

One of the most striking features of the Internet is its capacity for speedy and low-cost dissemination of information. Advances in environmental understanding thus can be transmitted immediately across the world. Hyperconnectivity changes the cost of establishing an appropriate technical foundation for environmental decisionmaking. ${ }^{145}$ Relevant information-details about on-the-ground conditions, answers to many scientific questions, and data on how others

141 E.g., M.A. Halverson et al., Forest Mediated Light Regime Linked to Amphibian Distribution and Performance, 134 Oecologia 360 (2003).

142 The ability to manage complexity allows decisionmakers to understand and address anomalous circumstances and optimize "slippage" from general rules. See Daniel A. Farber, Taking Slippage Seriously: Noncompliance and Creative Compliance in Environmental Law, 23 HARv. Envtl. L. Rev. 297, 315-25 (1999); see also Farber, supra note 23 (applying complexity theory in environmental realm); Dennis D. Hirsch, Project XL and the Special Case: EPA's Untold Success Story, 26 Colum. J. EnvtL. L. 219, 256-57 (2001) (arguing that informational advances from rigorous evaluation of experimental projects may reduce need for waivers from general rules).

143 See generally Douglas F. Aldrich, Mastering the Digital Market Place: Practical Strategies for Competitiveness in the New Economy 31-32 (1999) (highlighting time impacts of digital breakthroughs); MitCHELl, supra note 8 , at 15-20 (explaining how information technologies reduce time and distance). The costs of overcoming time and distance have often precluded potentially useful information from being brought to bear on environmental problems.

144 Indus. Analysis Div., Fed. Communications Comm'n, Trends in Telephone SERVICE 14-5 (2000) (charting price drop of directly dialed five-minute long-distance calls for certain calling distances).

145 See Joshua Knauer \& Maurice Rickard, Internet Global Environmental Information Sharing, in INFORMATION SYSTEMS AND THE ENVIRONMENT, supra note 45, at 185, 187-89 (highlighting declining cost of environmental information sharing). 
have dealt with particular issues-becomes much more readily available. ${ }^{146}$ Internet-based tools, such as the emissions "scorecard" created by Environmental Defense, increasingly put key data at anyone's fingertips. ${ }^{147}$ Just as computers facilitate the information collection and analysis that makes a more data-driven approach to environmental protection possible, digital communications systems (and particularly the network structure of the Internet) allow access to vast quantities of "distributed information" that would previously have been unobtainable or unsearchable in a cost-effective manner. ${ }^{148}$ In so doing, they expand the pace of both knowledge exchange ${ }^{149}$ and the generation of new ideas or tools to address environmental harms. ${ }^{150}$

146 More plentiful and less expensive information does not guarantee that unprocessed data will be translated into usable knowledge. We can analogize to manufacturing: Data is the raw material. Information is the intermediate good, reflecting some processing of the data. Knowledge is the final product. To move from data to substantive content requires a rigorous scientific process of developing and testing hypotheses, careful analysis, systematic quality controls, and sensitivity analysis to highlight the effects of remaining uncertainties.

147 The Environmental Defense interactive Scorecard site invites visitors to "just enter your zip code and find out what pollutants are being released into your community-and who is responsible." See Envtl. Def., Scorecard, at http://www.scorecard.org (last visited Feb. 26, 2004). The EPA provides results of its annual Toxic Release Inventory (TRI) online in very accessible formats, including state fact sheets, public data releases, state data files, and searchable databases. Envtl. Prot. Agency, Toxic Release Inventory ProGRAM, available at http://www.epa.gov/tri/tridata/index.htm (last visited Feb. 13, 2004). Indonesia's PROPER toxics disclosure system shows that these gains can be extended to the developing world. See Shakeb Afsah \& Jeffrey R. Vincent, Putting Pressure on Polluters: Indonesia's PROPER Program, A Case Study for the HIID 1997 Asia Environmental Economics Policy Seminar (1997), available at http:// www.worldbank.org/nipr/work_paper/vincent/vincent.pdf.

148 See Mitchell, supra note 8, at 13-21 (discussing time, space, transportation, and coordination efficiencies gained from digital networks); see also Dan Taylor, Environment and Infrastructure: How We Can Use Information Technology to Avert Another Tragedy of the Commons, IMP: The MAG. ON INFo. IMPACTS, Oct. 1999, at http:// www.dantaylor.com/insights/water-tragedy.html (proposing Internet-based management monitoring system for Great Lakes); A. Voinov \& R. Costanza, Watershed Management and the Web, 56 J. EnvTL. Mgmt. 231 (1999) (showing how Internet can advance and improve watershed management).

149 See Ramamurti Shankar, Globalization and Science: A Speeded-up Virtuous Cycle, YaleGlobal Online, Mar. 28, 2003, at http://yaleglobal.yale.edu/display.article?id=1259 ("For scientists all over the world, the internet and electronic publication revolution have proved a boon-expanding the areas of research and accelerating the pace of knowledge exchange.").

150 See Greg Pitts \& Jerry Fowler, InfoSleuth: An Emerging Technology for Sharing Distributed Environmental Information, in INFORMATION SYSTEMS AND THE ENVIRONMENT, supra note 45, at 159 (describing Environmental Data Exchange Network's InfoSleuth technology and its ability to fuse data from multiple sources). 


\section{B. A Reshaped Environmental Decisionmaking Context}

While the pace of technological change itself gives reason to question our assumptions about persistent information gaps, even more compelling are the environment-specific applications of new technologies. This Section explains how information technology gains will improve the visibility of pollution harms and natural resource problems, enhance environmental modeling and predictive capacity, enable greater quantification of policy choices, and promote transparency and the democratization of policymaking.

\section{Visibility of Harms}

Information Age technologies make the invisible visible in a variety of ways. Combining the advances in data collection described above with improved computing power that permits scientists to extract usable information from vast data sets gives us the capacity to "see" many environmental problems more clearly. Cancer clusters, for example, can now be found in public health data that was previously unintelligible. ${ }^{151}$ In the realm of natural resource management, the data-aggregation capacity of computers has proven to be especially helpful in spotting "tragedies of the commons" at earlier stages, where the impact of individual behavior is minute. A single fisherman or fishing boat seemingly has no effect on fish stocks, for example, but fishing fleets collectively can deplete entire fisheries if the aggregate catch is not tracked from an overarching perspective. ${ }^{152}$

Improved data collection and computer-supported analytic capacities are especially helpful in revealing diffuse harms that spread across space or time. The downwind impacts of sulfur dioxide emissions from the tall smokestacks of power plants now are recognized, despite being highly dispersed, because better data collection and analysis reveals patterns of respiratory distress, acidification of lakes, and other harms. Even greenhouse gas emissions, which spread spatially across the planet and inter-temporally across generations (persisting in the atmosphere for as long as several centuries) now can be measured carefully and increasingly understood. ${ }^{153}$

As noted earlier, many pollutants mix in ways that have proven difficult to untangle, making problems hard to bring into focus. Air

151 See, e.g., Susan D. Richardson et al., Identification of Drinking Water Contaminants in the Course of a Childhood Cancer Investigation in Toms River, New Jersey, 9 J. ExPOSURE ANAlysis \& ENVTL. EPIDEMIOlogy 200 (1999).

152 Michael De Alessi, Fishing for Solutions, IEA Stud. On Env'T., Nov. 11, 1998, at $40-43$.

153 See Intergovernmental Panel on Climate Change, supra note 74, at 17 (discussing advances in assessment of impacts, vulnerabilities, and adaptation). 
pollution, for example, represents a complex "soup" derived not only from millions of cars and trucks emitting particulates, $\mathrm{NO}_{\mathrm{x}}$, carbon monoxide, volatile organic chemicals (VOCs), and other byproducts of combustion in their exhaust, but also emissions from thousands of individual homes, factories, and commercial facilities. With the help of modern sensors and information management systems, it is now possible to identify the separate "ingredients" of air pollution. ${ }^{154}$

Additional "realization" gains have come from advances in the visual display of information. ${ }^{155}$ While no one could see the ozone layer thinning, computer-generated representations of the expanding Antarctic ozone hole helped to induce global action in response to the release of CFCs and other ozone-depleting chemicals. ${ }^{156}$ In fact, one of the areas of greatest promise from a more data-driven approach to environmental protection is the ability to overcome cognitive failures that have plagued problem identification and policymaking. ${ }^{157}$ Indeed, from the dawning of the Enlightenment to the present day, a fundamental tenet of science and intellectual inquiry more broadly is the belief that better evidence (particularly empirical support) will yield better answers to questions. ${ }^{158}$ As John Stuart Mill famously observed, "Wrong opinions and practices gradually yield to fact and argument." 159

154 See supra notes 121-26 and accompanying text.

155 See Edward R. Tufte, The Visual Display of Quantitative Information (1983) (demonstrating how sophisticated data displays can change perception).

156 See Benedick, supra note 61 , at 18-22.

157 See Cass R. Sunstein, The Laws of Fear, 115 HARv. L. Rev. 1119, 1150-52, 1168 (2002) (reviewing Paul Slovic, The Perception of Risk (2000)) (critiquing Slovic's conception of psychiatric paradigm and instead explaining divergence between experts' and lay people's evaluation of risk in terms of accessibility to "off-screen" data); Sunstein, supra note 19; see also Jeffrey J. Rachlinski, The Psychology of Global Climate Change, 2000 U. ILL. L. REv. 299, 303-13 (arguing that powerful social and cognitive limitations prevent the international community from working collectively to combat global warming); Rachlinski \& Farina, supra note 19, at 558-60 (explaining why regulatory "experts" nonetheless fall prey to heuristic shortcuts that contribute to inferior policy choices).

158 See D. Kabraman, Modeling Facts, Culture, and Cognition in the Gun Debate 4-7 (unpublished paper presented at the Yale Law School, Nov. 15, 2003; on file with New York University Law Review) (explaining logic and foundations of the "factual Enlightenment model"); see also Dennis v. United States, 341 U.S. 494, 550 (1951) (Frankfurter, J., concurring) ("The history of civilization is in considerable measure the displacement of error which once held sway as official truth by beliefs which in turn have yielded to other truths."). See generally KARL R. POPPER, The Defence of Rationalism, in POPPER SELEC. TIONS 33 (David Miller ed., 1985).

159 John Stuart Mill, ON Liberty 21 (David Spitz ed., 1975) (1859). But see D. Kabraman, supra note 158, at 4, 13 (arguing that "cultural cognition constrains factual enlightenment" and that individual's belief formation process and acceptance of "facts" is constrained by his values). 


\section{Modeling and Prediction}

Computer modeling narrows the range of uncertainties related to pollution impacts and causal pathways that have plagued environmental policymaking on all levels. Better forecasting allows potential problems to be spotted before they emerge and helps to target policy interventions. The examples are manifest. Regulators now plot the drift of particulates, smog, and other air pollutants with a degree of precision unheard of just a few years ago. ${ }^{160}$ Likewise, foresters increasingly can project the sustainable yield from a timber stand. ${ }^{161}$ And fisheries now are being managed with models that help to specify what constitutes a sustainable yield from a particular stock. ${ }^{162}$

Similarly, genetic algorithms make it possible for decisionmakers to model policy options and combinations of options, forecasting results in a matter of hours rather than waiting years for actual results to emerge. The evolutionary process of policy evaluation and refinement through trial and error thus can be sped up dramatically. And when empirical results are needed, new technologies permit feedback loops to be shortened and the process of "adaptive behavior" and learning through trial and error to be compressed. These advances improve policy implementation and allow for more real-time updating and refinement. ${ }^{163}$

\section{Quantification}

As environmental decisionmaking becomes more data-driven, several trends are likely to emerge. First, quantification expands the available menu of policy options. Most notably, quantitative data facilitates the "pricing" of pollution and natural resource consump-

160 See supra note 126 and accompanying text.

161 Jerome K. Vanclay, Realizing Opportunities in Forest Growth Modelling, 33 CANADIAN J. FOREST RES. 536 (2003), available at http://pubs.nrc-cnrc.gc.ca/cgi-bin/rp/ rp2_tocs_e?cjfr_cjfr3-03_33.

162 See De Alessi, supra note 152; see also Orbimage Global Imaging Info., SeaStar Pro Service: Find Fish Faster and Reduce Costs with Seastar Service From ORBIMAGE, at http://www.orbimage.com/seastar/seastar.html (last visited Feb. 25, 2004) (describing tool for tracking fish stocks).

163 A number of commentators have stressed learning as the key to a process of environmental progress through trial and error. See Daniel A. Farber, Eco-Pragmatism: Making Sensible Environmental Decisions in an Uncertain World 198 (1999) (arguing for creation of decisionmaking structures that "allow us to take advantage of increased knowledge over time"); KRIER \& URsIN, supra note 24, at 287-95 (discussing regulations as information-centered system of collective trial and error); James Salzman et al., Regulatory Traffic Jams, 2 Wyo. L. REv. 253, 286 (2002) ("Although much stock has been placed in both of the conventional models of regulatory compliance behavior, in truth, both rest at bottom on behavioral theories that postulate indicia of the respective behavioral trait and then rely for confirmation through the trial and error of policy responses."). 
tion, making market-based interventions more viable. If we know how much water a homeowner has used, it is much easier to impose usage fees. And if we can measure the level of emissions coming out of a car's exhaust pipe, charging for the harm becomes much easier.

Just as importantly, quantification changes the terms of the policy dialogue. Environmental decisionmaking increasingly can rely on actual on-the-ground results rather than expert opinion or, worse yet, rhetoric and emotion. ${ }^{164}$ Best guesses about optimal policy tools can be replaced with determinations based on measured results. Decisionmakers increasingly will be positioned to gauge environmental results not by "inputs" (e.g., how much money was spent to address a problem) but by "outputs" (e.g., how much improvement can be documented in ambient pollution levels). As the base of established fact expands, the zone of uncertainty-and thus political judgment and disputation-shrinks. ${ }^{165}$ This shift in the underpinnings for environmental decisionmaking may allow rationality and informed debate slowly to supplant ideological shrillness and partisan bickering. ${ }^{166}$ "Soft" data long has plagued the environmental realm and led critics to doubt whether policy choices were well-founded. In a data-rich environment, numerous opportunities exist to solidify the analytic foundations for policy.

Quantification also makes it easier to find environmental investments that are not paying off. In business, not every new product sells; in government, not every program works. Finding failing efforts is an important element of good management. A recognition that policies and programs must be evaluated regularly and rigorously-and resources redeployed where good results are not being achieved-has been long absent from the environmental domain. Quantitative per-

164 The problems with expert analysis have been well documented. See RoBYN N. Dawes, Ever yday Irrationality: How Pseudo-Scientists, Lunatics, and the Rest of Us Systematically Fail to Think Rationally 6-13 (2001) (demonstrating that decisions based on data and statistical prediction almost always outperform those based on expert judgment); Pildes \& Sunstein, supra note 53, at 48-55 (highlighting problems with expert analysis).

165 See The Urban Inst., Beyond Ideology, Politics, \& Guesswork: The Case For Evidence-BASEd Policy (2003) (arguing for data-based decisionmaking as way to get beyond "ideology, politics, and guesswork"); Daniel C. Esty, Toward Optimal Environmental Governance, 74 N.Y.U. L. Rev. 1495, 1519 (1999) (demonstrating how zone of uncertainty shrinks with additional data). But see Kabraman, supra note 158, at 25 (arguing that culture and values can suppress truth).

166 A shift toward a more quantitative and empirical approach to environmental protection might not be embraced by all. Environmentalists, in particular, have long been suspicious of quantitative, and especially cost-benefit, analysis. See e.g., Donald T. Hornstein, Reclaiming Environmental Laws: A Normative Critique of Comparative Risk Analysis, 92 Colum. L. REv. 562, 584-86 (1992) (discussing theoretical limitations of comparative risk analysis). 
formance measures promise to be an invaluable tool in changing the environmental policy culture in this regard.

As noted above, a more data-intensive approach to environmental decisionmaking facilitates analytic precision and refined standard-setting that respects differences across jurisdictions, issues, and individuals. The ability to handle diversity-of conditions, perceptions, and preferences-is one of the most critical factors required for improved environmental decisionmaking. ${ }^{167}$

Abundant data also makes it easier to find the best solutions within and among jurisdictions. Comparative analysis provides an important mechanism for improved environmental policy choices. The trend toward greater use of metrics and indicators is underway, with important gains already evident. ${ }^{168}$ Performance rankings make it easier to identify superior environmental strategies, policies, and technologies. Recent studies have shown that enormous progress can be achieved simply by moving laggards toward the "best practices" of those with top-ranked results. ${ }^{169}$

Data and information on what others are doing helps to define what is possible in the environmental arena. In many cases, governments, corporations, and households do not have a clear picture of what might be obtained in pollution control or resource management gains. Developing good environmental metrics thus helps to clarify appropriate targets or goals.

In the corporate context, environmental metrics allow executives to evaluate their pollution control and resource management practices with rigor. Facility-specific data can be used to identify top-tier performance, establish targets for progress, and provide a foundation for programs to move a corporation's operations toward leading-edge standards. Comparative statistics published by industry associations, international bodies, or the scientific community can generate additional benchmarks to guide environmental action.

167 See George A. Bermann, Taking Subsidiarity Seriously: Federalism in the European Community and the United States, 94 Colum. L. Rev. 331, 339-44 (1994) (arguing that diverse circumstances across jurisdictions requires customized law); Richard Briffault, Our Localism Part II-Localism and Legal Theory, 90 Colum. L. REv. 346 (1990) (explaining how legal theory must track divergent circumstances); Butler \& Macey, supra note 18, at 34-35, 43-44 (discussing need to address diversity in federal system); James E. Krier, The Irrational National Air Quality Standards: Macro-and Micro-Mistakes, 22 UCLA L. REV. 323, 326-30 (1974) (highlighting divergent circumstances that make uniform standards inappropriate).

168 See supra note 134 and accompanying text.

169 See Robert G. Eccles et al., The ValueReporting Revolution: Moving Beyond the Earnings Game 211-35 (2001) (providing examples of diffusion of best practices). 
Similar benchmarking opportunities may emerge at the household level. Electric bills in most places, for example, show not only how much energy was consumed in the prior month, but also provide a comparison with the last few months' electricity use or with the same month last year. But they do not provide the relevant comparison-showing how much a similar household of comparable size in the same geographic locale consumes. Such benchmarks could provide a real spur to action at the individual level with society-wide potential for reduced pollution, especially if combined with information on how the top performers have been able to reduce their use of electricity.

Additional benchmarking gains derive from the tendency of comparative analysis, particularly rankings, to spur competition. Evidence that others are outperforming one's country, community, or company on environmental criteria can heighten attention to opportunities for improved pollution control and better resource management. ${ }^{170}$ Competition not only motivates better performance; it often sparks innovation. ${ }^{171}$

\section{Transparency and Democracy}

Persuasive data and easy dissemination inevitably will increase "transparency" and undermine the governmental monopoly over decisionmaking. ${ }^{172}$ Even the governmental capacity to define the forum for political dialogue seems to be crumbling. Anyone with a website now can express a viewpoint and attack the prevailing wisdom. Data access gives "outsiders" and critics of those in power the means to challenge established policies as well as the assumptions and analyses on which they are based.

170 Daniel C. Esty, Why Measurement Matters, in Environmental Performance Measurement: The Global Report 2001-2002, at 6 (Daniel C. Esty \& Peter K. Cornelius eds., 2002).

171 Michael E. Porter, Competitive Advantage of Nations 586-87, 610-11 (1990) (explaining why competitive pressures generate innovation); Louis Lowenstein, Financial Transparency and Corporate Governance: You Manage What You Measure, 96 Colum. L. Rev. 1335, 1335-36 (1996) (explaining logic of disclosure rules); Ronald B. Mitchell, Sources of Transparency: Information Systems in International Regimes, 42 INT'L STUD. Q. 109, 110-13 (1998) (explaining logic and value of transparency); Cynthia A. Williams, The Securities and Exchange Commission and Corporate Social Transparency, 112 HARv. L. Rev. 1197, 1211-23 (1999) (explaining justification for disclosure emphasis in securities realm).

172 On the value of transparency, see Associated Press v. United States, 326 U.S. 1, 20 (1945) ("[T]he widest possible dissemination of information from diverse and antagonistic sources is essential to the welfare of the public ...."). See also Convention on Access to Information, Public Participation in Decision-making, and Access to Justice in Environmental Matters, June 25, 1998, 38 I.L.N. 517, available at www.unece.org/env/pp/documents/cep43e.pdf. 
Subpar regulatory results historically have been hard to spot, but when citizens (or environmental groups or the media) find out that other cities, states, or countries are delivering much better environmental results than their own government, they have a basis for complaint. For example, although Belgium has suffered from poor environmental conditions for decades, when the 2001 World Economic Forum Environmental Sustainability Index ranked the country seventy-ninth, just behind Albania, an uproar ensued in Brussels. ${ }^{173}$ Environmental groups, the media, and opposition politicians all pressed the government to explain the nation's relatively poor pollution control performance. ${ }^{174} \mathrm{~A}$ major rethinking of Belgium's environmental approach began.

The effects of increased transparency extend to the corporate realm. ${ }^{175}$ Companies now face scrutiny from "green" consumers, capital market analysts (some of whom see a correlation between environmental performance and financial results), ${ }^{176}$ corporate sustainability rating agencies, ${ }^{177}$ community activists, ${ }^{178}$ NGOs, ${ }^{179}$

173 Marc A. Levy, Measuring Nations' Environmental Sustainability, in ENvironmental Performance Measurement, supra note 170 , at 12, 19-20.

174 Political inquiries, press reports, and website "hits" are on file with the Center for International Earth Science Information Network at Columbia University (CEISIN), one of the groups involved in generating the Earth Science Information rankings.

175 See generally Don Tapscott \& David Ticoll, The Naked Corporation 3-36 (2003) (arguing that firms must accept world of transparency and improve their performance and governance).

176 See Glen Dowell et al., Do Corporate Global Environmental Standards Create or Destroy Market Value?, 46 MGMT. Sci. 1059, 1065-69 (2000) (finding positive market valuation associated with adoption of stringent environmental standards); Shameek Konar \& Mark A. Cohen, Does the Market Value Environmental Performance?, 83 Rev. Econ. \& STAT. 281 (2001) (finding that reduced emissions of toxic chemicals are correlated with higher market value); Michael V. Russo \& Paul A. Fouts, A Resource-Based Perspective on Corporate Environmental Performance and Profitability, 40 ACAD. MGMT. J. 534, 549 (1997) (reporting positive correlation between environmental performance and economic performance, especially in higher-growth industries).

177 See Frank Dixon, Financial Markets and Corporate Environmental Results, in ENVI. ronmental Performance Measurement, supra note 170, at 54 (providing overview of EcoValue'21 environmental performance ratings system); Alois Flatz, Corporate Sustainability and Financial Indices, in Environmental Performance Measurement, supra note 170 , at $66,66-80$ (discussing challenges of assessing sustainability and financial performance of leading companies).

178 See Hilary French, Vanishing Borders: Protecting the Planet in the Age of Globalization 10-12 (2000) ("New information and communications technologies are facilitating international networking, and activist groups, businesses, and international institutions are forging innovative partnerships."). These activists are also empowered by easy-access TRI data and other information such as the Environmental Defense "Scorecard." See Frances Irwin \& Carl Bruch, Information, Public Participation, and Justice, 32 EnvtL. L. REP. 10,784, 10,791-92, 10,795 (2002).

179 See generally P.J. Simmons, Learning to Live with NGOs, 112 ForeIGN POL'y 82 (1998) (discussing NGO activism); Timothy E. Wirth, Disinfectants, Nudes and Other 
industry associations, ${ }^{180}$ and environmentally conscious employees. Bad acts and poor results have become almost impossible to hide. Although it may be uncomfortable for some companies (as it has been for some governments), this new world of comparative data, instantaneous connections, open access, and transparency seems likely to intensify the focus on pollution problems and subpar natural resource management, speed up feedback loops, and increase the pace of environmental progress. ${ }^{181}$

In addition to increasing transparency, greater access to data and new mechanisms for "voice"-e-mail, websites, chat rooms, and blogs-democratize the environmental decisionmaking process. ${ }^{182}$ Simply put, more people can participate in the policy dialogue on any and every scale. Democratization does not just describe a new policy reality but has real normative value in the context of the uncertainties and information gaps of environmental policymaking. Connecting more people to cutting-edge thinking and engaging them in environmental debates means that a wider set of views, analyses, values, and policy options are considered. Cheaper and better data makes the intellectual marketplace undergirding the regulatory process operate

Adventures, 13 Colo. J. INT'L EnvtL. L. \& Pol'y 15 (2002) (exploring domestic and international impact of NGOs); The Non-Governmental Order: Will NGOs Democratize or Disrupt Global Governance?, Economist, Dec. 11, 1999, at 20 (discussing NGOs' increasing political power and use of Internet).

180 See Daniel J. Fiorino, Rethinking Environmental Regulation: Perspectives on Law and Governance, 23 HARV. ENVTL. L. REv. 441, 454-55 (1999) (noting that programs like Chemical Manufacturing Association Responsible Care "constitute efforts to improve the behavior of firms in different sectors and commit associations and their members to a more public responsibility for the environment"). For an overview of Responsible Care principles and requirements, see Responsible Care Practitioners Site, at http:// www.americanchemistry.com/rc.nsf/secondaryprofiles/lsgs-4nmdz?opendocument (last visited Feb. 23, 2004). See also Int'l Inst. for Env't \& Dev., Mining and Minerals Sustainability Survey 2001, at http://www.iied.org/mmsd/activities/industrysurvey.html (last visited Feb. 23, 2004); Nat'l Mining Ass'n, NMA Sustainable Development Principles, at http:// www.nma.org/policy/sustainable_dev.asp (last visited Feb. 23, 2004).

181 As management guru Don Tapscott likes to tell corporate leaders, "[I]f you're going to be naked, you'd better be buff." Face Value: Get Naked, ECONOMIST, Oct. 18, 2003, at 66 (detailing Tapscott's belief that greater business transparency is "an unstoppable force").

182 On the Internet's democratization potential, see generally Balkin, supra note 79 , at 19 ("[S]peech becomes democratized because technologies of distribution and transmission are put in the hands of an increasing number of people and increasing diverse segments of society throughout the planet."); Anupam Chandar, Whose Republic?, 69 U. CHI. L. Rev. 1479, 1481, 1493-95 (2002) (reviewing Cass Sunstein, Republic.com (2001)) (explaining democratizing power of Internet). 
more efficiently. ${ }^{183}$ Open decisionmaking also subjects environmental choices to ongoing review and critical comment.

Administrative law especially stands to be transformed by trends toward increased openness. In fact, a world of e-government is emerging. ${ }^{184}$ The Internet opens up regulatory proceedings, such as the notice-and-comment process required by the Administrative Procedure Act. Today anyone with a computer can track critical policy debates as they unfold in the public docket. Anyone with e-mail can register a comment, making distance from the physical locus of policymaking much less important. ${ }^{185}$ People with good ideas-even those who never get to Washington or their state capitals-thereby can have a chance to shape policy outcomes. ${ }^{186}$ This trend bodes well for the environment, as there is a growing scholarly literature that connects good environmental results with the strength of a jurisdiction's democratic institutions and the robustness of public debate. ${ }^{187}$

183 See Daniel C. Esty, NGOs at the World Trade Organization: Cooperation, Competition, or Exclusion, 1 J. INT'L ECON. L. 123, 135-37 (1998) (explaining value of competitive pressures in environmental policymaking process).

184 See, e.g., EPA Homepage, at http://www.epa.gov (last visited January 27, 2004) (providing full overview of EPA activities, including EPA Dockets, "online public docket and comment system designed to expand access to documents in EPA's major dockets"). For information on the Bush administration's broader e-government agenda, see egov: The Official Web Site of the President's e-government Initiatives, at http:// www.whitehouse.gov/omb/egov/ (last visited Feb. 23, 2004). See generally Barbara H. Brandon \& Robert D. Carlitz, Online Rulemaking and Other Tools for Strengthening our Civil Infrastructure, 54 ADMIN. L. REv. 1421 (2002) (explaining how Internet is fundamentally transforming administrative rulemaking); Irwin \& Bruch, supra note 178 (discussing impact of increased access to information on public participation).

185 Cary Coglianese, The Internet and Public Participation in Rulemaking 5-6 (Regulatory Policy Program, Center for Business and Government, John F. Kennedy School of Government, Harvard University, Working Paper RPP-2003-05, 2003), available at http://www.ksg.harvard.edu/cbg/research/rpp/RPP-2003-05.pdf.

186 Easy access could also result in "loud" interests having an easier time wielding influence. But the mechanisms for sifting inputs into the decisionmaking processes also may get better. In fact, significant efforts are being made by a number of software companies to produce programs that will sift and sort data and information. See, e.g., Press Release, Microsoft Corporation, Microsoft's Bill Gates Previews New "HailStorm" Technologies to Usher in New Era of More Consistent, Personalized and User-Centric Experiences (Mar. 19, 2001), available at http://www.microsoft.com/presspass/press/2001/mar01/ 03-19hailstormPR.asp; see also Rebecca Buckman, Microsoft Unveils Hailstorm Initiative, An Ambitious Web-Service Expansion, WALL ST. J. Eur., Mar. 21, 2001, at 26 (describing Microsoft web initiative providing wide array of networking opportunities for consumers).

187 See, e.g., Scott Barrett \& Kathryn Graddy, Freedom, Growth and the Environment, 5 ENV'T \& DEV. ECON. 433 (2000) (demonstrating impact of civil and political freedoms on environmental quality); Daniel C. Esty \& Michael E. Porter, Measuring National Environmental Performance and Its Determinants, in Global Competitiveness RePort 2000, at 60-75 (Michael Porter et al. eds., 2000) (showing empirical correlation between legal and political institutions and environmental results). 


\section{New Challenges and Old Problems}

Though there are many reasons to be optimistic about the contribution of Information Age technological advances to environmental protection, there are also reasons for caution. This new age could unfold in ways that make policymaking in general, and environmental decisionmaking in particular, more difficult. ${ }^{188}$

As data becomes more plentiful and less expensive, systematic efforts will be required to ensure that it gets translated into usable information and, ultimately, knowledge. ${ }^{189}$ As Enriquez notes, half of all the data ever collected in history has been obtained in the last four years. ${ }^{190}$ With more and more raw data and information being generated, environmental decision processes face the risk of information overload. In fact, the ability to sift information may soon become as important as the capacity to gather it. ${ }^{191}$

Environmental decisionmaking processes also will be vulnerable to concerted disinformation campaigns from both traditional special interests and perhaps new quarters. The Internet offers a cascade of crackpot theories, half-baked analyses, and unscientific data sets. Mechanisms to ensure accountability in cyberspace have not yet fully been developed. ${ }^{192}$ The free-wheeling spirit of the Internet commu-

188 Some even worry that the shift to a technology-based economy might in itself create new hazards or exacerbate existing pollution problems. These issues-including the need to dispose of heavy metals in computers, the unleashing of dangerous new substances, increased energy use, and a "rebound" effect from information-technology-induced economic growth-are beyond the scope of this Article, but have been addressed in detail elsewhere. See generally Bill McKibien, Enough: Staying Human in an EngiNEERED Age (2003); Bill Joy, Why the Future Doesn't Need Us, WIRED, April 2000, at 238 (highlighting new Information Age dangers); Joseph Romm, The Internet Economy and Global Warming 22-24 (1999), available at http://www.cool-companies.org/energy/ ecomm.doc (analyzing energy use of Information Age economy); Eric Williams \& Takaro Hatanaka, Sustainable Consumption and the Information Technology Revolution (United Nations University, Working Paper, 2003) (noting risk of environmental deterioration due to economic lift from information technologies), available at http://unit.aist.go.jp/lcacenter/lca/symposium/ws030319pfd/S1-5\%20Williams.pdf.

189 Douglas Aldrich has identified three requirements for the effective use of information: "[T]he ability to access it, the ability to assimilate and analyze it, and the ability to act on it." AlDRICH, supra note 143, at 31.

190 Juan Enriquez \& Rodrigo Martinez, The Smallest Ever Guide to Life SciENCES 22 (2003).

191 See supra note 189; see also Balkin, supra note 79, at 9 ("[T]he digital revolution makes salient what was always the case: the importance of organizing, sorting, filtering and limiting access to information.").

192 See generally Lessig, Future of IdEAs, supra note 120; WEB of DeCEPTION: MisINFORMATION ON THE INTERNET (Anne P. Mintz ed., 2002) (alerting readers to flood of deceptive, misleading, and erroneous information pervading the Web); see also Anne Wells Branscomb, Anonymity, Accountability, and Autonomy: Challenges to the First Amendment in Cyberspace, 104 YALE L.J. 1639, 1646-47 (1995) (discussing difficulties of regulating misuses and abuses of informational resources on Internet); Edward Lee, Rules and 
nity ${ }^{193}$ thus creates an added risk of dissemination of misinformation. ${ }^{194}$

More generally, giving "voice" to more people does not guarantee better policymaking. The promise of cyberdemocracy with a fully informed and engaged populace could give way to "spam," misinformation, and dialogue among the uninformed that diminishes thoughtful deliberation. ${ }^{195}$ More opinions being heard may lead to chaos and breakdown rather than higher quality decisions. ${ }^{196}$ Even if some participants in the policy process stay engaged, a flood of information could lead to narrowly focused decisionmaking with little consideration given to the broader context of a policy choice.

Some observers fear that the Information Age will narrow the flow of information that the average citizen sees, leading people to talk only to those who are like-minded, and reducing the level of political discourse and substantive debate. ${ }^{197}$ The extreme version of this fear can be seen in Sunstein's caricature of the "Internaut" who gets all of his information from a highly tailored set of websites producing a quotidian information sheet, which he mocks as the "Daily Me."198

Standards for Cyberspace, 77 Notre Dame L. Rev. 1275, 1317-21 (2002) (urging Congress to promulgate rules to ensure accountability in cyberspace); Beth Simone Noveck, Designing Deliberative Democracy in Cyberspace: The Role of the Cyber-Lawyer, 9 B.U. J. SCI. \& TECH. L. 1, 14 (2003) (detailing informational problems on Internet and challenges of enacting accountability and transparency regulations); Saul Hansell, Internet Is Losing Ground in Battle Against Spam, N.Y. Times, Apr. 22, 2003, at A1 (describing futility of technological and legal efforts to control unwanted solicitation over Internet); U.S. Seeks to End What it Calls Deceptive Email Operation, N.Y. TIMEs, Apr. 18, 2003, at C11 (chronicling recent government attempts to crack down on deceptive Internet practices).

193 See Lessig, Future of Ideas, supra note 120, at 9 (hailing freedom to "rip, mix, and burn").

194 See supra note 192 and accompanying text.

195 See Dennis Thompson, James Madison on Cyberdemocracy, in Democracy.Com: Governance in a Networked World 35, 40 (Elaine Ciulla Kamarck \& Joseph S. Nye, Jr. eds., 1999) (noting that "directness" may be advanced at expense of deliberation).

196 Joseph S. Nye, Jr., Technology.gov: Information Technology and Democratic Governance, in DEMOCRACY.COM, supra note 195, at 1, 8-14 (reviewing opportunities and challenges of Information Age democracy); see also supra notes 192-93 and accompanying text.

197 See William A. Galston, (How) Does the Internet Affect Community? Some Speculations in Search of Evidence, in Democracy.COM, supra note 195, at 45; see also Roza Tsagarousianou, Back to the Future of Democracy? New Technologies, Civic Networks and Direct Democracy in Greece, in Cyberdemocracy: Technology, Cities, and Civic Networks 41-59 (Roza Tsagarousianou et al. eds., 1998).

198 Cass R. Sunstein, Republic.com 3 (2001) (arguing that, with advent of television and Internet filtering technologies, one will "need not come across topics and views that [one has] not sought out. Without any difficulty, [one is] able to see exactly what [one] want[s] to see, no more and no less"). Sunstein later backed away from this position in response to a critique of Republic.com, claiming that it was only meant as a "thought experiment designed to cast light on the neglected requirements of a system of free expres- 
While the Internet enables knowledge about best practices to move quickly to places where it can be productively employed, this access often comes at the cost of intellectual property rights. Open access and a lack of respect for intellectual property could induce more innovation and faster dissemination of good ideas, ${ }^{199}$ but over time it might also result in reduced incentives for knowledge generation. ${ }^{200}$

Speedy dissemination also may exacerbate "network effects," locking in suboptimal standards and approaches. ${ }^{201}$ In the environmental area, the problem of existing technologies that have become de facto standards-deterring innovation-has long been understood. ${ }^{202}$ Governments can combat this tendency by ensuring that all environmental regulations take the form of performance standards (not technology mandates) and by quickly testing and certifying new methods of meeting requirements.

The presumption that more complete data and analysis yields better results will not always hold true. A "Rawlsian veil of ignorance" may promote policy progress and negotiated agreements in some circumstances:203 Climate change negotiators, for instance,

sion," and was in no way suggestive of "what most people are doing." Cass R. Sunstein, Response to James Fallow's "He's Got Mail", N.Y. Rev. OF Books, Apr. 25, 2002, at 61.

199 See Niall FitzGerald, Tomorrow's Wash: Challenges and Opportunities for the Detergents Industry in the 21st Century, Address Delivered by Chairman of Unilever PLC (Oct. 5, 1998) (casting doubt on whether environmental advances should "remain proprietary, thus limiting the potential benefits to society"), available at http://www.unilever.com/ news/speeches/2000/englishspeeches_967.asp (last visited Feb. 21, 2004).

200 Mitchell, supra note 8, at 63 (noting digital information technologies have caused collapse of traditional intellectual property approach to information). Nevertheless, the net impact may be neutral given the complex dynamics of information production in an open environment. See Lawrence Lessig, Copyright's First Amendment, 48 UCLA L. Rev. 1057,1072 (2001) (arguing for loose intellectual property rules in cyberspace). See generally Yochai Benkler, Coase's Penguin, or Linux and The Nature of the Firm, 112 Yale L.J. 369 (2003) (highlighting complexities of knowledge generation and intellectual property in cyberspace).

201 See generally Malcolm Gladwell, The Tipping Point: How Little Things Can Make a Big Difference (2000) (discussing "social epidemics" and their causes); Michael L. Katz \& Carl Shapiro, Systems Competition and Network Effects, 8 J. ECON. PersP. 93 (1994) (discussing network effects). It is important to note that the dynamic nature of the Information Age itself may overcome the risk of network effects and encourage continuous thinking about new directions for progress, but the uncertainty associated with technology argues in favor of the diligence described above. See Gladwell, supra, at 196-203; Katz \& Shapiro, supra, at 108.

202 See, e.g., Byron Swift, Barriers to Environmental Technology Innovation and Use, 28 ENVTL. L. ReP. 10,202 (1998) (describing significant and somewhat peculiar barriers to development and adoption of new environmental technologies, many of which stem from regulatory system itself).

203 See Geoffrey Brennan \& James M. Buchanan, The Reason of Rules: Constitutional Political Economy (1985), reprinted in 10 The Collected Works of JAMES M. BuCHANAN 35-36 (2000) (arguing that fundamental principles are best devel- 
might find it easier to agree on a strategy for reducing greenhouse gases if they do so in general terms before knowing the precise costs and benefits of emissions reductions in their own countries. ${ }^{204}$ Furthermore, transparent policymaking processes may be susceptible to manipulation by special interests unless administrative law and procedures evolve to control this threat. The Information Age also may empower only some segments of society and create a "digital divide" that leaves a disadvantaged subset out of the decisionmaking. ${ }^{205}$

Finally, it is possible that some data could actually be put to malevolent use. In the post-September 11 period, the EPA pulled a great deal of information on chemical sites and risks off its web page for fear that this material might facilitate the work of terrorists. ${ }^{206}$ Ultimately, as with any technological development, the potential for improved environmental policymaking in the Information Age will only be realized if the possible downsides to the new technologies are confronted and mitigated.

oped under veil of uncertainty); Oran R. Young, International Governance: ProTECTING THE ENVIRONMENT IN A STATEless SocieTy 101-03 (1994) (demonstrating how uncertainty can facilitate agreements).

204 See Kenneth J. Arrow et al., Intertemporal Equity, Discounting, and Economic Efficiency, in Climate Change 1995: Economic and Social Dimensions of Climate Change 125 (James P. Bruce et al. eds., 1996) (discussing impact of different approaches to determining appropriate discount rate for climate change analysis).

205 Much of the logic of this Article applies only in parts of the world where computers are common. See Irwin \& Bruch, supra note 178, at 10,793 (arguing that "[d]espite some notable efforts to cross the digital divide and to create a digital dividend, much of the United States' investment went into the technology bubble rather than into building a more sustainable world"). However, the World Resources Institute recently released a report finding that even developing countries are advancing policies that promote access to information. See Elena Petkova et al., World Res. Inst., Closing the Gap: Information, Participation, and Justice in Decisionmaking for the Environment 33-64 (2002), available at http://pubs.wri.org/pubs_pdf.cfm?PubID=3759 (last visited Feb. 21, 2004).

206 See Right to Know After September 11th: Hearing Before the Subcomm. on Water Res. and Env't of the House Comm. on Trans. and Infrastructure, 107th Cong. 14, 16 (2001) (testimony of Amy E. Smithson, Director, Chemical and Biological Nonproliferation Project, Henry L. Stimson Center) (explaining removal of sensitive data from EPA website to avoid providing terrorists with "a roadmap to the chemical calamities they could cause"), available at $\mathrm{http}: / /$ commdocs.house.gov/committees/Trans/hpw107-55.000/hpw107-55_0.htm (last visited Feb. 23, 2004). For an inventory of post-September 11 changes to federal government websites, see Gary Bass, A Post-September 11 Attack on the Right-to-Know, at http://www.ombwatch.org/article/articleview/212/1/1 (last visited Feb. 23, 2004). 


\section{IV \\ Institutional Redesign-From Markets TO Hierarchies}

The changed policymaking context outlined above will enable some important refinements to our existing structure of environmental institutions and may ameliorate some existing sources of market or regulatory failure. As Information Age technologies penetrate the environmental realm, the optimal mix of policy tools and institutions seems likely to evolve. The ability to fill information gaps changes the relative advantages and disadvantages of different regulatory regimes and effects a shift in our environmental protection "possibility frontier."

\section{A. Revitalizing the Environmental Property Rights Market}

Reliance on a property rights approach to environmental protection has been in decline for more than a century. As environmental problems became more complex, the resulting information demands led to widespread market failure. New digital technologies seem likely to reverse this trend by filling several types of information gaps that currently limit the utility of Coasean bargaining in the environmental context.

\section{Search Costs}

One of the most striking features of the Internet is its capacity to lower search costs and to bring together potential buyers and sellers who might otherwise not have found each other. ${ }^{207}$ In so doing, the Internet helps to "make markets" and to improve the efficiency of existing systems of exchange. ${ }^{208}$ This market-making capacity has several environmental applications. Most notably, "waste" more easily can be reused and recycled. Particular opportunities exist where one company's byproducts can serve as another's raw material. ${ }^{209}$ The chemical maker Rhone-Poulenc found, for instance, that the diacids

207 Cf. Herbert A. Simon, Administrative Behavior 79-109 (1976) (concluding that in any decision process, number of alternatives that must be explored and information required to do so is so great that individuals cannot achieve "any high degree of rationality"); Douglas C. North, Institutions, Transaction Costs and Economic Growth, 25 EcoN. INQUIRY 419 (1987).

208 See Kelly, supra note 120, at 185-94 (discussing attributes of "networked economy"); Alan Cohen \& John M. Jordan, Electronic Commerce: The Next Generation, Persp. on Bus. Innovation, Issue 3, 1999, at 7, 8-11.

209 See Marian R. Chertow, Industrial Symbiosis: Literature and Taxonomy, 25 ANN. REV. ENERGY \& ENV'T 313 (2000) (reviewing literature covering "industrial symbiosis"); Keith Pezzoli, Environmental Management Systems (EMSs) and Regulatory Innovation, 36 CAL. W. L. REv. 335, 363-64 \& n.87 (2000) (providing examples of industrial symbiosis). 
which are a byproduct of nylon production need not be incinerated but can be sold to tanneries for use as coagulants. ${ }^{210}$ Historically, the cost to the waste generator of finding such a synergistic partner often would have been prohibitively high, and the byproducts would have been discarded. Today, Internet-driven reuse/recycling relationships are multiplying rapidly. ${ }^{211}$

More plentiful and available information promises also to create better-informed consumers and thus to transform many existing product markets where environmental issues are a factor in the purchase decision. ${ }^{212}$ When the cost of getting information on the environmental dimensions of products is high, most purchasers ignore environmental factors. But as environmental data and analysis become more accessible, additional buyers will be positioned to factor environmental considerations into their choices. Eco-labels, Internet "environmental facts" websites, and other tools have created a wave of "green consumers" in markets from electric power to furniture to food. ${ }^{213}$

\section{Delineation of Environmental Rights}

Contractual exchange of environmental rights often seems untenable because those holding the rights are not in a position to bargain over their exchange. They lack sufficient information about the scope of their rights, whether an infringement has occurred, and what value to place on their rights. With improved technology, the victims of pollution will be better positioned to understand and defend their rights. While we may not be able to move to a pure market approach to protecting environmental rights anytime soon, improved problem visibility, harm traceability, analytic capacity, and transparency all seem likely to make Coasean bargaining viable in more circumstances.

The most visible improvement may come in physically delineating environmental rights. ${ }^{214}$ For example, Global Positioning Systems

210 Porter \& van der Linde, supra note 119 , at 125.

211 For a list of more than one hundred Internet bulletin board systems that are facilitating business-to-business "waste" transfers, see Recycler's World: The Recycler's Exchange, at http://www.recycle.net/recycle/exch (last visited Feb. 21, 2004); Waste Exchange Services Ltd.: Waste Exchange, at http:/www.wasteexchange.com/ Waste\%20Exchange.htm (last visited Feb. 21, 2004).

212 See supra note 35.

213 Already, a number of online entities are seeking to fill this environmental information market niche. See, e.g., Ecomall, at http://www.ecomall.com (last visited Jan. 14, 2004).

214 This potential has been recognized for some time. See, e.g., GARY D. LibeCAP, ConTRACTING FOR PROPERTY RIGHTS 17 (1989) ("New technology, which lowers the costs of delimiting individual claims, detecting rule violations, arbitrating disputes, and punishing violators, provides for further gains from applying a more specific assignment of property 
(GPS) and Geographic Information Systems (GIS) make the demarcation of property boundaries faster, easier, and cheaper. ${ }^{215}$ In combination with remote sensing, GPS and GIS technologies have the potential to improve the management of various open-access natural resources that are difficult to police. Historically, such resources have been vulnerable to overexploitation as each individual maximizes his or her own consumption at the expense of the community as a whole. ${ }^{216}$ "Tragedies of the commons," from overgrazing of cattle to overfishing of the ocean, long have vexed environmentalists. ${ }^{217}$ But just as barbed wire helped clarify property rights in the American West and facilitated more sustainable land use, information technologies can be deployed as "virtual barbed wire," permitting the fencing off of shares in common resources that previously might have been seen as ineluctably open for all. To return to the problem of fisheries management, quotas can be allocated and enforced using satellite tracking to observe and even measure the number of fish being taken by particular vessels. And while the prospect of keeping track of hundreds or even thousands of fishing boats might have seemed daunting a few years ago, today's computers can manage the task with relative ease. ${ }^{218}$ In fact, New Zealand's fisheries recently have been revived under a tradable quota regime reinforced by a sophisticated electronic tracking system. ${ }^{219}$ In light of such breakthroughs, our view of what constitutes an inherently collective resource may be dramatically altered.

Where resources are, by choice, managed as a public good (e.g., parks), the capacity to enforce limits on exploitation of the resource by individual actors will greatly be enhanced. From electronic signup

rights to reduce common pool losses."). In a similar vein, emissions-detecting technologies may be used to delineate and enforce "pollution rights." See Todd Hartman, Plan Aims to End Emissions Test: Remote Screening Would Target Polluters, But Clean Vehicles Would Get Pass in Mail, Denver Rocky Mountain News, Aug. 31, 2000, at A4.

215 See generally Scott D. Makar \& Michael R. Makar, Jr., Geographic Information Systems: Legal and Policy Implications, 69 FLA. B. J. 44 (1995).

216 See Garrett Hardin, The Tragedy of the Commons, 162 Scl. 1243, 1244-45 (1968) (explaining how common ownership of resources leads to overexploitation).

217 See, e.g., Frederick W. Bell, Technological Externalities and Common-Property Resources: An Empirical Study of the U.S. Northern Lobster Fishery, 80 J. PoL. ECoN. 148 (1972) (documenting overexploitation of fishery).

218 Satellite tracking of fishing fleets is now both well-developed and cheap enough that it is marketed directly to private corporations in the marine industry for individual fleet communication and observation. See SASCO, Economical Satellite Communications and Tracking for the Marine Industry, at http://www.sasco-inc.com/default.htm (last visited Jan. $14,2004)$. Satellite tracking is also being incorporated into environmental regulation in Britain. See Sea Fishing (Enforcement of Community Satellite Monitoring Measures) (Wales) Order 2000, (2000) SI 2000/1078.

219 See De Alessi, supra note 152. 
sheets for tent sites in Yellowstone National Park to the tracking of greenhouse gas emissions released into the earth's atmosphere, ${ }^{220}$ the costs of defining, protecting, and trading environmental property rights appear likely to drop precipitously in the coming decades.

Finally, information advances may ease the strain that often exists where ecological resources are divided between private property owners and public entities. Computer-aided mapping and data storage in high-resolution GIS makes the presence of endangered species or protected wetlands on private lands much easier to track and predict. The capacity to foresee a problem also reduces the chances that those buying land will face a use-restricting "surprise" that raises a takings issue. ${ }^{221}$ Simultaneously, the extent of "positive externalities" generated by private landowners will be much easier to gauge, facilitating compensation or credit for those whose careful private land management practices generate public benefits. ${ }^{222}$

\section{Valuation and Strategic Behavior}

Even if we know with a reasonable degree of precision the sources and impacts of emissions and who holds the relevant property rights, a market-based approach to environmental protection remains untenable unless those engaged in exchanges know how much value to place on the various resources or harms in question. Important dimensions of the "valuation" problem soon may be overcome through greater emphasis on data-driven decisionmaking, which facilitates better risk assessments and more sophisticated cost-benefit analysis..$^{223}$

Of course, a more quantitative approach to environmental protection will not eliminate all information gaps and concomitant decisionmaking breakdowns, bargaining failures, and strategic behavior.

220 See Jonathan Baert Wiener, Global Environmental Regulation: Instrument Choice in Legal Context, 108 YALE L.J. 677, 709-13, 763-68 (1999) (arguing that allocation of atmospheric property rights may become possible).

221 To the extent that the Supreme Court's jurisprudence in this area turns on "reasonable investment-backed expectations," see Lucas v. S.C. Coastal Council, 505 U.S. 1003, 1019 n.8, 1027 (1992), increased information should reduce the number of Endangered Species Act takings cases and wetlands disputes to near-zero.

222 See Carol M. Rose, Property Rights and Responsibilities, in Thinking EcologiCALLY, supra note 31 , at 49,57-58 (arguing that private property owners should be compensated for public benefits they provide).

223 See Robert W. Hahn, Reviving Regulatory Reform: A Global Perspective 6-31 (2000) (discussing possible improvements in cost-benefit analysis); James K. Hammitt, Data, Risk, and Science: Foundations for Analysis, in Thinking Ecologically, supra note 31, at 150,152-57 (describing refined tools for cost-benefit analysis); see also generally CASS R. SunSTEIN, RISK AND REASON: SAFETY, LAW, AND THE ENVIRONMENT (2002) (suggesting that risk regulation should be based on cost-benefit analysis). 
But better data, in combination with a more transparent policymaking process, will make anomalous value claims stand out more sharply. In trying to place a value on a child's pollution-induced asthma, for example, the amounts paid in compensation in other similar cases will be easily accessible. Thus, a rights holder who tries to overplay his hand and advance an indefensibly large claim will be stymied.

Value judgments will, of course, still have to be made. ${ }^{224}$ The price to be placed on particular kinds of harms, such as loss of a life, an increased risk of cancer, or a diminished view are not obvious. These questions are not so much technical as they are philosophical and political.225 Even so, a more information-rich decisionmaking process can reduce the scope for dispute and ameliorate the institutional challenges posed.

\section{Decollectivization}

In some cases, information technologies offer the prospect of promoting individual environmental decisionmaking in the marketplace instead of "policymaking" with its susceptibility to error, inefficiency, and special interest capture. Such a shift makes sense where risks and impacts can be internalized at the individual or household level. Decollectivization is particularly useful where tastes and values vary and where individuals are capable of making informed choices in a market context. ${ }^{226}$ Under such an approach, individuals decide for themselves how to weigh the competing risk and cost factors and can thus determine what to buy. The regulatory role can be limited to providing reliable information.

Food safety stands out as an area where some choices that are presently made in a regulatory setting can be devolved to the individual and the market. The decision, for instance, whether to buy food derived from genetically modified organisms (GMOs) or to purchase GMO-free products may be better left to individuals rather than regulators. ${ }^{227}$ Where individual choice represents the preferred environmental protection strategy, eco-labels or other information-

224 See Howard Latin, Good Science, Bad Regulation, and Toxic Risk Assessment, 5 YALE J. ON REG. 89 (1988) (dismissing feasibility of purely scientific or rational environmental decision making).

225 See Mark Sagoff, We Have Met the Enemy and He Is Us or Conflict and Contradiction in Environmental Law, 12 ENVTL. L. 283, 286-97 (1982) (arguing that valuations inevitably turn on value judgments).

226 See William A. Galston, Liberal Pluralism 5-6, 32-33 (2002) (defending pluralism and recognition that some value conflicts cannot be reconciled).

227 See John Charles Kunich, Mother Frankenstein, Doctor Nature, and the Environmental Law of Genetic Engineering, 74 S. CAL. L. REv. 807, 859-72 (2001) (explaining why regulation of genetically modified organisms should have information focus). 
provision strategies make sense as a way to promote informed consumer preferences.

\section{Contracting Beyond Small Numbers}

The likelihood of negotiating efficient environmental outcomeswhere harm-causers compensate those whose rights have been infringed or where pollutees pay polluters to reduce the harms-long has been understood to diminish beyond the realm of small numbers. 228 But the Internet and the growing network of other Information Age mechanisms for linking people together may change what counts as "small." 229 Dispersed individuals with a common purpose may find it easier to achieve collective action. ${ }^{230}$ More specifically, environmental rightsholders may be able to organize themselves at much lower cost than in the past, enabling them (or their agents) to negotiate more systematically and effectively. ${ }^{231}$

One can imagine, for example, that property developers seeking to site a new factory may be able to negotiate electronically with the neighbors over compensation for any associated noise or dust. Individualized payments might be determined by modeling an array of factors such as distance from the site, direction of the prevailing wind, and susceptibility to harm. The greater the experience base and the more data we have to build such analysis, the more likely we are to be able to generate a proposal that meets the expectations of both harm causers and victims.

There are, however, real limits to how much environmental information individuals can process and thus how far Coasean bargaining can go as the centerpiece of our environmental regime. ${ }^{232}$ Some dimensions of environmental problemsolving are inescapably complex. The presence of good data and analysis does not therefore guarantee good decisions.

228 See Coase, supra note 1 (discussing parameters for successful bargaining).

229 One of the greatest values of the Internet is its capacity to "connect people in a relevant and timely fashion." John Hagel III \& Marc Singer, Net Worth: Shaping Markets When Customers Make the Rules xii (1999).

230 See Howard Rheingold, Smart Mobs: The Next Social Revolution (2002) (explaining how Internet facilitates collective action).

231 See e.g., Paul M. Schwartz, Privacy and Democracy in Cyberspace, 52 V And. L. Rev. 1609, 1648-50 (1999) ("Cyberspace has the potential to emerge as an essential focal point for communal activities and political participation."); see also Jocelyn C. Adkins, The Internet: A Critical Technology for the State of Environmental Law, 8 VILL. ENVTL. L.J. 341 (1997) (describing how Internet makes retrieval and dissemination of critical environmental information more efficient on global scale).

232 See Jolls et al., supra note 73 (discussing difficulties individuals have in making accurate risk assessments). 
Individuals also rationally may choose to limit the number of environmental choices they make. Even as the cost of becoming informed falls dramatically, extensive individual environmental decisionmaking still may be onerous for many citizens. Simply put, how many individuals would want to negotiate compensation agreements with the polluting factories in town? Or even find an agent to do so?

The combination of human cognitive limitations, an environmental problem set that is technically complex, and a rational choice on the part of many citizens to limit the time they spend on environmental matters circumscribes the ultimate scope of pollution control and natural resource management based on a property rights model. Thus, while we can anticipate a more robust environmental marketplace in the future, a pure market approach to environmental protection seems unlikely anytime soon.

\section{B. Court Protected Entitlements}

Insofar as the shift toward regulation arose, in part, because of frustration with the inability of courts to overcome information gaps in environmental cases, ${ }^{233}$ better analytic underpinnings for courtbased decisionmaking may reverse the trend. It is likely that the data gains and decisionmaking advances outlined above will narrow the scope of environmental information gaps in ways that facilitate judicial decisionmaking.

To the extent that courts have been troubled by causation and valuation issues, advances that make harms more visible, easier to understand and evaluate, and more amenable to pricing will ease the burden on the judicial system. The presence of vast stores of comparative data also makes it easier to spot outlier damage claims, bring pressure to bear on holdouts, and discipline strategic behavior, facilitating adjudication of contract disputes.

233 In a series of nineteenth century pollution cases both in Britain and in the United States, courts failed to stop harms emanating from industrial facilities, finding that data to justify intervention had not been brought forward. See, e.g., Francis v. Schoellkopf, 53 N.Y. 152 (1873); Sparhawk v. Union Passenger Ry. Co., 54 Pa. 401 (1867); St. Helen's Smelting Co. v. Tipping, 11 Eng. Rep. 1483 (1865); Hole v. Barlow, 140 Eng. Rep. 1113 (1858). In Huckenstein's Appeal, for example, the Pennsylvania Supreme Court rejected a special master's conclusion that sulfuric fumes from the defendants' brickyard caused plaintiff's harms, suggesting that a sufficient causal link had not been established. $70 \mathrm{~Pa}$. 102,107 (1871). The broader case history of this period is replete with decisions turning on problems of harm identification, causation, valuation, and other elements of the information gap taxonomy developed above. For a complete discussion, see Joel Franklin Brenner, Nuisance Law and the Industrial Revolution, 3 J. LEgAL STud. 403 (1974). See also Rosen, supra note 110. 
These gap-filling gains are important because a well-functioning tort system is a necessary backstop for a property-rights-based environmental regime. Thus, many of the advances enumerated in the preceding Section, which make markets function more smoothly and negotiations easier to conduct, also facilitate court-based decisionmaking. Improved judicial capacity to adjudicate environmental disputes simultaneously makes it possible to envision an expanded domain for environmental property rights and their exchange.

\section{Command-and-Control Regulation}

Improved information will not mean perfect information. But even where command-and-control regulation persists, enhanced environmental information promises to mitigate various sources of regulatory failure including: (1) technical deficiencies; (2) cognitive shortcomings; (3) structural (or jurisdictional) mismatches; (4) public choice failures; and (5) administrative inefficiencies.

\section{Technical Deficiencies}

Most fundamentally, information technologies will enable regulators to sharpen their evaluation techniques, deal with diversity, and manage complexity. Thus, to the extent that incomplete or inaccurate information leads to regulatory mistakes, the number and magnitude of these errors seem likely to diminish. Moreover, regulatory shortcuts taken to reduce administrative costs will become less necessary. As noted earlier, as the cost of precision falls, reliance on grossaverage data can be cut back. ${ }^{234}$ Uniform standards can be replaced with a more individualized regulatory regime that is tailored to particular circumstances.

Access to the requisite scientific, technical, and analytic underpinnings for sound regulation will make decentralization-and its recognized advantage of moving decisionmaking closer to the people and the problems involved-more viable. ${ }^{235}$ State and local regulators, and regulators in less developed countries, will be better positioned to manage the challenges they face in a sophisticated manner. Online training and Internet access to "help desks" staffed by technical experts could further diminish capacity problems and strengthen the claim for devolution of environmental responsibilities to decentralized officials who can fine-tune interventions to meet local conditions.

234 See text accompanying supra notes 122-25.

235 See Butler \& Macey, supra note 18 (arguing for reallocation of regulatory authority to states); see also James E. Krier, On the Topology of Uniform Environmental Standards in a Federal System-and Why It Matters, 54 MD. L. Rev. 1226, 1228-35 (1995) (explaining advantages and disadvantages of decentralized decisionmaking). 


\section{Cognitive Shortcomings}

In a number of areas, environmental progress has been stymied by the limits of the human mind to process risk information, take unseen problems seriously, understand points of environmental leverage, and agree on appropriate actions in response. ${ }^{236}$ Perception problems can be difficult to overcome, but they may be mitigated through quantification and more sophisticated information displays. ${ }^{237}$ Public understanding of drinking water problems, for example, has been enhanced greatly by mandatory "consumer confidence reports" which spell out the maximum contaminant levels (MCLs) in a water supply and how these results compare with the EPA-established maximum contaminant level goals (MCLGs). ${ }^{238}$

A more empirical and data-driven approach to environmental protection also offers a promising avenue for overcoming the exaggerated emphasis given to sensational or emotion-laden problems and mitigating the effects of "availability cascades" triggered by the media or those with special interests to advance. ${ }^{239}$ To the extent that Information Age technologies help to sharpen our understanding of problems, provide context for decisionmaking, and provide empirical foundations for policy choices, they will ease the human tendency to focus on the "here and now," reduce the impact of the availability heuristic, and mitigate other cognitive failures.

\section{Structural or Jurisdictional Mismatches}

The potential for more refined governance at a variety of levels should help to reduce welfare losses from structural failures where governmental regulation is undertaken at the wrong scale or jurisdiction. The ability, more specifically, to identify environmental problems makes it easier to match the scope of regulating jurisdictions to the scope of environmental problems. ${ }^{240}$ We know that environ-

236 See supra note 19.

237 See TUFTE, supra note 155; supra notes 156-59 and accompanying text (discussing ozone depletion). But see Kahan \& Braman, supra note 60 (arguing that more statistics will not penetrate if people are culturally distrustful of "factual" sources).

238 Safe Drinking Water Act Amendments of 1996, Pub. L. No. 104-182, 110 Stat. 1613, 1639 (1996) ("[E]ach community water system . . . [is required to] mail to each customer of the system at least once annually a report on the level of contaminants in the drinking water purveyed by that system.").

239 See, e.g., Ian Ayres \& John J. Donohue III, Shooting Down the "More Guns, Less Crime" Hypothesis, 55 STAN. L. Rev. 1193, 1296 (2003) ("Over time, a body of empirical research can disentangle thorny issues at causation and lead toward consensus.").

240 See Mancur Olson, Jr., The Principle of "Fiscal Equivalence": The Division of Responsibilities Among Different Levels of Government, 59 Am. ECON. Rev. 479, 482-84 (1969) (arguing that scope of public goods should match scale of jurisdiction making deci- 
mental problems exist on multiple geographic scales. ${ }^{241}$ To the extent that the "matching principle" 242 - a core element of optimal environmental governance and its underlying public goods theory-argues for regulatory intervention at the same scale as the problem, we face the prospect of a nearly infinite number of "optimal environmental areas." 243 While the administrative costs of having regulating authorities available at every such scale would be exorbitant, the relative burden of a multi-tier environmental governance structure goes down as information costs fall, making more affordable a structure that better matches the scale of problems.

Likewise, the greater ease with which policy complexity can be managed in the Information Age makes environmental federalism, with responsibilities shared across levels of government, more feasible. Under such an approach, the federal government can be charged with undertaking those aspects of policymaking (e.g., problem identification, dose-response evaluations) where economies of scale are salient or the logic of centralization is strong. City or state officials can take on those elements of the regulatory process (e.g., evaluating intervention options and costs in light of local circumstances) that benefit from localized information.

\section{Public Choice Distortions}

Environmental progress ultimately depends as much on institutional reforms as it does on technological advances. The capacity for more refined internalization of externalities must be matched with the political will to do so. But the technological advances of the Information Age may help to mitigate existing decisionmaking pathologiesmost notably, public choice distortions - clearing the way for institutional reform.

sions); see also Butler \& Macey, supra note 18, at 25 (explaining "matching principle," which suggests regulation be undertaken at scale of harm).

241 See President's Council on Sustainable Dev., Sustainable America: A New Consensus for Prosperity, Opportunity, and a Healthy Environment for the Future vi, 11-23, 83-107 (1996) (discussing need to address environmental problems at community, national, and international levels), available at http://clinton4.nara.gov/PCSD/ Publications/TF_Reports/amer-top.html. A related discussion of geographic scales is found in J.B. Ruhl, Sustainable Development: A Five-Dimensional Algorithm for Environmental Law, 18 STAN. ENvTL. L.J. 31, 41-42 (1999).

242 Mancur Olson, The Logic of Collective Action: Public Goods and the THEORY OF GROUPs (1971) (discussing jurisdictional scale and provision of public goods); Butler \& Macey, supra note 18, at 25; Olson, supra note 240, at 482-84 (observing that "internalities" arise when public good reaches only subset of population in jurisdiction).

243 See André Dua \& Daniel C. Esty, Sustaining the Asia Pacific Miracle: Environmental Protection and Economic Integration 123-31 (1997) (developing concept of "optimal environmental areas"). 
In an opaque and data-poor policy environment, judgments corrupted by special-interest influence may go unchallenged for long periods. $^{244}$ In a more transparent world, however, rent-seeking behavior stands out more distinctly. An information-rich environmental regime cannot put a stop to special-interest manipulation of the policymaking process, but it can expose poor choices and weak results, thereby helping to reinforce pressures for better performance. ${ }^{245}$ Furthermore, where data is plentiful and comparisons are easy to make, outcomes that deviate from established best practices are more likely to be visible.

More generally, environmental politics has been marked by a particular asymmetry whereby narrow, well-organized interestsoften industrial producers or natural resource extractors-distort policymaking at the expense of a diffuse and politically unorganized public. ${ }^{246}$ Special interests thrive on chaos, confusion, and weak analytic footings in the policy process. The wider the array of information gaps to be filled, the greater the opportunity to mold outcomes. Closing the information gaps therefore will reduce the opportunities for special-interest manipulation and clear space for an appropriate public policy dialogue.

Easy access to information on who is participating in the decisionmaking process provides an additional tool for controlling specialinterest influence. 247 Mandatory lobbying disclosure reports, for instance, make it much easier to throw a spotlight on instances of regulatory "capture," where disproportionate influence is being wielded by certain groups or individuals. ${ }^{248}$ Similarly, in jurisdictions where

244 See Ross Gelbspan, The Heat Is On: The Climate Crisis, the Cover-up, the Prescription 33-61 (2d ed. 1998) (describing fossil fuel industry's financing of climate science contrarians to cloud policy picture).

245 Daniel C. Esty, Toward Data-Driven Environmentalism: The Environmental Sustainability Index, 31 ENVTL. L. REP. 10,603, 10,606-09 (2001) (discussing how data illuminate problems); Esty, supra note 170, at 4-6 (highlighting nature of comparative data).

246 See William N. Eskridge, Jr., Politics Without Romance: Implications of Public Choice Theory for Statutory Interpretation, 74 VA. L. REv. 275, 285-89 (1988) (highlighting capacity of special interests to subvert policy process). But see Daniel A. Farber, Politics and Procedure in Environmental Law, 8 J.L. ECON. \& ORG. 59, 78-79 (1992) (observing that environmental legislation defies traditional interest-group theories, conferring broad public benefits in face of organized special interests).

247 The Common Cause website, for example, allows users to search a database of special interest soft money contributions to the major political parties. See The Soft Money Laundromat, at http://www.commoncause.org/laundromat (last visited Feb. 23, 2004). For a comprehensive picture of campaign contributions and lobbying spending, see OpenSecrets: Your Guide to the Money in U.S. Elections, at http://www.opensecrets.org (last visited Feb. 23, 2004) (providing information on donors to political candidates).

248 Senate lobbying disclosure reports are available at the U.S. Senate Office of Public Records website, at http://sopr.senate.gov (last visited Feb. 23, 2003). 
lavish campaign contributions or even outright corruption taint decisionmaking, Information Age tools (e.g., online access to campaign finance reports or officeholder financial disclosure statements) can unveil such influence, making improper behavior much harder to sustain. ${ }^{249}$

More dramatically, the shift towards an environmental regime where corrective justice is taken more seriously and victims are compensated for the harms they suffer could fundamentally transform environmental politics. Specifically, the potential for compensation changes the payoff matrix for political engagement and collective action among the diffuse set of pollutees. With real money at stake, political entrepreneurs might be motivated to organize pollution victims and to act as their agents in negotiating better programs of pollution control, more complete cost internalization, and full compensation.

\section{Administrative Inefficiency}

To the extent that inefficiency can be traced to incapacity, the powerful dissemination tools of the Information Age will make it possible for regulators more easily to identify and adopt successful policies, technologies, and regulatory approaches from across the country and around the world. Ignorance of the presence of better approaches increasingly will be unavailable as an excuse.

New disciplines on bureaucratic behavior are likely to yield more efficient regulation. The general trend toward transparency and easily available benchmarks on environmental results facilitates government-to-government performance comparisons. ${ }^{250}$ As discussed above, rankings and comparisons intensify "regulatory competition" and may help to reduce bureaucratic self-dealing or inefficiency.

Wider flows of information increase the number of competitors in the intellectual marketplace and intensify regulatory competition on a number of fronts. The pressure on governments for better environmental performance increasingly will come not just from a Tieboutian "horizontal" interaction (e.g., California's innovations being copied by Oregon, cutting-edge U.S. strategies being emulated by the European

249 Federal campaign disclosure reports can be found at The Federal Elections Commission: Campaign Finance Reports and Data, at http://www.fec.gov/finance_reports.html (last visited Feb. 23, 2003). For another approach to the same set of issues, see OpenSecrets: Your Guide to the Money in U.S. Elections, at http://www.opensecrets.org (last visited Feb. 23, 2004).

250 See supra notes 172-74 and accompanying text. Initial efforts to rank governments based on their environmental performance have begun to emerge. See WorLd Econ. ForUm, supra note 134, at 3 tbl.1; Esty \& Porter, supra note 187, at 31-36 (using regression analysis to identify determinants of environmental policy success). 
Union), but also from "vertical" competition (and cooperation) between levels of government. ${ }^{251}$ With easier access to comparative data, policy successes at the state level (or international level) can stimulate "copycat" federal legislation or regulations. ${ }^{252}$ Likewise, superior regulatory performance at a local or federal scale will keep state environmental decisionmakers on their toes.

The same principles of "co-opetition," 253 fostered by greater access to information and broadened capacity for leading-edge analytic work, will create the potential for a welfare-enhancing mix of competition and cooperation between governments and non-governmental organizations, including environmental groups and the business community. ${ }^{254}$ Although there is some risk of cacophony or information overload, input from alternative perspectives generally facilitates problemsolving in the environmental realm. ${ }^{255}$

\section{Market-Based Regulation}

Economic-incentive-based regulation represents a waypoint between the information intensity required for a fully functioning property rights regime and the broad-scale collectivized decisionmaking of command-and-control regulation. The same breakthroughs in information technology that may eventually facilitate a vibrant market in environmental rights promise more immediate gains through the expanded use of market-based regulatory tools.

To the extent that information technologies ameliorate valuation disputes, make property rights easier to define and defend, and generally lower transaction costs, they eliminate a number of the obstacles that have prevented broader adoption of market-based regulatory

251 For a review of "horizontal" regulatory competition theory, see generally Richard Revesz, Federalism and Regulation: Some Generalizations, in REGULATORY COMPETITION AND ECONOMIC INTEGRATION, supra note 21, at 3; Charles M. Tiebout, $A$ Pure Theory of Local Expenditures, 64 J. Pol. EcoN. 416 (1956) (proposing model for calculating "the level of expenditures for local public goods which reflects the preferences of the population more adequately than they can be reflected at a national level"). Esty and Geradin argue for an expanded conception of horizontal competition and a focus on vertical competition. Daniel C. Esty \& Damien Geradin, Regulatory Co-opetition, in Regulatory COMPETITION AND ECONOMIC INTEGRATION, supra note 21, at 30 (discussing value of both competition and cooperation).

252 The 2002 adoption in California of a law mandating reduced greenhouse gas emissions from vehicles, in the face of federal government inaction on climate change, provides a vivid example of this dynamic. See Cal. Health \& Safety Code $\$ 43018.5$ (West 2003).

253 Esty \& Geradin, supra note 251, at 30.

254 Id. at 38-46 (explaining virtues of inter-, intra-, and extra-governmental co-opetition on both horizontal and vertical axes).

255 See supra Part IV.B. 
strategies. ${ }^{256}$ Market-based regulation, moreover, tends to draw out decentralized data and information that would otherwise not be available to decisionmakers. ${ }^{257}$

An improved capacity to measure emissions and trace harms is especially important to the internalization of externalities using pricing mechanisms. In the last decade, market forces have been harnessed to promote environmental objectives through the use of both Pigouvian pollution fees and emissions allowance trading schemes in such critical areas as CFCs and acid rain control.258 Wetlands "banking" is made much easier, for example, with sophisticated databases that track, price, and make available for purchase various wetlands restoration and creation projects so that developers can more easily and precisely offset the damage they cause. ${ }^{259}$

Emissions allowance trading regimes traditionally have been seen as vulnerable to the possibility that either the wrong number of permits to achieve the desired level of control would be issued or that the price of the permits would fluctuate wildly. ${ }^{260}$ Information technologies can be used to generate valuable supply and demand information, speed up feedback loops, and thus facilitate quicker "clearing" of

256 See Nathaniel O. Keohane et al., The Choice of Regulatory Instruments in Environmental Policy, in Economics of the Environment: Selected Readings 559, 594-98 (Robert N. Stavins ed., 2000) (describing how limits on information available to voters create incentives for politicians to choose command-and-control, rather than marketbased, strategies).

257 Under a traditional command-and-control regulatory model, the government must develop an in-depth understanding of the regulated industry so as to determine the right level of pollution control and the best approach to abatement mandates. In contrast, under a market-based approach, the companies themselves-armed with site-specific information on emissions, alternative production possibilities, and abatement options-make the critical decisions about how to meet the regulatory requirements. This process requires information production-and sometimes information sharing. See ScHucK, supra note 13, at 439 ("Whereas law must rely on centralized political institutions to gather, process, interpret, disseminate and correct information, markets radically decentralize it to individuals and firms.").

258 See 42 U.S.C. $\$ 7651$ b(b) (2000) (authorizing acid rain allowance trading); J. Andrew Hoerner, Taxing Pollution, in Ozone Protection in the United States: Elements of SuCCEss 39, 44-47 (Elizabeth Cook ed., 1996) (discussing contribution of Ozone-Depleting Chemicals Tax to reduction in consumption of ozone-depleting chemicals).

259 Envtl. LaW Inst., Wetland Mrtigation Banking (1993) (explaining how mitigation banking works); Royal C. Gardner, Federal Wetland Mitigation Guidance: Missed Opportunities, 26 ENVTL. L. REP. 10,075 (1996) (highlighting critical issues in wetlands banking). But see James Salzman \& J.B. Ruhl, Currencies and the Commodification of Environmental Law, 53 STAN. L. REv. 607, 648-61 (2000) (noting factors that limit value of banking and trading).

260 See B.S. Fisher et al., An Economic Assessment of Policy Instruments for Combating Climate Change, in Climate Change 1995, supra note 204, at 397 (discussing possibility of implementing tradable-permit system in combination with international carbon tax, and potential for under-or over-abatement). 
emissions markets. Similarly, when environmental taxes are employed as a pollution control measure, there is no guarantee that they will be set at the right level to achieve the desired degree of emissions control. Again, recently developed information and communications technologies provide a capacity to monitor market behavior on a real-time basis, including behavioral changes induced by economic incentives. ${ }^{261}$ By tracking activity patterns, regulators will be able to adjust tax rates to achieve optimal emissions levels.

Although political obstacles undoubtedly stand in the way, we are not very far away, as a technical matter, from being able to measure and thus establish a marginal cost for all emissions harms. ${ }^{262}$ This capacity creates an opportunity to shift our regime of environmental protection dramatically toward market-based institutions. The leading edge of this trend can already be seen in places like Singapore, where commuters pay electronically-deducted tolls with differential charges, depending on how far into the urban center they take their cars and at what time of day. ${ }^{263}$ Complicated, multivariable fees might confuse the paying public, but the chance to tailor incentives with considerable precision nonetheless represents a major policy opportunity.

\section{E. Social Context}

The fact that community norms can shape environmental behavior even in the absence of legal structures is well established. ${ }^{264}$ The environmental movement of the past thirty years has done a great

261 See, for example, the work of Richard Sandor and his company, Environmental Financial Products, at http://www.chicagoclimatex.com (last visited Feb. 23, 2003) (creating carbon emissions reduction market).

262 See, e.g., M. A. Gondal, Laser Photoacoustic Spectrometer for Remote Monitoring of Atmospheric Pollutants, 36 ApPLIEd Optics 3195, 3195-96, 3200-01 (May 20, 1997) (describing technology that will simplify monitoring of air pollutants); see also Ion-Optics website, at http://www.ion-optics.com (last visited Feb. 23, 2003) (highlighting emerging laser-beam-based technologies).

263 John T. Berg \& Felicia B. Young, Value Pricing Helps Reduce Congestion, PuB. ROADS, March/April 1999, at 47, 50. The Singapore experience suggests that pollution charges can be set to reflect not only the precise amount of pollution coming out of the tailpipe of a particular vehicle, but also varied according to the time of day as well as the geographic locale in which one is driving-both factors which affect the level of harm inflicted and thus the appropriate charge under an economically-optimal marginal cost pricing scheme. London has recently adopted a similar vehicle pricing regime for the center city. See Randy Kennedy, The Day the Traffic Disappeared, N.Y. Times MaG., Apr. 20,2003 , at 42-43.

264 Robert Ellickson has chronicled a number of circumstances where externalities are internalized on the basis of community norms rather than formal legal mandates. See Ellickson, supra note 94, at 184-206; Robert C. Ellickson, Law and Economics Discovers Social Norms, 27 J. LegAL STUD. 537, 540 (1998) ("Informal systems of external social control are far more important than law in many contexts . . ."); see also FLORINI, supra note 34 (discussing how transparency and disclosure strengthen norms); Eric Talley, Dis- 
deal to change the social context within which individual and corporate environmental choices are made. Although the emergence of environmental protection as a societal goal predates the Information Age, more visible harms, information on best practices, transparency, and the democratization of decisionmaking may reinforce the inculcation of environmental values and help to speed up the norm consolidation process.

Corporations in particular will face redoubled environmental scrutiny amidst greater transparency. As the social context within which they operate has evolved, many companies have developed sophisticated environmental programs. Business executives almost universally recognize that they must go beyond mere compliance with regulatory requirements in order to meet the high expectations of their customers, employees, and other stakeholders. ${ }^{265}$ Aided by the emergence of information-intensive environmental management systems, including ISO $14000,{ }^{266}$ the European Union's Eco-Management and Auditing Scheme, ${ }^{267}$ and the Global Reporting Initiative, ${ }^{268}$ a growing number of companies are making environmental protection or sustainability part of their business strategy and practice. ${ }^{269}$ Recent

closure Norms, 149 U. PA. L. REv. 1955 (2001) (arguing that norms and laws can help to reinforce each other).

265 See WORLD RES. INST., supra note 93 (explaining logic of voluntary environmental efforts and pressure to go "beyond compliance"); Leslie Carothers, The Environmental Manager: Integrating EHS into Manufacturing, ENVTL. F., Nov.-Dec. 1998, at 12.

266 See generally ISO 14001 and Beyond (Christopher Sheldon ed., 1997) (providing overview of environmental management system standards and requirements); see also Marc J. Epstein, Measuring Corporate Environmental Performance: Best Practices for Costing and Managing an Effective Environmental Strategy 128-29 (1996) (discussing role of ISO 9000 and ISO 14000 standards in global marketplace).

267 See Andrea Spencer-Cooke, From EMAS to SMAS: Charting the Course from Environmental Management to Sustainability, in ISO 14001 AND BEYOND, supra note 266, at 243.

268 See Global Reporting Initiative, GRI at a Glance, at http://www.globalreporting.org/ about/brief.asp (last visited Feb. 23, 2004) (identifying Global Reporting Initiative (GRI) as "multi-stakeholder process and independent institution whose mission is to develop and disseminate globally applicable Sustainability Reporting Guidelines" and providing access to GRI 2002 Guidelines); see also CERES Network for Change, Our Work: Overview, at http://www.ceres.org/our_work/main.htm (last visited Feb. 23, 2004) (stating that CERES encourages corporate environmental responsibility by working with companies on environmental reporting through GRI).

269 See Forest L. Reinhardt, Down to Earth: Applying Business Principles to ENVironmental Management (2000) (discussing corporate environmental pressures and providing strategies for managers to respond to those pressures); Andrew J. Hoffman, Institutional Evolution and Change: Environmentalism and the U.S. Chemical Industry, 42 ACAD. MGMT. J. 351, 363-64 (1999) (chronicling evolution toward environmental management in chemical industry); Hoffman, Trends in Corporate Environmentalism, supra note 97; see generally Green Ledgers: Case Studies in Corporate Environmental Accounting (Daryl Ditz et al. eds., 1995) (providing case studies on how business 
corporate scandals and the growing momentum for more "corporate responsibility" add to the values-based pressures for environmental care. ${ }^{270}$

Internet-based pressure groups 271 fuel the process of "information arbitrage" whereby multinational corporations face questions from everywhere about their actions anywhere. A company with a poor environmental record in a distant corner of its worldwide empire may find its reputation suffering globally, not just where the harm has occurred. For example, Rio Tinto, an Anglo-Australian mining concern, has come under attack in Europe and the United States for exposing workers to radiation at its uranium mine in Namibia and for causing cyanide to leach into nearby waters at its gold mine in Kalimantan, Indonesia. ${ }^{272}$

The rise of pressure groups also signals a sea change in how environmental groups organize and pursue their goals. Increased information flows will accelerate this shift. Some of these groups may even become "norm entrepreneurs," consciously working new avenues of information dissemination to reshape public values. ${ }^{273}$

The Internet can also be used to "roll up" public opinion in new ways, providing novel modes of collective action that may change the political context within which both companies and government operate. The international treaty banning landmines provides an

accounting practices can include information on environmental costs); Aris Solomon \& Linda Lewis, Incentives and Disincentives for Corporate Environmental Disclosure, 11 Bus. StRAT. ENV'T 154, 156-59 (2002).

270 See Michael Hopkins, The Planetary Bargain: Corporate Social ResponsiBILITY MATTERs (2003) (making case for changed business context that incorporates social responsibility); Stuart L. Hart, Beyond Greening: Strategies for a Sustainable World, HARv. Bus. Rev., Jan.-Feb. 1997, at 66 (making case that corporations should address environmental issues to achieve environmental and business sustainability).

271 See, e.g., CorpWatch, at http://www.corpwatch.org (last visited Feb. 23, 2004); Friends of the Earth, at http://www.foe.org (last visited Feb. 23, 2004); Global Witness, at http://www.globalwitness.org (last visited Feb. 23, 2004); Human Rights Watch, at http:// www.hrw.org (last visited Feb. 23, 2004); Stakeholder Democracy Network, at http:// www.stakeholderdemocracy.org (last visited Feb. 23, 2004).

272 See Danny Kennedy, PT Kelian: A Case Study of Global Operations, Corpwatch, at http://www.corpwatch.org/compaigns/PRT.jsp?articleid=622 (July 13, 2001) (investigating human rights and environmental abuses by Rio Tinto in violation of United National Global Compact).

273 See Cass R. Sunstein, On the Expressive Function of Law, 144 U. PA. L. REv. 2021, 2029-33 (1996) (discussing role of "norm entrepreneurs"); see also Dan M. Kahan, The Secret Ambition of Deterrence, 113 HARv. L. REv. 413, 448-51, 459-62 (1999) (describing how "expressive zealots" work to inculcate social norms and mold public values regarding capital punishment and gun control). 
example of how NGOs can organize, even globally, to bring political pressure to bear. ${ }^{274}$

\section{F. The End of "Do Nothing"}

In the Information Age, the number of cases where it makes sense to "do nothing" in the face of an environmental problem will shrink, perhaps significantly. In particular, as the optimal specificity of regulation is recalibrated based on the developments discussed above, a series of environmental practices and policy presumptions that have rationalized a "do nothing" environmental strategy will have to be rethought.

\section{No Visible Harm Means No Harm}

It is perhaps human nature to want to see, smell, hear, taste, or feel the purported link from harm to victim as a test of whether a problem is real. But the dismissal of harms that cannot be traced by the human senses is intellectually and ecologically curious if not indefensible. 275 Modern science permits us to detect many things that an average person cannot sense. ${ }^{276}$ Nevertheless, the maxim "out of sight, out of mind" continues to hold significant sway in the environmental realm, ${ }^{277}$ and the out-of-sight-means-no-big-harm legend frequently leads to narrow policy vision. Indoor air pollution provides a paradigmatic example of this phenomenon: No one sees the problem, but the harms from invisible gases and chemicals are real and increas-

274 Kenneth Anderson, The Ottawa Convention Barring Landmines, the Role of International Non-Governmental Organizations and the Idea of International Civil Society, 11 EUR. J. INT'L L. 91, 104-12 (2001) (discussing how NGOs achieved global-scale collective action).

275 See generally Dawes, supra note 164 (explaining how and why people ignore harms they cannot themselves perceive).

276 Technologies that detect unseen pollutants are being developed by universities, governments, and private companies. See Regulatory Reinvention (XL) Pilot Projects; Project XL Proposed Final Project Agreement: Progressive Insurance Company, 65 Fed. Reg. 39,614 (June 27, 2000) (describing efforts to fit automobiles with global positioning devices that can track automobile usage statistics). For a private-sector example, see John Medearis, Skies Finally Clearing for Pollution Control Firm, L.A. Times, Oct. 24, 1989, at 9A (describing firm that manufactures stack monitors).

277 See Cass R. Sunstein, Cognition and Cost-Benefit Analysis, 29 J. Legal Stud. 1059, 1064-73 (2000) (describing tendency to overregulate "on-screen" dangers because of failure to perceive trade-offs); Cass R. Sunstein, Economics \& Real People, 3 GREEN BAG $2 \mathrm{~d} \mathrm{397,} 400$ (2000) (describing "availability heuristic" and tendency of public to assign greater seriousness to those risks more easily called to mind or made visible through publicity); Wiener \& Graham, Resolving Risk Tradeoffs, in Risk versus Risk: Tradeoffs IN Protecting Health and the Environment, supra note 19, at 226, 234-35 (explaining public policy preoccupation with prominent and recent environmental disasters, to exclusion of other risks). 
ingly well documented. ${ }^{278}$ Because the risks are hard to perceive, the public is not clamoring for action. Thus, policymakers have tended to skip over the problem and assume that nothing needs to be done. A more data-driven approach to environmental problems combined with new "realization" effects likely will change this pattern.

\section{2. $\quad$ Limited Resource Pressure}

Pollution control and resource management costs money. If pollution intensity is low, no policy intervention may be justified. Similarly, if a resource is not scarce or otherwise under pressure, a regime of no controls may well be optimal. 279 In the early nineteenth century, when land seemed endlessly available in the American West, it made sense to permit "free" exploitation of available resources.

It stands to reason, then, that resources under pressure must somehow be allocated or managed to avoid overexploitation and market failure. The level of resource pressure determines when intervention is justified. But the level of resource pressure at which intervention is justified also depends on intervention costs, which are in part a function of information costs. As lower-cost, information-based resource management regimes become available, the point at which some sort of control system makes sense will emerge earlier (see Figure 1). If the cost of tracking fish stocks is low, the point at which it makes sense to intervene to protect a fishery from overexploitation will emerge earlier.

278 See Science Advisory Bd., Reducing Risk, supra note 75, at 10, 18, 23 (1990) (noting need to better assess and reduce human health risks associated with chemicals in environment).

279 Rose, supra note 85 , at 17 (discussing situations when "do-nothing strategy" might be appropriate); see Harold Demsetz, Toward a Theory of Property Rights, 57 AM. EcoN. REv. 347, 350-59 (1967) (discussing when control systems emerge). 


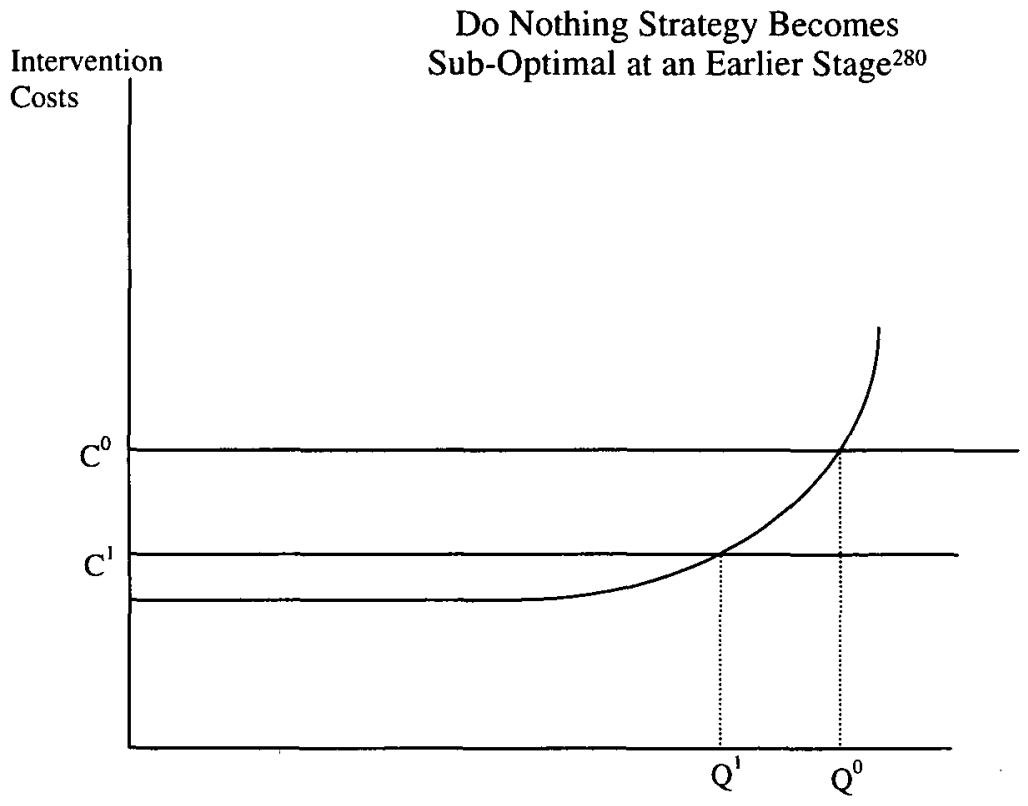

- As lower information costs drop the cost of intervention from $\mathrm{C}^{0}$ to $C^{\prime}$, the point at which intervention is justified shifts from $Q^{0}$ to $Q^{1}$

Resource pressure (cost of not managing the resource)

\section{FIGURE 1}

Distinct from the cost logic of earlier intervention, Information Age tools, which promote visibility and enhance the quantification of problems, also may make it easier to confront the entrenched expectations of those who have been taking advantage of below-cost resources. ${ }^{281}$ By making more vivid resource depletion or pollution that is overwhelming the assimilative capacity of an ecosystem, these tools highlight the changing circumstances and the need for behavior modification. Satellite imaging, for instance, makes deforestation and the harmful effects of those indiscriminately clearing the land much easier to track. ${ }^{282}$

280 This figure is a refinement of that in Rose, supra note 85, at 6 fig.1.

281 See Robert Sugden, The Economics of Rights, Co-operation, and Welfare (1986) (describing ways behavior can be modified without reliance on law and government); Robert C. Ellickson, Bringing Culture and Human Frailty to Rational Actors: $A$ Critique of Classical Law and Economics, 65 CHI.-KENT L. REv. 35-40 (1989) (highlighting differences in perceptions of losses compared to gains).

282 Indonesia, in response to such evidence, intervened to reduce rainforest clearing, in part by empowering NGOs to enforce forestry laws through private suits. See Simon SC 


\section{Assumption of Rough Reciprocity ("Live and Let Live")}

A corollary of the theory that abundant resources need not be managed is the notion that if pollution harms or natural resources consumed are roughly reciprocal, then the cost of intervention to internalize externalities is not justified. For example, if $A$ is causing ten units of harm to $B$ with the smoke from his coal furnace, but $B$ is causing ten units of harm to $A$ with the smoke from his coal furnace, it makes little sense (or so the theory goes) for $A$ to be required to pay $B$ for the ten units of harm only for $B$ to pay $A$ the same amount back again. The calculus that intervention is not justified seems especially strong when the harms are small and the cost of taking action to internalize the externality is not.

The reciprocity rationale is, however, a crude and increasingly inappropriate rule. First, the assumption of roughly equal harm across users is often wrong. In a few instances, such as breathing, the use of the resource (air) and the emissions released (carbon dioxide) is roughly equal across all individuals. But in other cases, some people use far more than their share of a collective resource or emit far greater than average pollution. Those who consume a much smaller fraction of common resources or emit less than others are disadvantaged by a presumed equality of impacts. For example, tailpipe controls under the Clean Air Act limit (but do not eliminate) vehicle emissions, but there has been no serious attempt to require compensation for the not-insubstantial residual harm from exhaust. The harm caused is assumed to be more or less reciprocal to the extent that everyone in the United States drives a car. ${ }^{283}$ But if Amory drives a highly fuel efficient hybrid car (and sometimes rides his bike) while Betty drives a gas-guzzling sports utility vehicle, their air pollution impacts are by no means roughly equal. Betty's emissions will certainly be three or four times greater than Amory's and might be as much as ten times higher. ${ }^{284}$

Second, the assumption of rough reciprocity, which focuses our attention on the balance of emissions between Amory and Betty as drivers, distracts us from the underlying allocative inefficiency. Specifically, when emissions are not fully priced, the consumption by both Amory and Betty of the polluting good (cars) is subsidized relative to

Tay, The Southeast Asian Fires: The Challenge of International Law and Development, 11 Geo. INT'L ENVTL. L. Rev. 241, 251-54 (1999).

283 See generally KRIER \& URSIN, supra note 24.

284 See Dept. Of ENERGy, ENERGy EFficiency AND Renewable Energy, at http:// www.fueleconomy.gov (last visited Feb. 23, 2004) (providing information about greenhouse gas emissions, gas mileage, air pollution ratings, and safely slatistics for new and used cars and trucks). 
other goods (e.g., bicycles). As a result, polluting goods and activities (driving gasoline-powered cars) are overconsumed relative to nonpolluting ones (riding bicycles) or less polluting ones (driving hybrid vehicles). ${ }^{285}$ If Amory and Betty faced the full costs of driving, both of them might choose to drive less, make more efficient use of their cars, or demand vehicles that generate less pollution.

As the cost of tracking pollution and pricing externalities falls, it will become economically rational to address environmental harms in a larger number of cases. In fact, as the transaction costs of pollution monitoring approach zero, the number of cases where presumed reciprocity makes sense will also shrink toward zero. Ultimately, only in cases where harms are truly reciprocal and de minimis will it be efficient to ignore them.

\section{Small Equals Zero}

Beyond disregarding presumed reciprocal harms, the existing environmental regime often treats small harms as unimportant and thus not worth addressing. ${ }^{286}$ When these small sources are aggregated, however, the impact can be quite large. Thus, if Betty's car were the only one on the roads, it would not merit any attention. But alongside 200 million other vehicles on America's highways, the cumulative air pollution from vehicles looms very large. ${ }^{287}$ In fact, the cumulative impact of small-source emissions today represents the bulk of the remaining pollution problems in many areas. ${ }^{288}$

As with other cases where a "do nothing" response has been presumed to be appropriate, the logic for ignoring small harms collapses as the cost of tracking and internalizing them drops. As transaction

285 See BAUMOL \& OATES, supra note 14, at 14-23 (describing limitations of free market pricing systems wherein environmental externalities are not reflected in costs and prices paid).

286 See Sunstein, supra note 19 , for a discussion of the tremendous insensitivity to low probability events, explained by both a human inability to comprehend differences among low probabilities, and a psychic desire to establish "safety thresholds," thereby eliminating anxiety over real, but low, probability risks.

287 Americans cumulatively drive more than two trillion vehicle-miles per year. Fed. Highway admin., Office of Highway Policy Info., Traffic Volume Trends, at http://www.fhwa.dot.gov/ohim/tvtw/tvtpage.html (last visited Feb. 23, 2004) (providing monthly reports based on hourly traffic count data).

288 See Office of Air Qualtry Planning and Standards, Envtl. Prot. Agency, National Air Quality and Emissions Trends Report, 1997 (1998), at http:// www.epa.gov/oar/aqtrnd97/toc.html; OfFice of AIR Quality Planning and STANdards, Envtl. Prot. Agency, Nattonal Air Quality and Emissions Trends REPORT, 1998 (2000), at http://www.epa.gov/oar/aqtrnds.htmi; see also OFFICE OF AIR Qualtry Planning and Standards, Envtl. Prot. Agency, National Air PolluTANT EMISSION TRENDS: 1900-1998 (2000), at http://www.epa.gov/ttn/chief/trends/ trends98/index.html. 
costs fall, the efficiency gains from internalizing the externality will outweigh the administrative burden in more and more circumstances.

\section{$\mathrm{V}$ \\ Motivating Information Production}

As the prior Parts of this Article demonstrate, data and information availability shape our institutional options for addressing environmental harms. Reciprocally, our institutional choices define what data and information is available to decisionmakers. Given the centrality of information to environmental problemsolving, more policy emphasis should be given to driving data and analysis into the environmental rights marketplace, the regulatory process, and the hands of consumers. ${ }^{289}$

\section{A. Driving Environmental Information into the Decisionmaking Realm}

In developing incentives for information production, it is useful to understand why the requisite data and/or analysis is not now available. The thinking to date has been dominated by an economics perspective that sees such information in terms of whether it is a public or a private good and whether or not it is rival in consumption. ${ }^{290}$ These dichotomies are of limited analytic value in the environmental domain. A broader set of motivations must be recognized.

It is an oversimplification to see environmental knowledge as purely a public good. Environmental data often are privately generated and not publicly shared. Such information may be guarded for commercial advantage or as a shield against government action. Consider, in this regard, the cutting-edge, pollution-reducing seeds developed by biotechnology companies. These "knowledge" products are not rival in consumption the same way that an apple can be eaten by

289 Ironically, the recent trend has been to disinvest in data production. Congress abolished its own Office of Technology Assessment in 1995. Legislative Branch Appropriations Act 1996, Pub. L. No. 104-53, § 112, 109 Stat. 468, 525-26 (1995). Congress also has refused fully to fund the National Biological Survey. See Charles Oliver, A New Push on the Environment?, Investor's Bus. DaILy, Dec. 5, 1996, at A1 (noting Clinton Administration's efforts to use administrative regulations to fund and catalogue plant and animal species in United States, in light of Congress's refusal to fund National Biological Survey). The National Biological Survey (later renamed the National Biological Service) was terminated in a 1996 spending bill and transferred in part to the Geological Survey. See Balanced Budget Downpayment Act I, Pub. L. No. 104-99, § 123, 110 Stat. 26, 32-33 (1996).

290 See Adam M. Brandenburger \& Barry J. NalebufF, Co-opetition 198-227 (1996) (explaining how dynamics of information generation, nondisclosure, and use can impact business strategy); Graciela Chichilnisky \& Geoffrey Heal, Introduction, in ENvIRONMENTAL MARKeTs, supra note 50, at 1, 3-4. 
only one person. But neither are they pure public goods in the strong sense, like national defense, of being not only nonrival, but also "nonexcludable." Access to knowledge is often limited and controlled by those who hold it for economic advantage.

Significant amounts of environmental data, analysis, and information are nevertheless publicly generated. The panoply of reports put out each year by the EPA and other government agencies attest to this fact. A great deal of knowledge also is produced in public research centers (i.e., the National Institutes of Health) or publicly funded academic institutions. In addition, noncommercial private research centers and universities generate significant data, information, and learning (often with a degree of public funding). This reality comports with economic theory, which suggests that to the extent environmental information has a public good element, it will be underproduced by the private marketplace. Government funding helps to overcome this market failure.

Environmental knowledge therefore needs to be understood in a more nuanced manner. A more useful analytic framework focuses on whether the data, information, and analysis needed for a functioning market or sound policymaking exist and whether this knowledge is viewed as a strategic asset. A further distinction can be drawn between information that is held close to keep it out of the hands of the government versus that which is not shared because of its value to competitors. In each case, it is important to specify: (1) what information gaps plague decisionmaking; (2) who is best positioned to fill the gap in question (i.e., who is the least-cost information provider); and (3) what incentives are needed to induce the production of the requisite information.

\section{B. Critical Environmental Information Does Not Exist}

In many cases, essential information or knowledge is simply not available. These gaps can be traced to: (a) technical and analytic limitations, which translate into cost barriers; (b) market failures; and (c) institutional shortcomings. Structuring incentives to overcome these barriers is critical.

\section{Cost Barriers}

As discussed earlier, the optimal specificity of regulation is a fundamental issue in the environmental realm. Sometimes we know what data we would like to have to make a policy decision, but we choose not to obtain the information because the cost of acquisition would not be justified by the anticipated gains in policy precision. It would 
be technologically feasible, for example, to stop each car on the road each day and measure its particulate emissions. But the cost of undertaking such a detailed monitoring program has been seen as prohibitively expensive. In other cases, the information production process is simply slow. Precise levels of chemical exposure and pesticide safety have not yet been established because generating the requisite data takes time and money. 291

Some environmental knowledge gaps naturally will be filled over time. Although the world is dynamic and new challenges constantly are emerging, knowledge is cumulative. ${ }^{292}$ Ongoing investments in environmental data and analysis broaden the information base for future decisionmaking. And, as discussed earlier, advances in allied fields (statistics, biology, chemistry, epidemiology, meteorology, etc.) constantly strengthen the foundations for environmental decisionmaking. Technical, scientific, and analytic constraints will therefore soften over time as a natural outgrowth of the accumulation of knowledge.

The pace at which new data and relevant knowledge is generated can be affected, however, by institutional design. Where the costs of obtaining information currently exceed the benefits to the regulated community, incentives can be developed to lower the costs of information gathering or to increase the benefits that can be obtained from the data and knowledge to be generated.

In some instances, scale economies can be achieved by centralizing the data collection or analytic processes. The EPA's Toxic Release Inventory demonstrates this potential. ${ }^{293}$ In this spirit, some observers have called for an environmental "super study" to fill critical data gaps. ${ }^{294}$ But a government monopoly on data generation may not be advisable. Competition and decentralization of the data gathering, information generation, and analytic processes may pro-

291 Lyndon, supra note 38, at 1810-17 (concluding that public intervention is necessary "to ensure that accurate data are produced and distributed optimally"); see also Thomas $\mathrm{O}$. McGarity, Beyond Buckman: Wrongful Manipulation of the Regulatory Process in the Law of Torts, 41 WAshBuRn L.J. 549, 559-63 (2002) (explaining how pesticides evade safety testing); McGarity \& Shapiro, supra note 40 , at 873-82.

292 In some cases, theories unravel over time as we determine that they were based on faulty analysis. But more often, knowledge is refined as more precise data and thinking become available. Thus, the technical gap trends downward over time. See, e.g., Robert Wright, Mr. Order Meets Mr. Chaos, Foreign Pol'Y, May-June 2001, at 50, 52-53 (arguing that history is process that has "direction"). But see THOMAs Homer-Dixon, THE INGENuITY GAP 1-4 (2000) (arguing that world is getting more complex and that information gaps are worsening rather than improving).

293 See Karkkainen, supra note 23, at 294 (discussing information generation through TRI).

294 Lyndon, supra note 38, at 1837-41. 
duce better results. ${ }^{295}$ The government-versus-private-sector battle to map the human genome demonstrates this potential. ${ }^{296}$ In other cases, "gatekeepers" might be identified who are positioned to gather data from potential polluters. The obligations of banks and lenders under CERCLA provides an example of how this mode of information production operates. ${ }^{297}$ Case-by-case analysis and judgment about whether cooperation or competition is more likely to produce efficient data generation will be required.

Ensuring that the opportunities for improved information generation systematically are explored in the regulatory context will require more effort to identify the "least cost" information generators and to structure society's environmental rules to deliver an optimal degree of relevant information to decisionmakers at the lowest possible cost.

A number of proposals might be considered in this regard. One idea would be to fold a required "information gap analysis" into the existing regulatory process. This could be done by Executive Order, as a supplement to the existing requirements for regulatory impact and cost-benefit analyses. ${ }^{298}$ Thus, for example, in promulgating new regulations under the Clean Air Act, the EPA would be required to factor into its rulemaking process some overt consideration of: (1) what information is needed to make sound air pollution policy decisions going forward; (2) what data and analysis is missing or incomplete; (3) who is best positioned to generate this information; and (4) what incentives could be adopted to ensure that the requisite data and information gets collected and analyzed.

The Office of Information and Regulatory Affairs (OIRA) in the White House Office of Management and Budget might be asked to take the lead in reviewing the information analyses produced by the regulatory agencies and in identifying opportunities to drive informa-

295 Cf. Esty, supra note 21, at 605-52 (assessing benefits of regulatory centralization versus decentralization more generally).

296 See Courtney Humphries, Public, Private Drafts of Genome Found Comparable, Focus, News From Harv. Med., Dental \& Pub. Health Schs. (Feb. 23, 2001), at http:/ /focus.hms.harvard.edu/2001/Feb23_2001/genetics.html (pointing out rivalry of public and private enterprises has spurred and improved human genome project).

297 Salzman, supra note 31, at 472-75 (describing how imposition of strict liability for environmental contamination on range of potentially responsible parties creates "gatekeepers" with low-cost and ready access to information relevant to corporate wrongdoing).

298 See Exec. Order No. 12,866, 3 C.F.R. 638 (1993), reprinted as amended in 5 U.S.C. $\S 601$ (2000); Exec. Order No. 12,291, 3 C.F.R. 127 (1981), reprinted as amended in 5 U.S.C. $\S 601$ (2000) (revoked by Exec. Order No. 12,866, 58 Fed. Reg. 51,735 (Sept. 30, 1993)). The White House Council on Environmental Quality has issued various guidance documents on how agencies should deal with uncertainties. See, e.g., 40 C.F.R. $\$ 1502.22$ (1991); 40 C.F.R. $\$ 1502.22$ (b) (2003); see also Farber, supra note 23, at 164-66 (discussing $\mathrm{CEQ}$ efforts to address information gaps). 
tion into the decisionmaking process. OIRA also might be charged with developing a broad-gauge study of persistent information gaps and possible strategies for filling them.

A further refinement might entail amendment of the Administrative Procedure Act so that explicit consideration is given to identifying and filling information gaps. Making the analytic foundation for decisionmaking part of the notice-and-comment process, for example, would engage a broader set of actors in thinking through the knowledge-generation questions that are part of any regulatory action.

\section{Market Failures}

Even where the social benefits of generating environmental information exceed the social costs, the private costs to the information generator may exceed her private benefits, and the information will not be produced. For instance, while society would benefit from a better understanding of the range of endangered species, the landowners on whose property these species reside might well bear costs from habitat protection obligations that exceed any private benefits that they could anticipate from better knowledge. ${ }^{299}$

To the extent that the presence of endangered species may translate into land use restrictions, those best positioned to generate information (i.e., the regulated industry or persons) have no reason to produce or share what is needed and perhaps even an incentive to destroy the data. Indeed, the information-gap-ridden status quo advantages some interests, particularly those which benefit from existing below-cost resource use or the underpriced externalization of pollution harms.

Such asymmetries between those who bear the costs and those who obtain the benefits of environmental information generation lead to chronic underinvestment in relevant data and analysis. ${ }^{300}$ Intervention to change the information-generation calculus of these actors, and of the least-cost information generators more generally, therefore is required. Gaining support for wetlands mapping or endangered species tracking may require payments to property owners with land

299 See Jacqueline L. Brown, Preserving Species: The Endangered Species Act Versus Ecosystem Management Regime, Ecological and Political Considerations, and Recommendations for Reform, 12 J. ENVTL. L. \& LrTIG. 151, 246-47 (1997) (noting that perverse incentives arise under existing regulatory scheme); Andrew G. Frank, Note, Reforming the Endangered Species Act: Voluntary Conservation Agreements, Government Compensation and Incentives for Private Action, 22 Colum. J. ENVTL. L. 137, 145-46 (1997) (noting that current ESA regulations give landowners incentive to destroy or hide species on their land or develop land before ESA regulations are in place).

300 See Lyndon, supra note 38 , at $1810-17$ (discussing disincentives to production of chemical toxicity and exposure data). 
containing resources that generate community benefits. Subsidizing positive externalities would reverse the current incentive to hide such resources and to fight information production efforts. ${ }^{301}$

In some cases, the underlying market failure could be corrected by subsidizing information generation more broadly as a public good. A stronger budget commitment to data generation and analysis should therefore be seen as a priority for the EPA, the Fish and Wildlife Service, and other pollution control and resource management agencies. ${ }^{302}$ Similar investments in environmental information generation should be made at the local, state, regional, and global scales.

The benefits of generating and releasing data and knowledge also can be increased. Under current legal rules, companies often fear that having information on their environmental problems or the risks associated with their activities will create legal exposure rather than benefits. In particular, they fear that the government will use this information against them. The existing incentives could, however, be realigned. ${ }^{303}$ Companies could be required, for example, to disclose more fully their environmental liabilities and potential risks in their annual reports or in their annual $10-\mathrm{K}$ filings, and in return, environmental enforcement fines might be reduced for companies that can show that they have appropriate environmental management and measurement systems in place. ${ }^{304}$ The EPA's new "Audit Policy" tries to reshape the information-generation incentives, but empirical evidence suggests that the EPA has not gone far enough to assuage cor-

301 Carol Rose suggests a variety of incentives to induce private property owners to cooperate with environmental regulations. Many of these tools, such as tax breaks, might be used to promote environmental information generation. Carol M. Rose, Property Rights and Responsibilities, in Thinking ECOlogically, supra note 31, at 49, 56.

302 As noted above, the trend has been in the opposite direction. See supra note 289; see also Robert L. Glicksman \& Stephen B. Chapman, Regulatory Reform and (Breach of) the Contract With America: Improving Environmental Policy or Destroying Environmental Protection?, 5 KAN. J.L. \& PuB. PoL'y 9, 19 (1996) (criticizing elimination of Office of Technology Assessment and efforts to eliminate National Biologic Survey); Dennis Hayes, Environmental Law and Millennial Politics, 25 ENVTL. L. 953, 958 (1995) (criticizing special interest groups' lobbying Congress to cut knowledge generation).

303 See Alexander S.P. Pfaff \& Chris William Sanchirico, Environmental Self-Auditing: Setting the Proper Incentives for Discovery and Correction of Environmental Harm, 16 J.L. ECON. \& ORG. 189, 191-93 (2000) (modeling information incentives of EPA's corporate environmental audit policy). The new Sarbanes-Oxley Act, requiring top executives to certify that their financial statements are accurate (including references to environmental liabilities and issues) could provide an impetus for change. See Michael Saul \& Katherine P. O'Halleran, The Impact of Sarbanes-Oxley on Environmental Management, NAT. Resources \& Env'T, Fall 2003, at 76.

304 Cf. Jennifer Arlen \& Reiner Kraakman, Controlling Corporate Misconduct: An Analysis of Corporate Liability Regimes, 72 N.Y.U. L. REv. 687, 742-44 (1997) (showing how conditioning fines on monitoring can shape corporate incentives for environmental care). 
porate fears that self-generated information will be more harmful than helpful. ${ }^{305}$

At the same time, environmental disinformation needs to be disciplined. Government officials-through the Federal Trade Commission and similar state agencies-need to be vigilant about policing product claims relating to environmental quality. ${ }^{306}$ If misinformation and false promises of biodegradability, recycled content, recyclability, and the like are not prosecuted, consumer confidence in environmental claims will falter. ${ }^{307}$ Procedures to screen against information overloads or disinformation designed to confuse the consumer or the policy process may also be required. The risk of misinformation or confusion seems especially serious in the context of the Internet and e-commerce. Over time, reliable information filters and content evaluators may appear, ${ }^{308}$ but some interim governmental support for the integrity of this emerging marketplace may be needed.

\section{Legal and Institutional Failures}

While legal instruments can spur information generation, some laws actively reward ignorance. U.S. pesticide laws and regulations (notably, the Federal Fungicide, Insecticide, and Rodenticide Act (FIFRA) ${ }^{309}$ ) allow companies to keep their products on the market until regulators prove them to be harmful. Companies have no affirmative duty to demonstrate the safety of their products and thus little incentive to do detailed risk analyses until the government raises a question about a particular product. ${ }^{310}$ Beyond FIFRA, the Toxic

305 Alexander S.P. Pfaff et al., Big Field, Small Potatoes: An Empirical Assessment of EPA's Self-Audit Policy, 23 J. Pol'y Analysis \& MgmT. (forthcoming 2004).

306 Without government regulation, misleading or false claims of environmental product attributes are likely to proliferate, rendering environmental labeling meaningless. In 1991, for example, the State of Washington reached a settlement with Mobil Chemical Company regarding advertising "degradable" claims regarding Hefty brand trash bags. The Hefty packaging seemed to promote the product as environmentally-sensitive and biodegradable although the bags actually were unlikely to decompose in landfills where there is no sun exposure. See June Camille Bush Raines, The Green Giant: Environmental Marketing Claims, 45 OKLA. L. Rev. 689, 698-703 (1992).

307 See ReINHARDT, supra note 269, at 39-43 (discussing eco-label schemes).

308 An example of such a phenomenon is the development of technologies designed to filter out violent or sexually explicit television shows or websites. See Jack M. Balkin, Media Filters, The V-Chip, and the Foundations of Broadcast Regulation, 45 Duke L.J. 1131 (1996); C. Dianne Martin \& Joseph M. Reagle, An Alternative to Government Regulation and Censorship: Content Advisory Systems for the Internet, 15 CARDozo ARTs \& ENT. L.J. 409 (1997) (proposing Internet advisory rating system).

3097 U.S.C. $\S 136$ (a) (2000) (requiring pesticide manufacturers to present "a full description of the tests made and the results thereof" to register pesticide upon request by administrator).

310 Percival ET AL., supra note 4, at 385-87, 474. 
Substances Control Act (TSCA), ${ }^{311}$ the Resource Conservation and Recovery Act (RCRA), ${ }^{312}$ the Comprehensive Environmental Response, Liability, and Cleanup Act (CERCLA) or "Superfund,"313 and a number of other laws are structured so that potential harm causers find that it is in their own interest not to know about a problem or not to explore the full extent of a potential harm. Such disincentives for information generation represent a critical form of regulatory failure.

Companies have no incentive, moreover, to look for harms where there are no laws or regulations. Thus, many areas of potential risk, such as indoor air pollution, go unattended because there is no reason to invest in harm identification, impact evaluation, mitigation or abatement. The problem again can be traced to the structure of environmental laws, particularly the limited coverage of the current patchwork of statutes.

Strategies exist, however, for reversing the incentives for ignorance. In a number of circumstances, such as FIFRA, legal "burden shifting" could be undertaken. California's Proposition 65 provides a good example of how this might work. ${ }^{314}$ Under the California toxics statute, the burden of proving safety shifts from the government to the producers of products that may be carcinogenic or may expose the public to reproductive hazards. ${ }^{315}$ Rather than allowing manufacturers to sell their wares until the government proves they are unsafe, Proposition 65 threatens significant legal penalties for the marketing of any product that later is found to create greater than a $10^{-5}$ additional risk of harm. The California law thus transforms the incentives for data generation. ${ }^{316}$ By placing the burden on industry to prove the safety of its products, California has generated a vast quantity of information about chemical risks. 317 From "White Out" correction

31115 U.S.C. $\$ \S 2601-2692$.

31242 U.S.C. $\$ \$ 6901-6992(k)$.

313 Id. $\$ \S 9601-9675$.

314 Safe Drinking Water and Toxic Enforcement Act of 1986, Cal. Health \& SafeTY CODE $§ 25249.5$ (West 2003).

315 See David Roe, An Incentive-Conscious Approach to Toxic Chemical Controls, 3 Econ. Dev. Q. 179, 180-82 (1989). But see Karkkainen, supra note 23, at 345-47 (arguing that Proposition 65 does not generate useful streams of data); Michael Barsa, Note, California's Proposition 65 and the Limits of Information Economics, 49 STAN. L. Rev. 1223 (1997) (emphasizing that, while Proposition 65 fails to educate consumers about product's risk level, such warning statutes do provide manufacturers with incentives to improve safety of their products).

316 This approach can be seen as an application of the Precautionary Principle. See Daniel Bodansky, Scientific Uncertainty and the Precautionary Principle, ENV'T, Sept. 1991, at 4,5 .

317 David Roe, Toxic Chemical Control Policy: Three Unabsorbed Facts, 32 EnvtL. L. REP. 10,232, 10,235 (2002). 
fluid to the lead solder in tuna fish cans, dozens of products have been taken off the market or reformulated to reduce their public health risks. ${ }^{318}$

A related approach involves the careful structuring of "default rules" and legal presumptions. A presumption against the party in the best position to produce relevant data creates an incentive to resolve uncertainties. Creating a "duty to test" or a presumption that any new product must have its safety demonstrated before being allowed into the marketplace changes the benefit-from-delay dynamic. Such a rule creates an incentive for producers to generate safety data, reduce uncertainty, and speed their product to market. Fundamentally, if uncertainty were to carry a clear commercial price tag, data on environmental risks would be generated as companies seek to reduce their cost burdens. ${ }^{319}$

Changes in accounting rules also may encourage information production. Under current Federal Accounting Standards Board rules, environmental liabilities-such as potential responsibility for Superfund cleanups that are "contingent" and "unquantified"-need be mentioned only in passing in audit statements. ${ }^{320}$ In contrast, more well-documented liabilities require fuller explanations and the setting aside of reserves. Similarly, Securities and Exchange Commission disclosure rules sometimes discourage companies from knowing the full extent of their environmental liabilities because more complete infor-

318 Percival ET AL., supra note 315, at 478-82; see also Roe, supra note 315 , at 181,185 n.27a (noting that under TSCA, federal government had "applied quantified testing limits" to only seventeen chemicals between 1976 and 1988). California thus managed to draw bright lines for more chemicals in the first twelve months following passage of Proposition 65 than the federal government had managed to accomplish in twelve years, under the supposedly omnibus Toxic Substances Control Act. Id. at 181.

319 The European Union's REACH program (Registration, Evaluation, and Authorization of Chemicals) moves in this direction. Under recently promulgated regulations, manufacturers must prove the safety of their products if they are to stay on the market. More than 50,000 chemicals could be affected by this new regulatory default rule.

See The New EU Chemicals Legislation-REACH, at http://europa.eu.int/comm/enterprise/chemicals/chempol/whitepaper/reach.htm (last visited Feb. 23, 2004); see also The Forum, The Long Arm of REACH: A Bold Proposal from the EU on Chemical Safety, ENVTL. F., Sept./Oct. 2003, at 46.

320 Financial Accounting Standard No. 5 requires tabulation of a contingent liability if it is likely to occur and if the amount of loss can be reasonably estimated. Although there have been recent efforts to clarify how this standard applies to environmental liabilities (including specific guidance outlined in Staff Accounting Bulletin No. 92), companies are allowed to make their own determination of whether an environmental liability must be reported under this standard with very little oversight. See Susan Millington Campbell \& Carol E. Remy, Disclosure Requirements and Securities Laws, N.Y.L.J., Oct. 30, 1997, at S4. 
mation triggers broader disclosure requirements. ${ }^{321}$ A 1998 study on disclosure of environmental lawsuits in 10-K filings found a nonreporting rate of $74 \%$ for $1996-97.322$ Revised rules could change these incentives.

Finally, and most generally, corporate incentives could be restructured by a shift from a command-and-control regulatory strategy to a "command and covenant" model. As Elliott suggests, such an approach puts the burden on corporations to measure and report on the public health or ecological harms they, are causing and then to negotiate reduction targets. ${ }^{323}$

Additional information failures may arise because the entity best positioned to undertake environmental decisionmaking is not the same entity that is best positioned to do environmental data gathering or processing. As noted earlier, where externalities do not extend beyond a relatively small jurisdiction, local or state decisionmakers may be better positioned than distant federal regulators to understand all of the relevant circumstances and to make appropriate tradeoffs. But given the scale economies in some dimensions of environmental information generation, devolution of information-generating responsibilities to local units may be inappropriate. A prerequisite to successful devolution of environmental decisionmaking might well be the creation of a National Institute for the Environment, which would do the requisite background data collection and analysis. ${ }^{324}$ Hybrid institutional structures and multi-tier regulatory approaches which divide information gathering and analysis responsibilities among levels of government thus may be the optimal solution.

321 See generally Michael Gollub, Reducing Uncertainty in Environmental Disclosure: Why the Securities and Exchange Commission Should Return to the Basics, 4 ENvTL. L. 311 (1998) (providing overview of SEC rules on disclosure of environmental liabilities).

322 Memorandum from Mary Kay Lynch \& Eric V. Schaeffer to OECA Office Directors, Guidance on Distributing the "Notice of SEC Registrants' Duty to Disclose Environmental Legal Proceedings", reprinted in EPA Administrative Enforcement Actions (Jan. 19, 2001), at http://www.epa.gov/compliance/resources/policies/incentives/programs/secguid-distributionofnotice.pdf.

323 Charnley \& Elliott, supra note 30, at 170, 183-85; see also Orts \& Deketelaere, supra note 100, at 5-11 (detailing development of regulatory contracts in United States and Europe); Elliott \& Charnley, supra note 101, at 49-50 (explaining how this approach creates incentives for improved measurement and risk-comparison technology, and may result in large efficiency gains in regulatory system).

324 A number of attempts have been made to create a National Institute for the Environment (NIE). For example, the 1997 "Sound Science for the Environment" bill called for the creation of the NIE as an independent organ of the National Science Foundation. H.R. 2914, 105th Cong. (1997). 


\section{Information Withheld}

In some cases, environmental information exists, but those who have it choose not to share it. Companies may decide not to be forthcoming with environmental information if they see themselves in an adversarial relationship with regulators. ${ }^{325}$ In addition, businesses that see economic opportunities in their superior environmental data, analysis, or technologies will also treat environmental knowledge as a strategic asset and a potential source of competitive advantage.

\section{Antagonism Toward Government}

A number of other long-established policy practices exacerbate the tension between regulators and the regulated community and lead to a stifling of information availability. Notably, the threat of prosecution for shortcomings identified in company environmental audits has chilled many corporations' interest in measuring and documenting the environmental problems they face. ${ }^{326}$ A "safe harbor," which gives companies a clear incentive to undertake rigorous environmental selfevaluations, would therefore be useful. ${ }^{327}$

Ayres and Braithwaite have argued that if our regulatory approach were less contentious, companies would be much more likely to bring forward the information they have about their polluting

325 See Pfaff \& Sanchirico, supra note 303, at 191, 207 (discussing chill created where self-auditing and disclosure make inspections and fines more likely without generating any offsetting advantages); see also supra notes 303-06 and accompanying text.

326 See REINHARDT, supra note 269, at 172 (spelling out risk that corporate environmental audits could aid prosecutors); Frank Friedman, Is This Job Worth It?, ENVTL. F., May/June 1991, at 20, 23 (raising specter that audits which identify unresolved problems could create legal exposure); Susan J. Spicer, Turning Environmental Litigation on its E.A.R.: The Effects of Recent State Initiatives Encouraging Environmental Audits, 8 VILL. ENVTL. L.J. 1, 4 (1997) (noting that "[t] he regulated community fears that prosecuting authorities will improperly request and use internal environmental audits to bring civil and criminal actions against parties").

327 The EPA's present policy limits the incentives that regulators can use to encourage companies to pursue internal environmental audits. See Incentives for Self-Policing: Discovery, Disclosure, Correction and Prevention of Violation, 60 Fed. Reg. 66,706, at III(B)(1) (Dec. 22, 1995). Many states, however, have adopted laws or policies that encourage environmental audits by limiting penalties associated with infractions discovered during such audits or offering other forms of regulatory relief. For an overview of these EPA and state policies, see Paulette L. Stenzel, Can the ISO 14000 Series Environmental Management Standards Provide a Viable Alternative to Government Regulation?, 37 AM. Bus. L.J. 237, 267-68 (2000). For a view on the potential harms of such audits, see generally David A. Dana, The Perverse Incentives of Environmental Audit Immunity, 81 IowA L. Rev. 969 (1996) (arguing that such audit immunity weakens incentives for care). 
activities and opportunities for mitigation. ${ }^{328}$ Elliott's call for a shift in regulatory focus emanates from the same spirit. ${ }^{329}$

One way around the strategic withholding of information is through environmental "contracting." 330 If entities within the regulated community were allowed to propose ways to reduce environmental risk, they would have an incentive to generate and share data. Environmental contracting as a strategy to overcome information failures and to promote better environmental protection at a lower cost long has been used in the Netherlands. ${ }^{331}$

Similar approaches have been tried in the United States, but on a very modest scale. In particular, the EPA's XL initiative promised a degree of regulatory flexibility for companies that committed to "beyond compliance" performance. ${ }^{332}$ The limited success of this effort highlights the need for careful program design and clear statutory authority. ${ }^{333}$

\section{Competitive Positioning}

When corporations withhold information because they see strategic advantage in keeping it from competitors, a different approach is required. Properly harnessed, market forces can promote a degree of environmental information sharing, particularly by those with successful pollution control procedures or equipment. Companies with

328 Ian Ayres \& John Braithwaite, Responsive Regulation: Transcending the Deregulation Debate 45-46 (1992).

329 See Charnley \& Elliott, supra note 30 , at 170, 179-85.

330 See Orts \& Deketelaere, supra note 100, at 5-11.

331 As Stewart notes, in the Netherlands

[e]ach industry is allocated a designated share of the required reductions and improvements. The responsible government authorities and a number of industry groups ... have signed or are currently negotiating contracts in which the industry agrees to achieve the overall targets assigned to it. In return, the government agrees to substitute the contractual arrangements for the pollutant-by-pollutant regulations otherwise applicable . . . .

Richard B. Stewart, Environmental Regulation and International Competitiveness, 102 YALE L.J. 2039, 2090 (1993).

332 Dennis D. Hirsch, Bill and Al's XL-ent Adventure: An Analysis of EPA's Legal Authority to Implement the Clinton Administration's Project XL, 1998 U. ILL. L. REv. 129, 130; see also Freeman, supra note 93, at 55-65.

333 See Thomas E. Caballero, Project XL: Making It Legal, Making It Work, 17 STAN. ENvTL. L.J. 399, 412-34 (1998) (discussing obstacles to Project XL's implementation, including legal unicertainty of EPA's authority); Bradford C. Mank, The Environmental Protection Agency's Project XL and Other Regulatory Reform Initiatives: The Need For Legislative Authorization, 25 Ecology L.Q. 1, 24-30 (1998) (identifying Project XL's problems including legal uncertainty); Lawrence E. Susskind \& Joshua Secunda, The Risks and the Advantages of Agency Discretion: Evidence From EPA's Project XL, 17 UCLA J. ENvTL. L. \& PoL'y 67, 95-103 (1998) (examining institutional obstacles facing EPA's XL program). 
superior emissions control strategies or technologies would have an incentive to "share" their knowledge if they could sell their solutions to ail parties in the marketplace. Likewise, where a company develops an environmentally superior product, it may make that information known to its potential customers, even though competitors will hear about the product and may try to copy it.

"Green" product attributes may contribute to growth in market share or greater profitability, especially among the environmentallyconscious segment of the buying public. There is growing evidence, moreover, that a small number of informed "comparison shoppers" can shape the product offerings, and environmental qualities of goods in the marketplace. ${ }^{334}$ Thus, an environmental "blessing" (perhaps from environmental groups or others who take up the opportunity to act as "screeners") or a strong score from environmental rating agencies may prove decisive in the market. ${ }^{335}$ To the extent that such programs are encouraged, companies may find that the competitive value of disclosing environmental data outweighs the strategic value of withholding such information.

\section{CONCLUSION}

Effective pollution control and natural resource management require a great deal of information. Successful environmental protection depends on recognizing and analyzing the spectrum of information gaps to be filled. Identifying which institutional structures best fill information gaps under particular circumstances also should be understood as a central question in environmental law. Because information gaps loom large as a source of transaction costs, they shape our perceptions about the optimal means as well as the most desirable ends of environmental policymaking.

Information Age technologies promise to change the environmental- protection calculus in fundamental ways. Computers, the Internet, advanced communications devices, sensors, and other innovations make it easier and cheaper to collect, analyze, and disseminate data, generate knowledge, and fill information gaps. Harms will become more visible and easier to trace. Environmental analysts will be better positioned to model effects and predict impacts. An enhanced ability to measure harms and quantify results promises to

334 See Lyndon, supra note 38 , at 1831-32.

335 Historically, the Underwriters Laboratory stamp of approval or the Good Housekeeping Seal of Approval provided powerful market signals of quality. Similar product "screeners" are emerging in the e-commerce setting, some with environmental overtones. See, e.g., Idealswork Website, at http://www.idealswork.com (last visited Fèb. 24, 2004); see also supra notes $172-87$ and accompanying text. 
make environmental protection more data-driven, empirically grounded, and analytically rigorous. And heightened transparency will draw new participants into environmental decisionmaking and democratize the policy process.

These advances create the foundation for an. Information Age environmental revolution which will transform the optimal mix of institutional solutions to environmental problems. In an informationrich world, a property rights approach to the environment becomes more attractive. The same technological advances will make it easier for regulators to harness market forces and use economic incentivebased regulatory tools more broadly. The data dissemination power of the Internet could well result in the development of stronger environmental stewardship norms, which could change the social context for environmental policymaking. But even where command-and-control regulation persists, a more information-intensive approach to environmental protection will make it easier to refine policy choices, manage complexity, and tolerate diversity.

Lower cost information will allow us to rethink the ends as well as the means of environmental protection. As individual property rights become easier to delineate and protect, the cost of making corrective justice a policy goal goes down. And to the extent that environmental problems arise from direct information failures-mistakes, inefficiency, or waste-special opportunities to improve resource productivity and to identify and adopt "best practices" in both production and consumption are likely to emerge. Similarly, information disclosure strategies may permit a decollectivization of analysis and decisionmaking, facilitating a shift toward individual choice where externalities are not the central issue.

Just as information availability affects institutional design, so too does institutional design affect the quantity and quality of data available for environmental decisionmaking. Our current regulatory regime needs to be rethought with an eye toward incentives for the generation and dissemination of data, analysis, and knowledge. Given persistent market failures in this regard, some element of government investment in environmental information is likely to be justified.

Divergent underlying values and the need for political judgment will continue to make environmental policymaking contentious. The technological breakthroughs of the Information Age are not, therefore, a panacea. The new tools and the institutional refinements that they make possible offer the prospect of reduced information gaps and an environmental protection regime that is more data-driven, refined, individualized, and efficient. But the precise contours of the path toward Information Age environmental protection are not well 
defined. The analysis in this Article must, therefore, be seen only as a first step toward the promise of Information Age environmental policy. Legislators, policymakers, judges, scholars, businesses, consumers, and citizens will have to do significant work to turn the promise into a reality. 